\title{
Recent Advances in Biochar Engineering for Soil Contaminated with Complex Chemical Mixtures: Remediation Strategies and Future Perspectives
}

Jerry Anae', Nafees Ahmad ${ }^{1,4}$, Vinod Kumar', Vijay Kumar Thakur ${ }^{2}$, Tony Gutierrez ${ }^{3}$, Xiao Jin Yang ${ }^{5,6}$, Chao $\mathrm{Cai}^{7}$, Zhugen Yang ${ }^{1}$ and Frederic Coulon ${ }^{1}$

${ }^{1}$ School of Water, Energy and Environment, Cranfield University, Cranfield, MK43 0AL, UK

${ }^{2}$ Biorefining and Advanced Materials Research Centre, Scotland's Rural College, Edinburgh, EH9 3JG, UK

${ }^{3}$ Institute of Mechanical, Process and Energy Engineering (IMPEE), School of Engineering and Physical Sciences, Heriot-Watt University, Edinburgh, EH14 4AS, UK

${ }^{4}$ Environmental Research Laboratory, Department of Chemistry, Aligarh Muslim University, Aligarh, 202002, India

${ }^{5}$ State Key Laboratory of Chemical Resource Engineering, Beijing Advanced Innovation Center for Soft Matter Science and Engineering, Beijing University of Chemical Technology, Beijing 100029, China

${ }^{6}$ State Key Laboratory of Organic-Inorganic Composites, Beijing University of Chemical Technology, Beijing, 100029, PR China

${ }^{7}$ Key Lab of Urban Environment and Health, Institute of Urban Environment, Chinese Academy of Sciences, Xiamen, 361021, China

\section{Abstract}

Heavy metal/metalloids (HMs) and polycyclic aromatic hydrocarbons (PAHs) in soil have caused serious environmental problems, compromised agriculture quality, and have detrimental effects on all forms of life including humans. There is a need to develop appropriate and effective remediation methods to resolve combined contaminated problems. Although conventional technologies exist to tackle contaminated soils, application of biochar as an effective renewable adsorbent for enhanced bioremediation is considered by many scientific researchers as a promising strategy to mitigate HM/PAH co-contaminated soils. This review aims to: (i) provide an overview of biochar preparation and its application, and (ii) critically discuss and examine the prospects of (bio)engineered biochar for enhancing HMs/PAHs co-remediation efficacy by reducing their mobility and bioavailability. The adsorption effectiveness of a biochar largely depends on the type of biomass material, carbonisation method and pyrolysis conditions. Biochar induced soil immobilise and remove metal ions via various mechanisms including electrostatic attractions, ion exchange, complexation and precipitation. PAHs 
remediation mechanisms is achieved via pore filling, hydrophobic effect, electrostatic attraction, hydrogen bond and partitioning. During last decade, biochar engineering (modification) via biological and chemical approaches to enhance contaminant removal efficiency has garnered greater interests. Hence, the development and application of (bio)engineered biochars in risk management, contaminant management associated with $\mathrm{HM} / \mathrm{PAH}$ co-contaminated soil. In terms of (bio)engineered biochar, we review the prospects of amalgamating biochar with hydrogel, digestate and bioaugmentation to produce biochar composites

Keywords: Contaminated soil, biochar, (bio)engineering, hydrogel, digestate, bioaugmentation 


\section{Table of Contents}

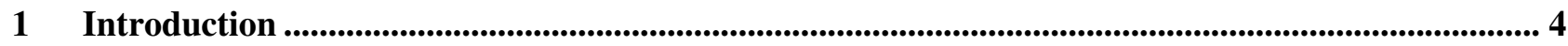

1.1 Soil Contamination: A vital Life Supporting Resource..................................................................... 4

1.2 Heavy Metal Classification and Mechanism of Toxicity ................................................................ 4

1.3 Polycyclic Aromatic Hydrocarbon Classification and Mechanism of Toxicity ............................... 5

2 A Need for Integrated Engineered Remediation Approaches .................................................................... 11

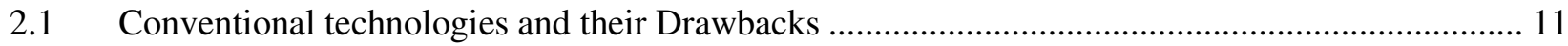

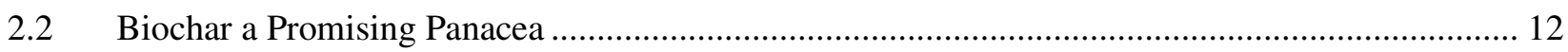

2.3 Biochar Production, Properties and Applications.................................................................... 17

2.4 Engineered Modification of Biochar for Tailored and Enhanced Remediation Approaches .......... 23

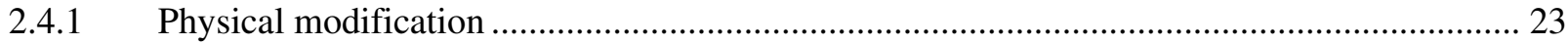

2.4.2 Biological modification (bioengineered biochar) ................................................................ 23

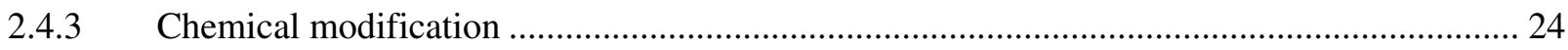

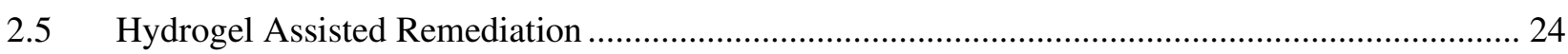

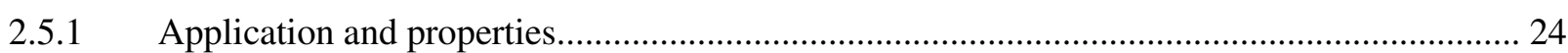

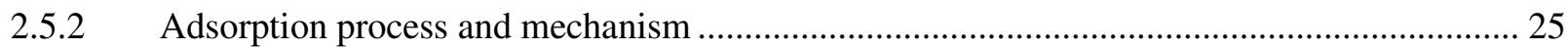

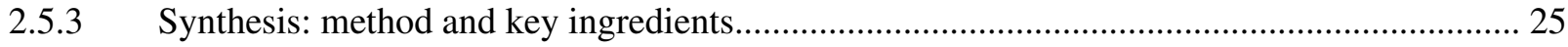

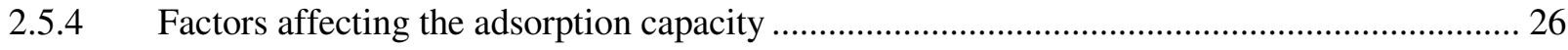

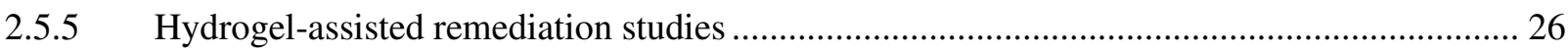

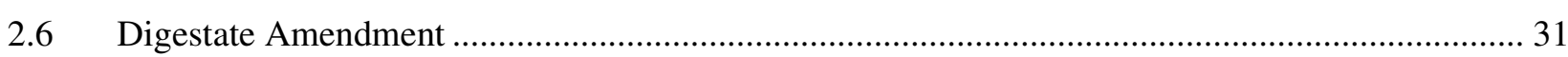

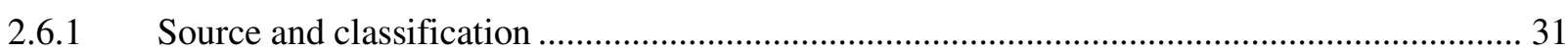

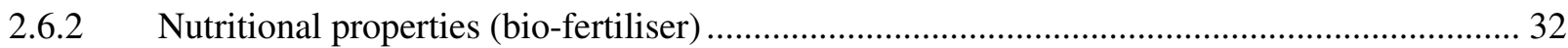

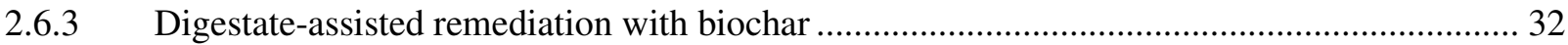

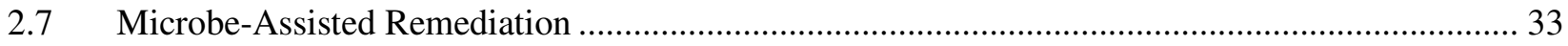

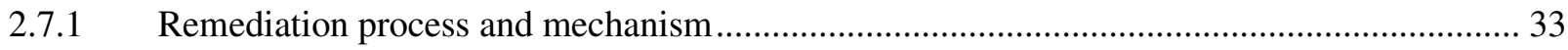

2.7.2 Bactoremediation, mycoremediation and phycoremediation ................................................ 34

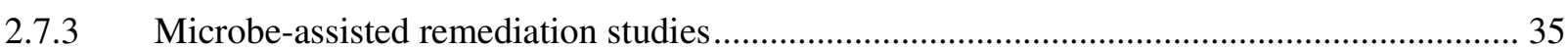

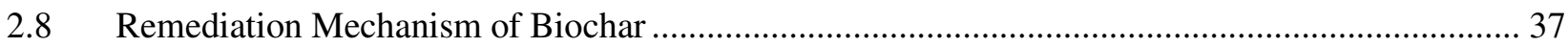

3 Biochar/Digestate-Based Circular Bioeconomy ................................................................................................ 42

$4 \quad$ Large-Scale Filed Application and Challenges ..........................................................................................4 43

5 Conclusion and Future Perspectives........................................................................................................................ 44

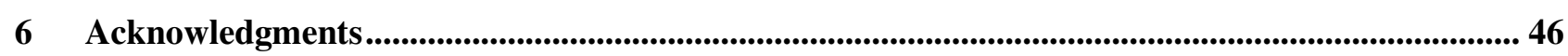

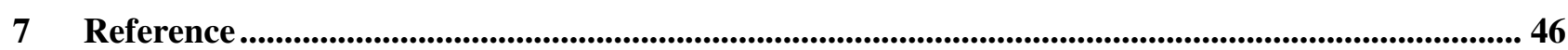




\section{Introduction}

\subsection{Soil Contamination: A vital Life Supporting Resource}

For generations, soil continues to be the foundation on which humans' source $90 \%$ of their food, livestock feed, fibre and fuel. It provides raw materials and groundwater. It also serves as a water purifier and habitat for billions of living organisms, including humans (Gentile, 2000). Hence, soils are critical resources for achieving many of the 17 identified United Nation Sustainable Development (UNSDP) Goals, including food security, clean water, improve sanitation, and good health and wellbeing. In the last few decades, the exponential increase in human population and a substantial increase in industrialisation and urbanisation have resulted in the pollution of practically every environment on Earth, including soil (Ali et al., 2019; Tang et al., 2014). Typical soil pollutants include polycyclic aromatic hydrocarbons (PAHs), crude oil and its petrochemical derivatives, heavy metal/metalloids (HMs), pesticides, herbicides and chlorophenols (Chen et al., 2015). Among these pollutants, HMs and PAHs pose serious threats to food security and exert detrimental effects on human health and ecosystems (Perez et al., 2010). This is largely due to their toxicity, persistence and potential to bioaccumulate, and with respect to HMs their non-biodegradability properties (Hadia-eFatima, 2018).

\subsection{Heavy Metal Classification and underlying Mechanism for their Toxicity}

HMs can be divided into macro-nutrient (e.g. Co and $\mathrm{Mg}$ ), micro-nutrient (e.g. $\mathrm{Cu}, \mathrm{Ni}, \mathrm{Fe}, \mathrm{Mn}$ and $\mathrm{Mb}$ ) elements, and those that are highly toxic (e.g. $\mathrm{Hg}, \mathrm{Cr}, \mathrm{Cd}, \mathrm{Pb}, \mathrm{Ag}, \mathrm{Pd}, \mathrm{Bs}, \mathrm{As}, \mathrm{Se}, \mathrm{Sn}$ and $\mathrm{Zn}$ ) (Selvi et al., 2019). Macro and micro-nutrient elements are also referred to as essential elements which are beneficial to the growth, development and reproduction of plants, but can be harmful when present in excessive quantities (Whitfield et al., 2010). Conversely, highly toxic elements can be harmful at trivial concentrations (Sall et al., 2020). Toxicity effects of HMs vary based on the specific $\mathrm{HM}$ ion species and the individual organisms that are exposed. However, the generation of free radicals is considered by many researchers as the common mechanism of HM toxicity, particularly in humans, which can cause oxidative stress, damage of biological molecules such as enzymes, 
proteins, lipids, and nucleic acids (Engwa et al., 2019). Damage to DNA is a key process leading to carcinogenesis and neurotoxicity (Lu et al., 2015).

\subsection{Polycyclic Aromatic Hydrocarbon Classification and Mechanism of Toxicity}

In terms of PAHs, the 16 United States Environmental Protection Agency (USEPA) priority PAHs have been accepted as a representative and standardised set of compounds and were used extensively in environmental and analytical science in the last 50 years. But recently, there is a growing call to add additional compounds to this list. Compounds such as heterocyclic compounds, oxy-PAHs and nitro-PAHs (Pulleyblank et al., 2019; Andersson and Achten, 2015). One of the main reasons for this is to include these types of additional PAHs compounds that are of considerably higher toxicity than those currently present in the USEPA priority list (Andersson and Achten, 2015). From the many types of PAHs, some of the widely spread and commonly studied include naphthalene (Nap), anthracene (Ant), phenanthrene (Phe), pyrene (Pyr), chrysene (Chr), benzo[a]anthracene (B[a]A), fluoranthene $(\mathrm{Flu})$, benzo[b]fluoranthene $(\mathrm{B}[\mathrm{b}] \mathrm{F})$, benzo[k]fluoranthene $(\mathrm{B}[\mathrm{k}] \mathrm{F})$, benzo[a]pyrene $(\mathrm{B}[\mathrm{a}] \mathrm{P})$, dibenz[a,h]anthracene $(\mathrm{D}[\mathrm{a}, \mathrm{h}] \mathrm{A})$ and indeno[1,2,3-c,d]pyrene (I[c,d]P) (Pulleyblank et al., 2019; Bianco et al., 2020; Adel-Shafy et al., 2016). Generally, individual PAH compound is classisfied based on geno-toxic and carcinogenicity. According to International Agency for Research on Cancer-IARC (1983; 2010), PAHs are classified as carcinogenic to humans (Group 1), probably carcinogenic to humans (Group 2A), or possibly carcinogenic to humans (2B). Two-ringed PAHs, and to a lesser extent three-ringed PAHs, dissolve in water, making them more available for biological uptake and degradation (Choi et al., 2010; Johnsen et al., 2005). Further, two and three-ringed PAHs including some four-ringed PAHs depending on temperature can easily volatilise as gaseous into the atmosphere (Atkinson and Arey, 1994; Srogi, 2007). In contrast, compounds with four and five or more rings also referred to as High Molecular Weight PAHs (HMWPAHs) have low solubility in water and low volatility; they are therefore predominantly in solid-state, bound to soil and organic matter (Choi et al., 2010). In solid-state, these compounds are less accessible for biological uptake or degradation, which increases their persistence in the environment, and making them more detrimental 
to the environment and human health (Johnson et al., 2005; Haritash and Kaushik, 2009; Xu et la., 2020). It is well-documented that the HMWPAHs are difficult to degrade, and they can be more detrimental to the environment and human health (Xu et al., 2020). Of all the HMWPAHs, B[a]P is considered the most toxic of the parent PAHs, common PAH to cause cancer in animals including humans and is widely used as a key marker PAH for environmental assessments (Cave et al., 2010; Latif et al., 2010).

Not all PAHs are carcinogenic. In fact, two and three-ringed (Lower Molecular Weight-LMW) PAHs have lower toxic equivalent factors and are non-carcinogens compared to HMWPAHs (Wu et al., 2019). The IARC Monographs Programme has reviewed experimental data for 60 individual PAHs (IARC, 2010). Of these 60 PAHs reviewed and with reference to the list of commonly widespread and studied PAHs mentioned above, one, B[a]P, is classified as carcinogenic to humans (Group 1). $\mathrm{D}[\mathrm{a}, \mathrm{h}] \mathrm{A}$ is classified as probably carcinogenic to humans (Group 2A), and B[a]A, B [b]F, B [k]F, Chr and I[c,d]P are classified as possibly carcinogenic to humans (Group 2B). The toxicity mechanism of PAHs mainly affects the function of cellular membranes and enzyme systems which are associated with membranes (Zhang et al., 2019). The mechanism of PAH-induced carcinogenesis is believed to be via the binding of PAH metabolites to DNA (Zhang et al., 2019; Barnes et al., 2018). Briefly, PAHs are transported into cells due to their hydrophobicity characteristic. Once inside the cells, PAHs induce phase I and II gene expressions of cytochrome P450 (CYP) monooxygenase enzyme and an enzyme II (e.g. glutathione s-transferase) via aryl hydrocarbon receptor leading to the metabolism of PAHs into various metabolites or active carcinogens such as diol-epoxides and radical cations which can bind to DNA (DNA adduct) and become mutagenic or carcinogenic (Moorthy et al., 2015; Honda and Suzuki, 2020).

Generally, the toxicity of both pollutants (HMs and PAHs) depends on the absorbed dose, the route of exposure and duration of exposure (i.e. chronic or acute), which can lead to various effects and disorders (Jaishankar et al., 2014). Table 1 below shows various anthropogenic activities contributing to the release of HMs/PAHs into the environment and summarises the toxic effects of the various 
pollutants to plants, soil microorganisms and humans. But the common anthropogenic sources of HMs/PAHs originate from mining, petroleum, agriculture and chemical industries and other operations. While HMs and PAHs in the soil environment originate from natural geological processes (Dixit et al., 2015; Gutierrez, 2019), significant amount stems from anthropogenic sources (Cristaldi et al., 2017). 
Table 1. Detrimental effects of highly toxic HMs and carcinogenic PAHs (commonly widespread and studied) to living organisms

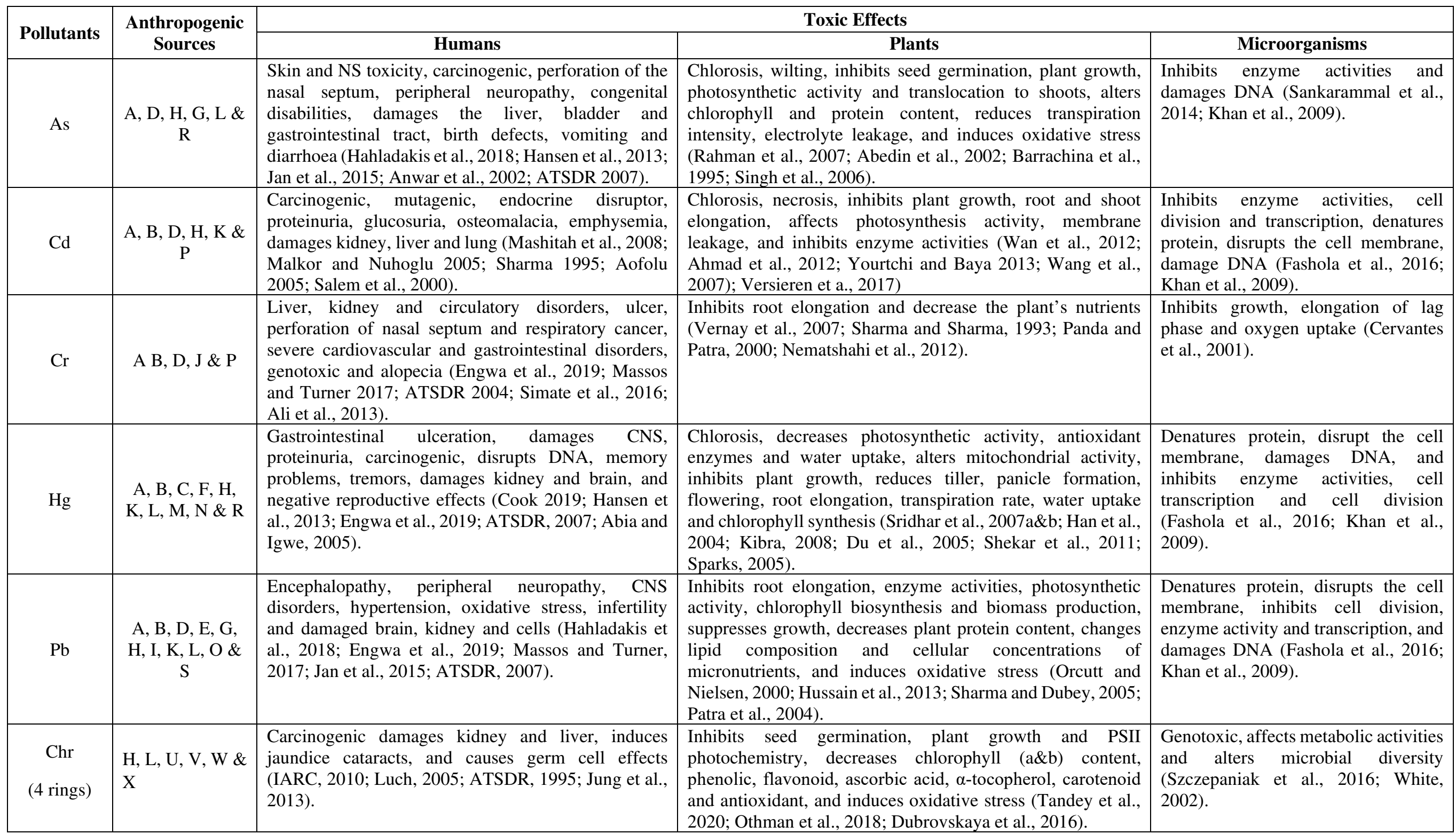




\begin{tabular}{|c|c|c|c|c|}
\hline $\begin{array}{l}\mathrm{B}[\mathrm{a}] \mathrm{A} \\
(4 \text { rings })\end{array}$ & $\begin{array}{l}\mathrm{H}, \mathrm{L}, \mathrm{U}, \mathrm{V}, \mathrm{W} \& \\
\mathrm{X}\end{array}$ & $\begin{array}{l}\text { Carcinogenic affects the nervous system and fertility, } \\
\text { causes heart malformation, childhood asthma and skin } \\
\text { irritations, and leads to embryotoxic effects (IARC, } \\
\text { 2010; PHE, 2018; Igwe and Ukaogo, 2015; Luch, } \\
\text { 2005; Wassenberg and Di-Giulio, 2004). }\end{array}$ & $\begin{array}{l}\text { Inhibits plant growth and PSII photochemistry, decreases } \\
\text { chlorophyll (a\&b) content, phenolic, flavonoid, ascorbic acid, } \\
\alpha \text {-tocopherol, carotenoid and antioxidant, and induces } \\
\text { oxidative stress (Tandey et al., 2020; Othman et al., 2018). }\end{array}$ & $\begin{array}{l}\text { Affects metabolic activities, alters } \\
\text { microbial diversity, damages cell wall } \\
\text { disrupts membrane activities, and } \\
\text { interferes with protein and enzymatic } \\
\text { activities (Broniatowski et al., 2017; } \\
\text { Abdel-Shafy and Mansour, 2016; } \\
\text { Szczepaniak et al., 2016). }\end{array}$ \\
\hline $\begin{array}{c}\mathrm{B}[\mathrm{b}] \mathrm{F} \\
(5 \text { rings })\end{array}$ & $\begin{array}{l}\mathrm{H}, \mathrm{L}, \mathrm{U}, \mathrm{V}, \mathrm{W} \& \\
\mathrm{X}\end{array}$ & $\begin{array}{l}\text { Carcinogenic, and causes eye irritation, nausea, } \\
\text { vomiting and diarrhoea (IARC, 2010; Lawal, 2017). }\end{array}$ & $\begin{array}{l}\text { Inhibits plant growth and PSII photochemistry, decreases } \\
\text { chlorophyll (a\&b) content, phenolic, flavonoid, ascorbic acid, } \\
\text { a-tocopherol, carotenoid and antioxidant, and induces } \\
\text { oxidative stress (Tandey et al., 2020; Othman et al., 2018). }\end{array}$ & $\begin{array}{l}\text { Affects metabolic activities, alters } \\
\text { microbial diversity, interferes with } \\
\text { protein and enzymatic activities } \\
\text { (Abdel-Shafy and Mansour, 2016; } \\
\text { Szczepaniak et al., 2016). }\end{array}$ \\
\hline $\begin{array}{c}\mathrm{B}[\mathrm{k}] \mathrm{F} \\
(5 \text { rings })\end{array}$ & $\begin{array}{l}\mathrm{H}, \mathrm{L}, \mathrm{U}, \mathrm{V}, \mathrm{W} \& \\
\mathrm{X}\end{array}$ & $\begin{array}{l}\text { Carcinogenic, and causes tumours of the } \\
\text { gastrointestinal tract and lungs (IARC, 2010; ATSDR, } \\
\text { 1995). }\end{array}$ & $\begin{array}{l}\text { Inhibits plant growth and PSII photochemistry, decreases } \\
\text { chlorophyll (a\&b) content, phenolic, flavonoid, ascorbic acid, } \\
\alpha \text {-tocopherol, carotenoid and antioxidant, and induces } \\
\text { oxidative stress (Tandey et al., 2020; Othman et al., 2018) }\end{array}$ & $\begin{array}{l}\text { Affects metabolic activities and alters } \\
\text { microbial diversity (Szczepaniak et } \\
\text { al., 2016) }\end{array}$ \\
\hline $\begin{array}{c}\mathrm{B}[\mathrm{a}] \mathrm{P} \\
(5 \text { rings })\end{array}$ & $\begin{array}{l}\mathrm{H}, \mathrm{L}, \mathrm{U}, \mathrm{V}, \mathrm{W} \& \\
\mathrm{X}\end{array}$ & $\begin{array}{l}\text { Carcinogenic, mutagenic and teratogenic, induces } \\
\text { apoptosis of CD34+ stem cells, affects immune } \\
\text { response, causes birth defects, leukaemia, heart } \\
\text { malformation, childhood asthma, nausea, diarrhoea } \\
\text { and DNA adduct, embryotoxic effects, and a skin } \\
\text { irritant and sensitiser (IARC, 2010; Lawal, 2017; } \\
\text { Luch, 2005; ATSDR, 1995; Giri et al., 2016); } \\
\text { (Wassenberg and Di-Giulio, 2004; van Grevenynghe, } \\
\text { 2005). }\end{array}$ & $\begin{array}{l}\text { Affects membrane permeability and photosynthesis causes } \\
\text { enzymatic dysfunction, decreases chlorophyll (a\&b) content, } \\
\text { phenolic, flavonoid, ascorbic acid, } \alpha \text {-tocopherol, carotenoid } \\
\text { and antioxidant, and induces oxidative stress (Tandey et al., } \\
\text { 2020; Duxbury et al., 1997). }\end{array}$ & $\begin{array}{l}\text { Genotoxic, affects metabolic activities } \\
\text { and microbial diversity, damages } \\
\text { DNA and interferes with protein and } \\
\text { enzymatic activities (Abdel-Shafy and } \\
\text { Mansour, 2016; Szczepaniak et al., } \\
\text { 2016; Sowada et al., 2017; White, } \\
\text { 2002). }\end{array}$ \\
\hline $\begin{array}{l}\mathrm{D}[\mathrm{a}, \mathrm{h}] \mathrm{A} \\
(5 \text { rings })\end{array}$ & $\begin{array}{l}\mathrm{H}, \mathrm{L}, \mathrm{U}, \mathrm{V}, \mathrm{W} \& \\
\mathrm{X}\end{array}$ & $\begin{array}{l}\text { Carcinogenic causes cataracts and jaundice cataracts } \\
\text { and damages kidney and liver (IARC, 2010; ATSDR, } \\
\text { 1995; Giri et al., 2016). }\end{array}$ & $\begin{array}{l}\text { Decreases chlorophyll (a\&b) content, phenolic, flavonoid, } \\
\text { ascorbic acid, } \alpha \text {-tocopherol, carotenoid and antioxidant, and } \\
\text { induces oxidative stress (Tandey et al., 2020). }\end{array}$ & $\begin{array}{l}\text { Damages cell wall, disrupts } \\
\text { membrane activities and interferes } \\
\text { with protein and enzymatic activities } \\
\text { (Abdel-Shafy and Mansour, 2016; } \\
\text { Broniatowski et al., 2017). }\end{array}$ \\
\hline $\begin{array}{l}\mathrm{I}[\mathrm{c}, \mathrm{d}] \mathrm{P} \\
(6 \text { rings })\end{array}$ & $\begin{array}{l}\mathrm{H}, \mathrm{L}, \mathrm{U}, \mathrm{V}, \mathrm{W} \& \\
\mathrm{X}\end{array}$ & $\begin{array}{l}\text { Carcinogenic, and induces jaundice cataracts (IARC, } \\
\text { 2010; ATSDR, 1995). }\end{array}$ & $\begin{array}{l}\text { Inhibits plant growth and PSII photochemistry (Othman et al., } \\
\text { 2018). }\end{array}$ & $\begin{array}{l}\text { Damages cell wall, disrupts } \\
\text { membrane activities and interferes } \\
\text { with protein and enzymatic activities } \\
\text { (Abdel-Shafy and Mansour, 2016; } \\
\text { Broniatowski et al., 2017). }\end{array}$ \\
\hline \multirow{4}{*}{\multicolumn{2}{|c|}{$\begin{array}{ll}\text { A } & \text { Mining industries } \\
\text { B } & \text { Metallurgy/metal plating } \\
\text { C } & \text { Chemical industries } \\
\text { D } & \text { Dyes/paints/pigments }\end{array}$}} & E & & $\begin{array}{lll}\text { retardants } & \text { V } & \text { Sewage sludge } \\
\end{array}$ \\
\hline & & Pharmaceuticals & $\mathrm{R}$ Electrical/elec & Combustion proce \\
\hline & & Textiles & S Welding/solde & Mobile sources \\
\hline & & H Fertilizers/biocides & P Galvanised pipe/corrosion & \\
\hline
\end{tabular}


Also, Table 1 shows the typical toxicity effects of HMs/PAHs on microorganisms which include disruption of cellular function and metabolic activities, oxidative stress, inhibition of enzyme activities, and damage of DNA. In the case of plants, chlorosis, necrosis, plant growth diminution, inhibition of enzyme activities, decreased chlorophyll, and inhibition of photosynthesis process and photosystem II activities are all common. Humans mostly suffer from HMs/PAHs toxicity by carcinogenic and mutagenic effects of the pollutants, including damage to important organs such as the liver, kidney, lung and brain.

HMs and PAHs are also capable of interacting with other naturally occurring inorganic compounds in soil that can form into toxic by-products with carcinogenic or mutagenic properties (Singh et al., 2017). Therefore, it is necessary to ascertain their bioavailable concentrations, exposure and potential toxicity in soil ecosystems which require suitable remediation strategies to effectively control these pollutants. While methods exist to remediate and control these pollutants, lately more attention has been directed towards the development of sustainably low-cost, environmentally friendly and effective remediation strategies. One such technology that has garnered increased interest is the application of biochar, particularly in environmental engineering. Biochar is a carbonaceous, solid and recalcitrant compound derived from the pyrolysis of waste biomass (Pandey et al., 2020). Most of the review articles published to date mainly focused on the sole application of biochar for the remediation of both or either HM ions and/or PAHs (e.g. Abbas et al., 2018; M. Guo et al., 2020; X. Guo et al., 2020 Cheng et al., 2020). Others have reviewed the potential of combining biochar with either digestate or bioaugmentation (e.g. B. Wang et al., 2017; Panahi et al., 2020). To the best of our knowledge, this review is the first of this kind that summarises the prospect of amalgamating biochar with hydrogel, digestate and bioaugmentation to enhancing remediation of co-contaminated (HMs and PAHs) soil. Herein, we review the remediation efficiency of biochar and engineered biochar. We also included remediation mechanisms of selected promising extraction techniques, as well as discuss its advantages and limitations. These techniques, in combination with biochar to enhance its remediation efficiency, are also discussed. Whilst biochar shows great promise for the remediation 
of soil contaminated with HMs and/or PAHs, a view to its future success in this respect must take into account several important facets, concepts and knowledge gaps, such as (1) understanding the sorption mechanism of biochar and factors affecting its adsorption properties, particularly physicochemical factors, (2) implementing effective integrated (bio)engineered remediation approaches to enhance remediation efficacy of biochar, (3) understanding the pollutant removal mechanisms of the hydrogel, digestate and bioaugmentation, respectively, including factors influencing the remediation properties of the individual method, (4) promote environmentally friendly and sustainable approaches that embrace the circular bioeconomy concept, and (5) explore the applicability of (bio)engineered remediation strategies at regulatory and industry level.

\section{A Need for Integrated Engineered Remediation Approaches}

\subsection{Conventional technologies and their Drawbacks}

Existing conventional physical treatment (thermal treatment and soil replacement), chemical (leaching, precipitation, ion exchange and immobilisation) and physicochemical technologies (electro-kinetics, vitrification and soil washing) have proven, to some extent, effective in removing HMs and PAHs from contaminated soils (Sharma et al., 2018; Qayyum et al., 2020). Nevertheless, these technologies remain jeopardized by some minor and major shortcomings. This include poor feasibility, inefficiency, high cost, unsustainability and high secondary risk (Khalid et al., 2017; Lahori et al., 2017; Cao et al., 2004). Other existing technologies can also compromise soil quality (Khalid et al., 2017), can cause loss of other valuable metals (Tripp et al. 2002; Hou and Gao, 2003), or can only be effective under certain conditions such as low soil permeability and low carbonate conditions (Hanson et al. 1992). Other methods such as stabilization and solidification (S/S) and encapsulation can only stabilise and entrap pollutants in a solid form but does not destroy, transform or remove pollutants (Khalid et al., 2017) which are desirable outcomes for a successful remediation. Conversely, biological remediation (bioremediation) is often more economical and environmentally friendly, and as such has attracted increased interest in recent years. However, bioremediation 
methods also have their limitations, for example, phytoremediation requires hyperaccumulators which are mostly quite slow-growing and, hence, their pollutant-accumulating rate is also slow. Hyperaccumulators are plant species with the ability to grow on contaminated soil and accumulate extraordinarily high concentrations of chemical contaminants, such as HMs and PAHs, without suffering phytotoxic effects compared to the majority of species (Rascio and Navari-Izzo, 2011). In addition, the use of invasive hyperaccumulator species can be a threat to native biodiversity (Chibuike and Obiora, 2014).

\subsection{Biochar: A Promising Panacea}

Other biological methods or materials (e.g. biochar), digestate and bioaugmentation have shown promising potential in the bioremediation of HMs and PAHs as has been demonstrated in laboratoryscale experiments (Tables 2 and 3). However, there are limited field and industrial applications that have been conducted to ascertain the feasibility and viability of these methods in the natural environment. Few field studies conducted so far which involve the application of biochar for removal of HMs and PAHs have shown promising results. For example, biochar treatment greatly reduced Cd content in rice grain by $20-90 \%$, resulting in a safe Cd level $(<0.4 \mathrm{mg} / \mathrm{kg})$ of rice grain from all Cdcontaminated rice fields at a biochar dosage of 40 t/ha (Bian et al., 2013). Another field study revealed exchangeable $\mathrm{Cd}$ decreased by $8.5 \%$ and bioavailability of $\mathrm{HMs}(\mathrm{Cd}, \mathrm{Cu}$ and $\mathrm{Pb})$ to plant shoots and roots were significantly reduced with increasing sugarcane bagasse biochar application rate (Nie et al., 2018). Biochar significantly reduced $\mathrm{Cd}$ and $\mathrm{Zn}$ availability by up to $85 \%$ and $91 \%$, respectively, in an acidic paddy soil when incorporated at a rate of 20 and 40 t/ha (Chen et al., 2016). Similarly, a field experiment showed biochar increased the content of available nutrients in soils and decreased the content of exchangeable $\mathrm{Pb}$ in soils and biomass in above-ground parts of maize plants and grains; decreased the Cd contents in maize stems and grains by $27 \%$ and $25 \%$, respectively; and decreased the $\mathrm{Pb}$ content in roots by $16 \%$ (Zhan et al., 2019). A 6 months mesocosm scale study by Cippulo et al., (2018) amended genuine PAHs contaminated soil with $5 \%$ w/w biochar (soil + biochar). The result showed TPH total content decreased by $18 \%$ and bioavailable concentration decreased by $24-$ 
$28 \%$. In another study, the PAH sorptive efficiency of biochar was investigated in a five-years field experiment which involved biochar treatments of $16.5 \mathrm{t} / \mathrm{ha}$ of biochar application dosage in 2010 . Thereafter, PAHs concentration decreased significantly with time from $153 \pm 38 \mathrm{ng} / \mathrm{g}$ at first sampling to $80 \pm 12$ ng/g (Rombola et al., 2019). Stefanuik et al., (2017) experimented the removal of total PAHs ( 1 16USEPA PAH) by $2.5 \%$ biochar application rate on podzolic soil in an 18 months field experiment. After 12 months, up to $45 \%$ reduction in $\Sigma 16$ PAHs concentrations in soil was recorded. Another field experiment with soil amended with $2.5 \%$ biochar over an 18 months incubation period reported a maximum reduction of 4-6 rings PAHs by 18-67 \% (Oleszczuk et al., 2019).

In most cases, the production of conventional biochars via pyrolysis has a relatively low surface area with subsequent low adsorption capacity (Rajapaksha et al. 2016). Purposive tailoring of their physicochemical properties can enhance their effectiveness in engineering applications (Rajapaksha et al. 2016). Biochar tailoring is also known as biochar modification. Massively produced biochars and their modified products are also referred to as engineered biochars (Duan et al., 2019). Engineering or modification of biochar (derived from biological feedstock materials) using applications of biological principles and engineering tools can be referred to as bioengineered biochars. Hence, a strategy is to integrate different methods to address some of the drawbacks associated with individual method whilst enhancing their remediation performance. For example, a promising strategy could be in integrating biological and chemical techniques, such as via the amalgamation of biochar with hydrogel, digestate and bioaugmentation to produce modified biochar composite or engineered biochars as demonstrated in Figure 1 below. Each of these remediation agents or methodologies involves various combinations of remediation mechanisms to remove HMs and PAHs, which are summarised in Table 4. Several researchers have classified biochar remediation techniques as either, or a combination, of chemical, physical and physicochemical methods depending on how each researcher understands the mechanism of the biochar-mediated remediation process. 
depending on the type of biochar, post-treatment measures, aging conditions, type of carbonisation method utilised, and specific pyrolysis conditions employed (Buss et al., 2015; Oleszczuk and Kołtowski, 2018). For example, Buss et al., (2016) concluded that straw-derived biochar contained 5.8 times higher PAH concentrations than softwood-derived biochar, and PAH concentration significantly decreased in case of straw-derived biochar (43 $\mathrm{mg} \mathrm{kg}^{-1}$ to $4 \mathrm{mg} \mathrm{kg}^{-1}$ ) when carriers gas flow of pyrolysis reactor was increased.

Table 2 and 3 show some recent lab-scale applications of biochar and HMs/PAHs decontamination efficiency. It also highlights key advantages of biochar as a bioadsorbent for enhancing remediation applications. It acts as a soil conditioner by improving soil quality, soil fertility and microbial activity (Wang et al., 2018; Safaei et al., 2018). Since biochar can also sequester greenhouse gases, such as $\mathrm{CO}_{2}, \mathrm{CH}_{4}$ and $\mathrm{N}_{2} \mathrm{O}$, it could have a significant role in climate change mitigation if biochar production, such as for bioremediation, were to become more widely applied worldwide (Matuštík et al., 2020; Dissanayake et al., 2020). Figure 2 below shows the reuse of various agricultural biomass wastes as feedstock materials to promote sustainability and cost-effective strategy, production of biochar and illustrates the four main applications of biochar.

Previous studies have shown that remediation using hydrogel, digestate and bioaugmentation are effective in removing HMs and PAHs when used individually (Table 2 and 4) owing to individual remediation mechanisms presented in Table 4. However, more work is needed to acquire a better understanding on the remediation efficiency and potential of amalgamating biochar with each of the aforementioned remediation agents and to evaluate their synergistic effects on the behaviour of pollutants and their bioavailability. The few adsorption studies conducted so far have shown promising results. For example, a biochar-hydrogel composite with 5\% biochar was shown to significantly increase the swelling ratio of the hydrogel to $1506 \%$, which is almost twice the size of the untreated hydrogel (818\%), demonstrating great potential for the removal of Cd from soil (Li and Chen, 2018). Application of a biochar-digestate composite improved removal efficiency of $\mathrm{Pb}$ by nearly $100 \%$ when the composite dosage was applied at $1 \mathrm{~g} \mathrm{~L}^{-1}$. The same trend was observed for $\mathrm{Cd}$ 
in this dosage range, where the removal percentage increased from $13 \%$ to nearly $100 \%$ (Chen et al., 2019a). The digestate used in this study was prepared by anaerobic digestion of food waste and the biochar was prepared by pyrolysis of digestate granules at $700{ }^{\circ} \mathrm{C}$ for 15 minutes. Another study used a combination of maize biochar and bacterial strain Pseudomonas sp. NT-2 (biochar-microbe composite) to investigate the dynamic effects and potential mechanisms of biochar alone and bacterialoaded biochar on the immobilization of both $\mathrm{Cd}$ and $\mathrm{Cu}$ in soil by a 75-day pot experiment. Compared to the single biochar amendment, the results showed that the application of biochar inoculated with strain NT-2 significantly increased the proportion of total fraction of $\mathrm{Cd}$ and $\mathrm{Cu}$, thus reducing the bioavailability of these metal ions in the soil. The application of bacterial-loaded biochar has also been shown to markedly enhance soil urease and catalase activities, and improved soil microbial community at the end of incubation indicating a recovery of soil function following metal stabilization (Tu et al., 2020).

Nonetheless, all these studies determined total concentrations of the contaminants rather than the bioavailable fraction. Bioavailability is defined as the fraction of freely available contaminant in the environment that is mobile and thus most likely to lead to human exposure (Dean and Scott, 2004). It influences the exposure of humans and ecological receptors to chemicals in soils, and because exposure is one aspect of risk assessment, measuring or modelling bioavailability is important for risk assessment and management of contaminated land. A similar trend is also observed in many other studies which employ total concentration of contaminants for risk assessment and management of contaminated land, as well as exposure risks. Total concentration does not address partitioning and associated toxicological effects of the partitioned fractions, such as the bioavailable fraction, and therefore can be misleading in terms of risk assessment and contaminant management (Cipullo et al., 2019). Table 2 below shows some main advantages and advantages of using biochar, hydrogel, digestate and bioaugmentation for remediation purposes. By nature of their bio-based genesis and composition, these remediation methods are deemed eco-friendly, economical and sustainable approaches for application to bioremediation. 


\subsection{Biochar Production, Properties and Applications}

Biochar can be prepared using various methods. Some of these methods include pyrolysis, hydrothermal carbonization, microwave carbonization, flash carbonization, gasification, torrefaction, laser and plasma cracking (Liu et al., 2013; Xie et al., 2015). Pyrolysis, gasification and hydrothermal carbonisation are the common methods for biochar preparation (Wang and Wang, 2019). However, pyrolysis has been the go-to method because it is simple to operate, cost-effective and requires less energy compared to the other methods (Maguyon-Detras et al., 2020; L. Wang et al., 2020; X. Wang et al., 2020). Also, little data is available for carbonization (hydrothermal, microwave and flash), torrefaction and gasification as these technologies are commonly favoured for bio-oil, solid fuel or synthetic gas yield (Tomczyk et al. 2020; Biogreen, 2020). With respect to the pyrolysis method, biochars are produced under high temperature (typically between $350-800{ }^{\circ} \mathrm{C}$ ) and in an inert atmosphere free of oxygen (Varma et al., 2018). The recent trend of pyrolysis studies is geared towards the development of new pyrolysis methods and modification of conventional pyrolysis methods. The primary aim is to synthesise engineered biochars with the excellent performance or to improve certain physicochemical properties of biochar, or to reduce the risks associated with the utilisation of contaminated biomass feedstock which could introduce contaminants into the environment during biochar application. For instance, in a recent study (Wang et al., 2020), the authors introduced new pyrolysis methods (e.g. microwave-assisted pyrolysis and steam-assisted pyrolysis) and new modified pyrolysis methods (e.g. magnetic modification and mineral modification). Biochars prepared by microwave-assisted pyrolysis can achieve higher degree of carbonisation, improved physicochemical properties (Mašek et al., 2013) and decrease oxygencontaining functional groups (Paunovic et al., 2019). Steam-assisted pyrolysis also generate low oxygen-containing functional groups (Braghiroli et al., 2019). Studies have shown that both microwave- and steam-assisted pyrolysis were effective in removing HMs (Kwak et al., 2019; Mohamed et al., 2017). The decrease of oxygen-containing functional groups may result in both electrostatic interactions and $\pi-\pi$ interactions between aromatic rings of biochar and PAHs (Paunovic 
et al., 2019; Zbair, Ahsaine, \& Anfar, 2018) and effectively immobilising PAHs. The effectiveness of a biochar adsorbent depends on the type of biomass feedstock material and physicochemical properties of individual biochar, such as yield, ash, specific surface area, pore structure, type and number of functional groups and cation exchange capacity (Pandey et al., 2020; Xie et al., 2015). The physicochemical properties of biochar are influenced by several pyrolysis operating parameters, such as type of feedstock material, pyrolysis temperature, heating rate, residence time, and reaction atmosphere.

Generally, any form of organic material can be pyrolyzed to prepare biochar (Laird et al., 2009). However, due to increasing understanding of upcycling and the circular bioeconomy concept in recent years, more attention has been diverted towards utilisation of agricultural organic wastes, particularly agricultural food wastes. Table 3 below shows some common agricultural biomass wastes which have been used to produce biochar and their remediation effects on HMs and PAHs. Figure 2 below shows various agricultural biomass wastes which have been used to prepare biochars with multiple applications. Lignocellulose (cellulose, hemicellulose and lignin), which is an important structural component of biomass cell walls, plays a crucial role in the thermal stability and adsorptive properties of biochar (Jahirul et al., 2012), as well as influencing biochars' physicochemical properties that can, in turn, affect its adsorption efficiency. Hence, a variation in composition and proportion of lignocellulose in individual biomass material results in variations in physicochemical properties of biochars and stability (William and Besler, 1993; Crombie et al., 2013; Leng and Huang, 2018). The feedstock type also affects the carbon content of the biochar, carbon sequestration capacity, and ash content (Zhao et al., 2013). The reaction temperature is another important parameter which influences the physicochemical properties of biochar. Increasing the pyrolysis temperature increases the ash content, specific surface area, pore diameter and $\mathrm{pH}$, while the biochar yield and acidic or oxygencontaining functional groups (e.g. - $\mathrm{COH},-\mathrm{COOH}$ and $-\mathrm{OH}$ ) are reduced (Yang et al., 2019; Tomczyk et al., 2020) as a result of both depolymerisation and dehydration processes (Keiluweit et al., 2010). A decrease in acidic functional groups results in the reduction of negative charges. Low pyrolysis 
temperatures, however, can maintain the structure of the biomass materials whilst undergoing dehydration (Liu and Han 2015).

The pyrolysis process can be divided into slow pyrolysis (SP) and fast pyrolysis (FP) depending on the heating rate (Figure 2). SP involves slow heating rate (minutes to hours, i.e. $<10^{\circ} \mathrm{C} / \mathrm{min}$ ) of biochar material at high temperature $\left(400-600{ }^{\circ} \mathrm{C}\right)$ with a long solid and gas residence time (e.g. 1 hour) in the absence of oxygen (Varma et al., 2019; Bruun et al., 2012; Mohan et al., 2006). SP produces high biochar yield $>30 \%$, which is time and energy efficient (Cong et al., 2018; Tomczyk et al., 2020). Conversely, FP occurs in a high-temperature range of $300-700{ }^{\circ} \mathrm{C}$ at a faster heating rate (milliseconds to seconds, $\left.>10^{\circ} \mathrm{C} / \mathrm{s}\right)$, with a short solid resistance time $(0.5-10 \mathrm{~s})$ and fine particle size ( $<1 \mathrm{~mm}$ ) feedstock (Yang et al., 2019). In FP, solid biomass material decomposes into other forms, such as vapour, aerosol and char. Usually, the biochar yield is $<20 \%$, while the bio-oil yield is $>50$ $\%$ (Wang et al., 2020). As such, FP is recommended when the output is desired in liquid or gas forms (Laird et al., 2009; Tendero et al., 2006). 


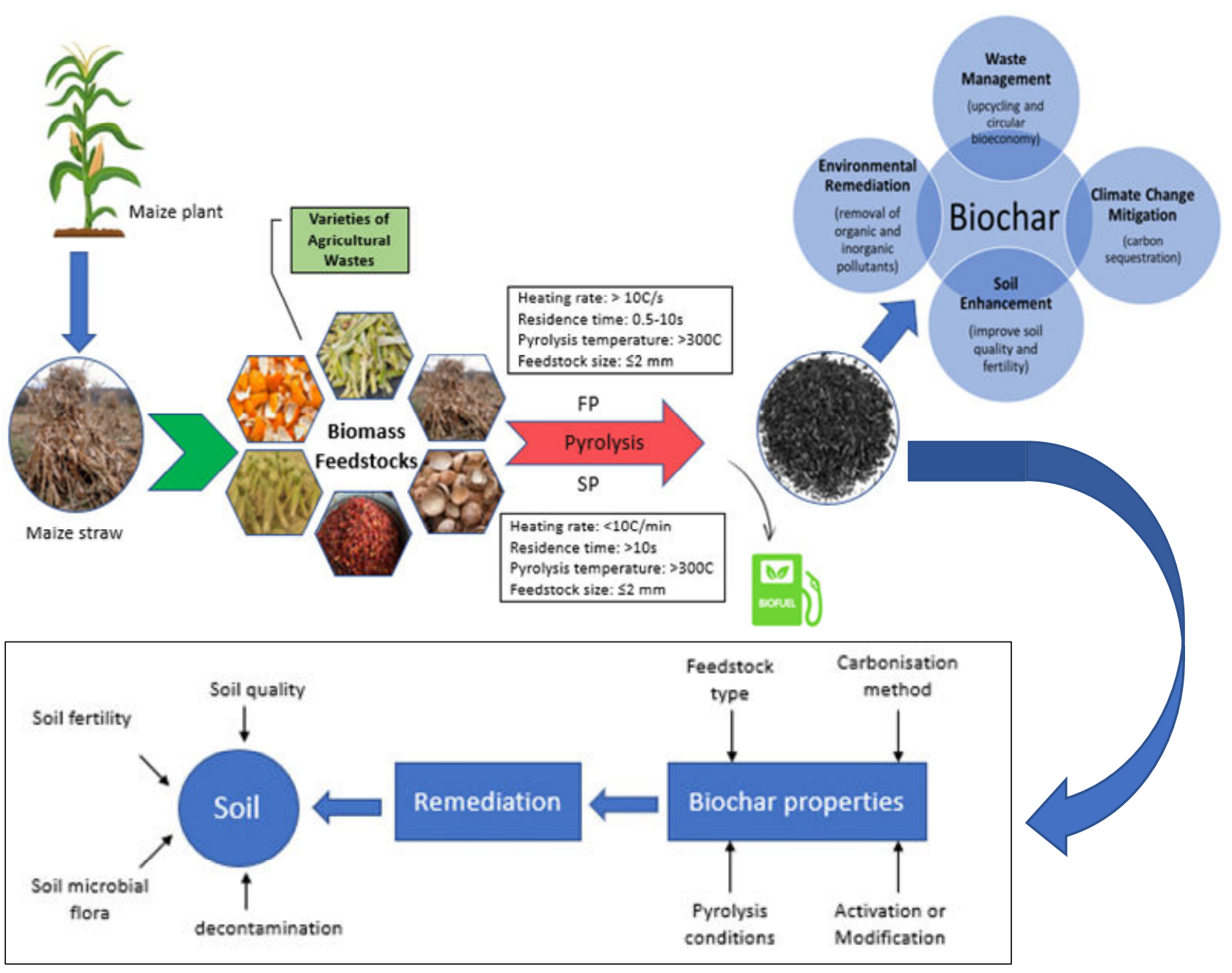

Figure 2. Preparation and application of biochar reusing agricultural waste biomass

The residence time mainly influences physical properties, particularly biochar yield. At a constant temperature, increasing the residence time decreases the biochar yield and enhances biochar carbonisation (Yang et al., 2019; Zornoma et al., 2016; Wang et al., 2020). Residence time can also affect the specific surface area and pore diameter of biochars (Bruun et al., 2012; Chen et al., 2011). Although the beneficial qualities of biochar are well documented by a plethora of studies in the literature, there are some limitations (Table 2). For instance, the ageing of biochar, or its residence time, in the soil is a growing concern. Ageing harms biochar's adsorption efficiency and growth of soil microorganisms. Therefore, the intermittent addition of fresh biochar is required for optimal nutrient cycling (Anyauwu et al., 2018). Several studies have reported weed problem associated with biochar application. For instance, Safaei et al., 2018 reported that biochar can lower herbicide efficacy, resulting in higher consumption of herbicides by weeds. In the same study, the addition of 
7 t/ha bamboo biochar increased the weed biomass 1 and 2 years after biochar amendment approximately $65 \%$ and $80 \%$, respectively. Theoretically, biochar is not a biodegradable substrate but the possibility of biochar undergoing deterioration as a result of aging, chemical oxidation and microbial processes due to potent labile carbon source in itself is a concern (Smith et al., 2010; Cross and Sohi, 2011). Moreover, most of the studies conducted so far originate from short-term experiments in laboratory conditions. Insights in the field application and the long-term effects of biochar remain lacking (Hardy et al., 2019; Maestrini et al., 2014; Sagrilo et al., 2015). 
Table 2. Advantages and disadvantages of selected (bio)engineered remediation technologies of HMS and PAHs

\begin{tabular}{|c|c|c|c|c|}
\hline $\begin{array}{l}\text { (Bio)engineere } \\
\text { d Remediation }\end{array}$ & Advantages & Disadvantages & Efficiency & Ref \\
\hline \multirow[t]{2}{*}{$\begin{array}{c}\text { Biochar } \\
\text { amendment }\end{array}$} & \multirow{2}{*}{$\begin{array}{l}\text { - Immobilise pollutants } \\
\text { - Low cost \& sustainable } \\
\text { - Environmentally friendly } \\
\text { - Sustainable } \\
\text { - Sequestration of carbon } \\
\text { - Improve soil fertility and quality } \\
\text { - Promotes/Involves upcycling } \\
\text { - Promote microbial activity } \\
\text { - Retention of water }\end{array}$} & \multirow{2}{*}{$\begin{array}{l}\text { - Reduce herbicide efficacy \& promote weed } \\
\text { growth } \\
\text { - Could introduce HMs \& PAHs into the soil } \\
\text { - Possible biochar degradation by natural } \\
\text { weathering } \\
\text { - May form colloids affecting microbial activities } \\
\text { - Can have an inhibitory effect on soil ageing thus } \\
\text { requires intermediate biochar addition } \\
\text { - Ageing biochar can affect soil microorganisms }\end{array}$} & \multirow[t]{2}{*}{$\begin{array}{l}\text { Biochar reduced bioavailability of } \mathrm{Cd} \text { and } \mathrm{Pb} \\
\text { in contaminated soil by } 85 \% \text { and } 29 \% \text {, } \\
\text { respectively a and decreased bioavailable } \\
\text { TPH concentration by } 24-28 \%^{\mathrm{b}}\end{array}$} & $\begin{array}{l}\text { Beesley et al., 2011; Manyà, } \\
\text { 2012; Zhang et al., 2012; } \\
\text { Anyanwu et al., 2018; Wang } \\
\text { et al., } 2018\end{array}$ \\
\hline & & & & $\begin{array}{l}\text { aAlaboudi et al., 2019; } \\
\text { 'Cipullo et al., } 2019\end{array}$ \\
\hline $\begin{array}{c}\text { Hydrogel } \\
\text { amendment }\end{array}$ & $\begin{array}{l}\text { - Immobilise pollutants } \\
\text { - Low cost \& sustainable } \\
\text { - Environmentally friendly } \\
\text { - High water retention } \\
\text { - Physiochemically \& thermally stable } \\
\text { - Good mechanical strength } \\
\text { - Good reusability \& biocompatibility } \\
\text { - Wide modifiability } \\
\text { - Moderate degradability }\end{array}$ & $\begin{array}{l}\text { - Difficulty recovering nano/micro-sized hydrogel } \\
\text { - Selective removal and recovery of a targeted } \\
\text { pollutant (e.g. HMs) is a challenge } \\
\text { - The weak force of interaction could lead to } \\
\text { reversible reactions \& disintegration of hydrogel }\end{array}$ & $\begin{array}{l}\text { Hydrogel removed } \mathrm{Pb}^{2+} \text { and } \mathrm{Zn}^{2+} \text { from } \\
\text { aqueous solutions with adsorption capacities } \\
\text { of } 146 \mathrm{mg} / \mathrm{g} \text { and } 287 \mathrm{mg} / \mathrm{g} \text {, respectivelyc. } \\
\text { Another study showed a high removal } \\
\text { efficiency of both monocyclic and PAHs with } \\
\text { a removal efficiency }>60 \% \text { d }\end{array}$ & $\begin{array}{l}\text { Yan et al., 2011; Shalla et al., } \\
\text { 2019; Shen et al., 2011; Tang } \\
\text { et al., 2014; B Wu et al., 2017; } \\
\text { Tang et al., 2010; Tang et al., } \\
2012 \text {; 'Astrini et al., } 2015 \\
\text { 'Filho et al., } 2020\end{array}$ \\
\hline $\begin{array}{c}\text { Digestate } \\
\text { amendment }\end{array}$ & $\begin{array}{l}\text { - Immobilise pollutants } \\
\text { - Low cost \& sustainable } \\
\text { - Environmentally friendly } \\
\text { - Introduce various microorganisms } \\
\text { - Improve soil fertility \& quality } \\
\text { - Low solubility \& biodegradability } \\
\text { - Promotes/Involves upcycling } \\
\text { - Remove pathogens } \\
\text { - Increase microbial diversity } \\
\text { - Increase microbial activities } \\
\end{array}$ & $\begin{array}{l}\text { - Could introduce organic and/or inorganic } \\
\text { pollutants } \\
\text { - Could introduce biological pollutants } \\
\text { - Introduce indigested materials like } \\
\text { stone/plastic/glass } \\
\text { - Long-distance transportation can be costly } \\
\text { - Can lead to nutrient leaching, increase soil } \\
\text { salinity \& } \mathrm{NH}_{3} \text { emission }\end{array}$ & $\begin{array}{l}\text { Digestate improved soil fertility and } \\
\text { microbial activities (increased number of } 16 \mathrm{~S} \\
\text { rRNA genes and dehydrogenase activities) }{ }^{\mathrm{e}} \text {. } \\
\text { A study revealed the reduction of alkane and } \\
\text { TPH by } 99 \% \text { and } 38-57 \% \text {, respectively. }{ }^{\mathrm{f}}\end{array}$ & $\begin{array}{l}\text { Montes et al., 2013; Möller \& } \\
\text { Müller, 2012; Aspray et al., } \\
\text { 2017; Tella et al., 2016; Van } \\
\text { Wezel et al., 2016; Insam et } \\
\text { al., } 2015 \\
{ }^{\mathrm{e}} \text { Garcia et al., } 2015^{\mathrm{f}} \text { Gielnik et } \\
\text { al., 2020a,b }\end{array}$ \\
\hline $\begin{array}{l}\text { Bioaugmented } \\
\text { amendment }\end{array}$ & $\begin{array}{l}\text { - Immobilise pollutants } \\
\text { - Low cost \& sustainable } \\
\text { - Environmentally friendly } \\
\text { - Increase genetic diversity } \\
\text { - Requires little equipment/technology } \\
\text { - Applicable to in-situ and ex-situ }\end{array}$ & $\begin{array}{l}\text { - Competition between exogenous and indigenous } \\
\text { microorganisms } \\
\text { - Predation of exogeneous microorganisms by } \\
\text { protozoa and bacteriophages } \\
\text { - Difficulty delivering inoculant to sub-surface soil } \\
\text { - Selection of suitable microorganisms or their } \\
\text { consortia is a challenge } \\
\text { - Process sensitive to toxicity and physicochemical } \\
\text { condition of the soil }\end{array}$ & $\begin{array}{l}\text { Streptomyces flavomacrosporus significantly } \\
\text { decreased } \mathrm{Hg} \text { from contaminated media }{ }^{\mathrm{g}} \text {. } \\
\text { Gram-positive bacteria showed a significant } \\
\text { reduction }(99 \%) \text { in PAHs concentration }\end{array}$ & 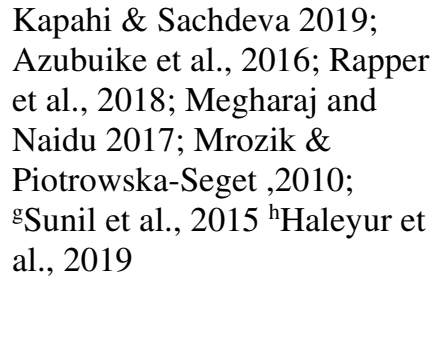 \\
\hline
\end{tabular}




\subsection{Engineered Modification of Biochar for Tailored and Enhanced Remediation Approaches}

One way to reduce the mobility and bioavailability of HMs and PAHs is to increase the binding sites (lessens competitive adsorption) and to introduce HM/PAH tolerant microorganisms capable of removing HMs and degrading PAHs. Biochars can be modified with other materials to produce engineered biochars with increased binding sites and microbial activities. Engineered biochar is the derivative of pristine biochar that is modified to improve its physical, chemical and biological properties (e.g., specific surface area, porosity, cation exchange capacity, surface functional group, pH etc.) and adsorption capacity compared to pristine biochar (Mohamed, Ellis, Kim, Bi, and Emam, 2016; Rajapaksha et al. 2016). The four common engineered methods in which biochars can be modified are physical modification, chemical modification, biological modification and other modification treatments such as UV and magnetic exposures (Peng et al., 2019; Liu et al., 2020; Panahi et al., 2020). Physical modifications mainly affect physical structure of biochar while chemical modification has large effect on biochar's chemical structure including bonds and functional groups (Sajjadi et al., 2019a), and biological modification promote microbial diversity and activities (Gielnik et al., 2019a,b).

\subsubsection{Physical modification}

Physical modification includes traditional gas (e.g. steam, $\mathrm{CO}_{2}$ or ozone), thermal, ultrasound, plasma, and electrochemical modification. Physical modification greatly affects the physicochemical properties of biochar such as surface area, pore volume ash content, $\mathrm{pH}$, aromaticity (H/C), and polarity $(\mathrm{O}+\mathrm{N}) / \mathrm{C}$ (Sajjadi et al., 2019b).

\subsubsection{Biological modification (bioengineered biochar)}

Biological modification of biochar is done to produce bioengineered biochar (Wang et al., 2017). Bioengineered biochar can be produced by amalgamating biochar with biologically pre-treated biomass feedstocks (digestate) through anaerobic digestion (Inyang et al., 2010; Gielnik et al., 2020a,b), or inoculation of contaminant degrading microorganisms onto the surface of biochar (Tu et al., 2020) for enhanced remediation performance. 


\subsubsection{Chemical modification}

Chemical modification, in which char is doped with a chemical agent, is the most common method to modify surface functional groups, though its mechanism is not well understood (Sjjadi et al., 2019a). Chemical modification can be further categorised into oxidation, amination, sulfonation, and impregnation of nanomaterial (metal oxides) into biochar structure (Sajjadi et al., 2019a; Yin et al., 2018). The processes of surface oxidation can be sub-divided into two categories, which uses oxidants (e.g. $\mathrm{HCl}, \mathrm{HNO}_{3}$ or $\mathrm{H}_{2} \mathrm{O}_{2}$ ) and reductants (e.g. $\mathrm{NaOH}, \mathrm{KOH}$ or $\mathrm{NH}_{4} \mathrm{OH}$ ) to increases the hydrophilic properties of the biochar (Liu et al., 2012). Surface oxidation is purposely done to create oxygencontaining functional groups on the surface of biochar. Carboxyl, phenolic hydroxyl, lactones, and peroxides are the most common oxygen containing functional groups formed on biochar after oxidation. Among these groups, hydroxyl and carboxyl groups remarkably improve the adsorption capacity when biochar is utilised for HM removal (Sajjadi et al., 2019a). The use of amino group (e.g. $\left.\mathrm{NH}_{3}\right)$ and/or sulfonic $\left(-\mathrm{SO}_{3} \mathrm{H}\right)$ groups is the most commonly used method for the surface amination and sulfonation of biochar for acidic materials (Sajjadi, et al., 2019a). The metal impregnation, which uses heteroatoms (e.g. $\mathrm{Mg}, \mathrm{Mn}, \mathrm{Ca}, \mathrm{Cu}, \mathrm{Ni}$, and $\mathrm{Fe}$ ) oxides to increase the specific surface area of the biochar and, thus, improving its general adsorptive properties (Yin et al., 2018; Li et al., 2016; H. Wu et al., 2017). However, the cost associated with the number and volume of chemicals can be costly and there is a greater risk of these chemicals becoming released into the environment, thus generating secondary pollution.

\subsection{Hydrogel Assisted Remediation}

\subsubsection{Application and properties}

A hydrogel is a three-dimensional network of hydrophilic polymers which are crossed-linked and flexible, and that can swell in water or biological fluid and retain a large volume of water while maintaining its structure (Chai et al., 2017; Ahmed, 2015). Apart from its widespread applications in bioengineering, biomedicine, agriculture, sensors, food industry and water purification and separation 
processes (Annabi et al., 2014; Zhou et al., 2017; Liu and Li 2017; Xu et al., 2017), hydrogels have been recently used as a sorbent for the removal of metal ions from water and aqueous media (Rehman et al., 2019; Pathan and Bose, 2018, Du et al., 2020). The application of hydrogels in metal removal is attributed to its hydrophilic properties, largely conferred by hydrophilic functional groups, such as hydroxyl, carboxyl, sulfonic acid and amide (Rehman 2019; Askari et al., 1993).

\subsubsection{Adsorption process and mechanism}

Generally, the adsorption process of hydrogels can be divided into two sub-systems called chemical sorption and physical sorption. Chemical sorption is an irreversible system characterised by the formation of a chemical bond between the adsorbate (e.g. HMs) and the adsorbent (the hydrogel), while physical sorption is a reversible system characterised by weak physical interactions between the adsorbate and adsorbent - these include electrostatic interactions, hydrogen bonding, van der Waals bonds, co-ordination bonds and hydrophobic interactions (Holback et al., 2011; Buenger et al., 2012; Abeer et al., 2014; Liu et al., 2014; Pourbeyram and Mohammadi, 2014).

\subsubsection{Synthesis: method and key ingredients}

Hydrogels are synthesised by various methods, such as by freeze-drying, pyrogenation, microemulsion formation and segment separation (Butylina et al.,2016; Badiger et al., 1993; Ghayempour and Montazer, 2018; Omidian et al., 2005). However, free radical polymerisation (FRP) is regarded as the most widely used method to prepare hydrogels and also other polymers with successive addition of free-radical building blocks (Shinde et al., 2013; Thakur and Thakur, 2014). FRP is widely used because it acts as a synthesis route for obtaining a wide variety of different polymers and material composites. Also, the relatively non-specific nature of free-radical chemical interactions makes FRP one of the most versatile of methods for manufacturing polymers (Tesinova, 2011; Kim and Sikes, 2020; Gao et al., 2020). In general, a typical hydrogel synthesis requires a backbone polymer (e.g. sodium alginate), monomer (e.g. acrylic acid), crosslinker (N-N' methylene bis-acrylamide) and an initiator (e.g. potassium persulfate) (Verma et al., 2020). The formation of a gel is a result of weak and strong interactions tethering the properties of the hydrogel construct (Ajdary et al., 2020). Other researchers have argued that the use of synthetic chemical backbone polymers could lead to secondary pollution, and as such have recommended the use of biopolymers (biosorbents), such as cellulose and lignin, which are more eco-friendly and foster the circular bioeconomy concept (Coviello et al., 2007; Klein and Poverenov, 2020; Kabir et al., 2018; Ajdary et al., 2020). Recent advances have explored the use of natural biopolymers, such as polysaccharides, proteins and lipids among others. For instance, several hydrogels have been used as biosorbents, for 
example cellulose graft acrylic acid (C-g-AA), chitosan hydrogel, PVA-hydrogel biomass of Penicillium cyclopium, and starch graft acrylic acid/montmorillonite (S-g-AA/MMT) (Jamnongkan et al., 2014). However, the application of biosorbent polymers to treat contaminated soils can result in their degradation by soil microorganisms, thus shortening their remediation life span without achieving their expected function (Nair et al., 2017). On the other hand, synthetic polymers are less susceptible to natural and biological degradation, often making them an ideal choice for contaminated soil remediation (Leja and Lewandowicz, 2010).

\subsubsection{Factors affecting the adsorption capacity}

The swelling and sorptive behaviour of a hydrogel is largely influenced by factors such as $\mathrm{pH}$ of contaminated media (Cao et al., 2011), ionic energy, the composition of adsorbate and adsorbent, contact time, initial concentration, temperature, light chemical species, electric and magnetic fields (Chen et al., 2013; Bekin et al., 2014; Chatterjee et al., 2010). However, pH has been reported to have a significant influence, particularly in having selective adsorption for metal species compared to other factors. Studies have shown that maximum adsorption efficiency can be achieved at a $\mathrm{pH}$ range between 4 and 6 (Hua et al., 2012; Dragan, 2014).

\subsubsection{Hydrogel-assisted remediation studies}

Hence, by amalgamating biochar with hydrogel (i.e. biochar-hydrogel composite) would enhance the adsorption efficiency of biochar. Enhanced remediation could lead to the less intermittent application of ageing biochars or quicker remediation output time compared to biochar when applied alone. Also, the mechanical stability of hydrogels could provide stability to biochar when subjected to natural degradation, thus improving its life span. Moreover, the reusability (sustainably economical), lowcost associated with the purchase of chemicals needed for hydrogel synthesis, and biocompatibility (harmless to the physiology of biological organisms) of hydrogels add to the advantage of hydrogel (Table 2). The most common monomer for polymerizing hydrogel is acrylamide, whose market price can be as low as $\$ 1 / \mathrm{kg}$ ( $\mathrm{Li}$ and Chen, 2018). Several studies of biochar-hydrogel composite applications investigated for remediation of PAHs and HMs have yield positive results. M. Zhang et al. (2020) and W. Zhang et al. (2020) used waste biomass based hydrogel soybean residuepoly(acrylic acid) (SR-PAA) to remove $\mathrm{Cd}^{2+}$ and $\mathrm{Pb}^{2+}$ ions from aqueous solutions. It was found that 
the adsorption equilibrium was achieved within 20 min, and maximum adsorption for $\mathrm{Cd}^{2+}$ and $\mathrm{Pb}^{2+}$ ions were 1.43 and $2.04 \mathrm{mmol} \mathrm{g}^{-1}$, respectively. The adsorption of metal ions was not much affected during the subsequent adsorption-desorption cycles. After 5 cycles of regeneration and reuse, the adsorption for $\mathrm{Cd}^{2+}$ and $\mathrm{Pb}^{2+}$ ions were 1.01 and $1.50 \mathrm{mmol} \mathrm{g}{ }^{-1}$ which corresponded to $70.6 \%$ and $73.9 \%$ of adsorption capacity of the first cycle, respectively. Li and Chen (2018) investigated the adsorption behaviour of wood waste biochar-hydrogel composite to remove $\mathrm{Cd}^{2+}$ from aqueous media. The composite achieved a swelling capacity of 1,506\% compared to the hydrogel (818\%) when used alone. The maximum adsorption capacity of the composite was reported $63.58 \mathrm{mg} \mathrm{g}^{-1}$ compared to untreated hydrogel $\left(24.72 \mathrm{mg} \mathrm{g}^{-1}\right)$. The increased maximum adsorption capacities of the hydrogel composite to remove $\mathrm{Cd}^{2+}$ was attributed to synergistic effect of polyacrylamide hydrogelbiochar composite. The reason for the synergistic effect was linked to each single biochar particle scattered in the composite creating an ionic attraction field for attracting and retaining metallic ions such as $\mathrm{Cd}^{2+}$. This ionic attraction field significantly extended the potential of each biochar particle to entrap ions within the cross-linked composite structure against large concentration gradient of ions (Li and Chen, 2018). The formation of many ionic attraction fields around the scattered biochar particles made it possible to overcome the ionic osmotic stress, the main factor regulating the sorption and release of ions in hydrogel materials (Wang et al., 2014). Another study used a novel three dimensional $\mathrm{MnO}_{2}$ modified biochar-based porous hydrogel (MBCG) composite to eliminate $\mathrm{Cd}^{2+}$ and $\mathrm{Pb}^{2+}$ ions. The maximum MBCG adsorption capacity on $\mathrm{Cd}^{2+}$ and $\mathrm{Pb}^{2+}$ was 85 and $71 \mathrm{mg} \mathrm{g}^{-1}$, respectively. Just like SR-PPA, MBCG was separated and regenerated with an excellent reusability, which retained $92.1 \%$ and $80.5 \%$ of the initial adsorption capacities of $\mathrm{Cd}^{2+}$ and $\mathrm{Pb}^{2+}$ after 5 cycles (Wu et al., 2020). A hydrogel-biochar (rice husk) composite (HBC-RH) was utilised for the removal of zinc from wastewater. The maximum monolayer sorption capacity of $\mathrm{HBC}-\mathrm{RH}$ for $\mathrm{Zn}^{2+}$ was 35.75 $\mathrm{mg} \mathrm{g}^{-1}$ (Sanyang et al., 2014). The nanosorbent (N-PSPB/SHGL) was fabricated based on encapsulation of derived nanoscale spherical biochar from Pisum sativum pods (N-PSPB) with starch hydrogel (SHGL). N-PSPB/SHGL attained a high swelling capacity of $500 \%$ with excellent stability 
for ten cycles with respect to regeneration by $0.1 \mathrm{~mol} \mathrm{~L}^{-1} \mathrm{HCl}$ (Mohamed and Mahmoud, 2020). Biochar/pectin/alginate hydrogel beads (BPA) derived from grapefruit peel were synthesised and used for $\mathrm{Cu}^{2+}$ removal from aqueous solution. The adsorption capacity of $\mathrm{Cu}^{2+}$ onto optimised BPA9 reached maximum values of $36.25 \pm 0.33 \mathrm{mg} \mathrm{g}^{-1}$ at $\mathrm{pH} 6$ (Zhang et al., 2020). 
Table 3. Remediation of contaminated soil by biochars derived from various agricultural biomass wastes

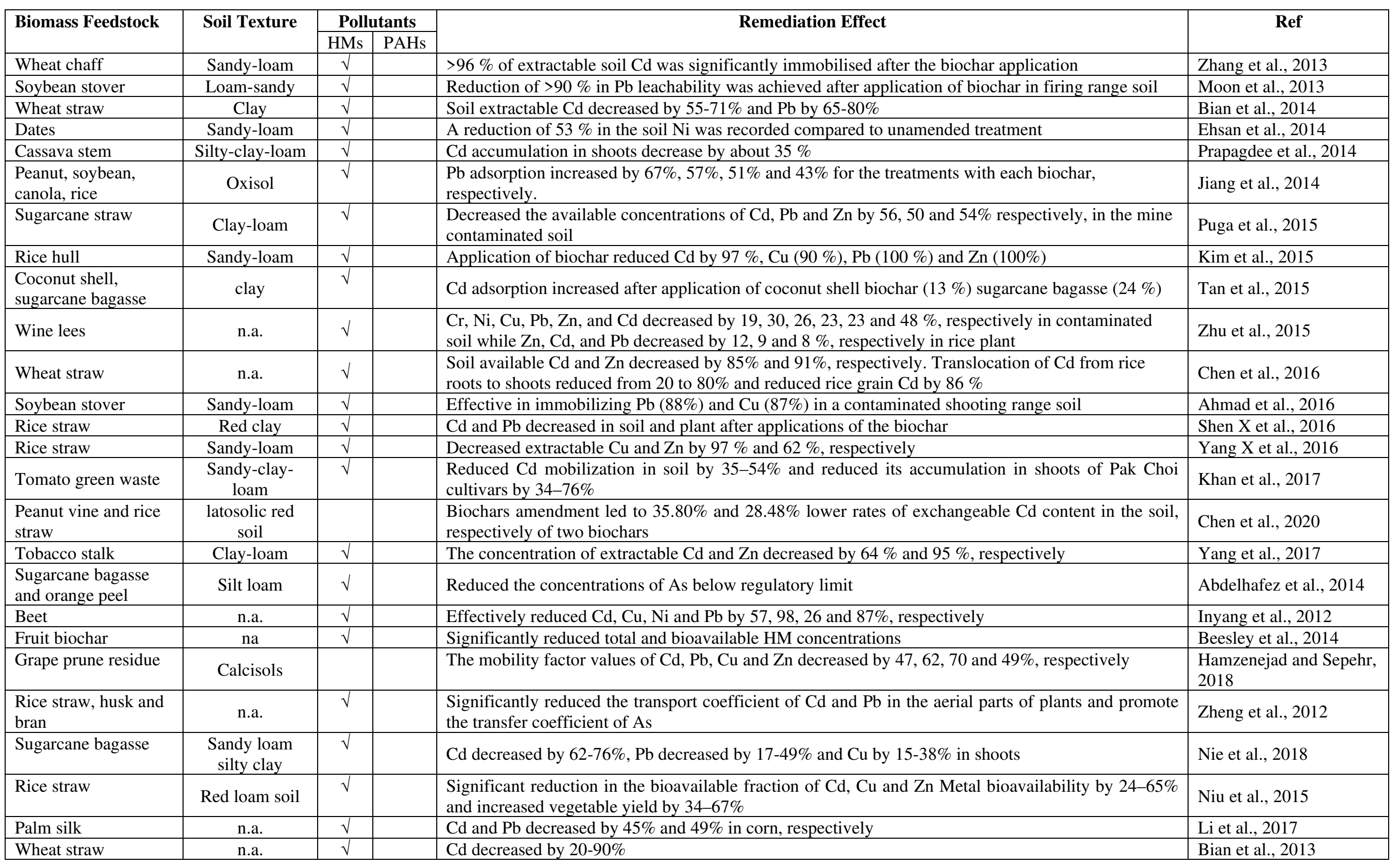




\begin{tabular}{|c|c|c|c|c|c|}
\hline Rice husk & n.a. & $\sqrt{ }$ & & Cd decrease by $69 \%$ & Guo et al., 2016 \\
\hline Rice straw & ultisol & & & Decreased $\mathrm{Cu}$ and $\mathrm{Pb}$ by $20-100 \%$ and $19-77 \%$, respectively & Jiang et al., 2012 \\
\hline $\begin{array}{l}\text { Beanstalk and rice } \\
\text { straw }\end{array}$ & n.a. & $\sqrt{ }$ & & $\mathrm{Cd}, \mathrm{Zn}$ and As decreased by $21-67 \%$ & Meng et al., 2018 \\
\hline Agriculture residues & Loamy sand & $\sqrt{ }$ & & Achieved reduction of expendable $\mathrm{Pb}$ and $\mathrm{Cd}$ by $28.68 \%$ and $85.14 \%$, respectively & Alaboudi et al., 2019 \\
\hline Pecan shell & na & $\sqrt{ }$ & & Adsorbed $61 \%$ more $\mathrm{Pb}$ & Crisler et al., 2019 \\
\hline Vegetable wastes & sandy loam & $\sqrt{ }$ & & Achieved $\mathrm{Pb}$ immobilization of $87 \%$ & Igalavithana et al., 2019 \\
\hline Miscanthus straw & Sandy loam & $\sqrt{ }$ & & Reduction of bioavailable fraction reached $92 \%, 87 \%$ and $71 \%$ for $\mathrm{Cd}, \mathrm{Zn}^{2+}$ and $\mathrm{Pb}^{2+}$, respectively & Houben et al., 2013 \\
\hline Rice straw & Sandy loam & $\sqrt{ }$ & & Reduced $\mathrm{Pb}^{2+}$ and $\mathrm{Cu}^{2+}$ by $71 \%$ and $46 \%$, respectively in Sedum plumbizincicola & Lu et al., 2014 \\
\hline Maize stover & n.a. & & $\sqrt{ }$ & $\begin{array}{l}\text { Decreased PAHs by } \leq 57 \% \text {. Studied PAHs include: naphthalene, phenanthrene, anthracene, } \\
\text { fluoranthene, pyrene, benzo(a)anthracene, chrysene, benzo(b) fluoranthene, benzo(k) fluoranthene, } \\
\text { benzo(a) pyrene, indeno( } 1,2,3 \mathrm{~cd}) \text { pyrene, } \operatorname{Benzo}(\mathrm{g}, \mathrm{h}, \mathrm{i}) \text { perylene }\end{array}$ & Oleszczuk et al., 2012 \\
\hline Soybean stalk & n.a. & & $\sqrt{ }$ & Removed naphthalene by $100 \%$, phenanthrene by $100 \%$ and acenaphthene by $96 \%$ & Kong et al., 2011 \\
\hline Wheat straw & n.a. & & $\sqrt{ }$ & Phenanthrene, fluoranthene, pyrene achieved 96-99\% removal efficiency & Li et al., 2014 \\
\hline Sugarcane bagasse & n.a. & & $\sqrt{ }$ & Increased removal of PAHs contained in highly polluted soil by up to $40 \%$ & Trejo-Hernandez. 2007 \\
\hline $\begin{array}{l}\text { Plant residues and } \\
\text { empty fruit bunches }\end{array}$ & Sandy-loam & & $\sqrt{ }$ & $\begin{array}{l}\text { PAHs accumulation was reduced concerning time for organic waste/plant residues. Thus, it enhanced } \\
\text { soil modification on application }\end{array}$ & Zeng et al., 2018; \\
\hline Olive pomace & n.a. & & $\sqrt{ }$ & Pyrene concentration was reduced by $70 \%$ after 28 days of biochar application & Piscitelli et al., 2019 \\
\hline Rice straw & Sandy soil & & $\sqrt{ }$ & Addition of biochar achieved highest biodegradation rate of PAHs by $40-59 \%$ & Zhang et al., 2020 \\
\hline Peanut shell & & & $\sqrt{ }$ & Bioaccumulation reduction of PAHs by $71-84 \%$ & Khan et al., 2015 \\
\hline $\begin{array}{l}\text { Walnut shell, corn } \\
\text { straw \& rice straw }\end{array}$ & Sandy loam & & $\sqrt{ }$ & increased biodegradation rate of chrysene by $3-45 \%$ & Zhang et al., 2018 \\
\hline Corn straw & $\begin{array}{l}\text { Sandy loam } \\
\text { silty clay }\end{array}$ & & $\sqrt{ }$ & Reduced bioavailable $2(+3)-, 4-$, and 5-ring PAHs in rice roots by $10 \%, 40 \%$ and $40 \%$, respectively & Ni et al., 2018 \\
\hline Maize straw & $\begin{array}{l}\text { Sandy loam } \\
\text { silty clay }\end{array}$ & & $\sqrt{ }$ & Decreased PAH from contaminated soil by $30 \%$ & Li et al., 2019a,b \\
\hline Wheat straw & n.a. & & $\sqrt{ }$ & Degradation of $\Sigma$ PAHs in contaminated soil increased by $38 \%$ & Cao et al., 2016 \\
\hline Rice hull & n.a & & $\sqrt{ }$ & Increased removal efficiencies of all two-ring to four-ring PAHs by 35 to $37 \%$ & Liu et al., 2015 \\
\hline
\end{tabular}

n.a. not available 


\subsection{Digestate Amendment}

\subsubsection{Source and classification}

From the many years of bioremediation studies and research, little remains unknown about the contribution of microorganisms from digestate to the overall efficiency of contaminant removal and the role of digestate as biostimulant in the remediation of HMs and PAHs. Digestate as a biostimulant is mainly attributed to the rich nutrient content of digestate contributing to increase microbial population and activities, in return, the microorganisms remove the pollutants (Gielnik et al., 2019a,b). Digestate is produced by anaerobic digestion (AD) of organic fraction of municipal solid wastes (OFMSW) and agricultural food wastes (AFW). Digestate is composed of three parts: undigested feedstock, microbial organisms, and microbial metabolites. The solid part of digestate after mechanical solid-liquid separation or natural sedimentation is called solid digestate, while the liquid part is called liquid digestate (Deng et al., 2020). Like biochar, the application of digestate employs and promotes the concept of upcycling and circular bioeconomy by utilising OFMSW and AFW to enhance pollution remediation, with environmental, agricultural and economic benefits (Logan and Visvanathan, 2019). Unlike AFW, which entirely consists of organic wastes, MSW consists of various types of wastes like paper, glass, metal, plastic, textiles and other organic wastes. The composition and proportion (proportional \% of an individual type of waste) of MSW varies across the world. In the developing world, MSW contains a rich organic fraction, while in more developed countries the major fraction of MSW comes from plastic and paper. For example, organic wastes constitute more than $50 \%$ of Thailand's MSW (Thi et al., 2015). Poor management and disposal of OFMSW and AFW in landfills can lead to uncontrolled anaerobic decomposition, thus resulting in soil and water pollution, bad odour, and production of methane and other pollutant gases released to the atmosphere (Sisto et al., 2017; Psomopoulos et al., 2009). For instance, the Food and Agriculture Organization (FAO) of the United Nations estimated that 1.3 billion tons of edible food is wasted globally each year resulting in $250 \mathrm{~km}^{3}$ of corresponding wasted water and an addition of 3.3 billion tons of $\mathrm{CO}_{2}$ emissions to the atmosphere (FAO, 2013). Instead, the OFMSW and AFW 
can be upcycled to produce digestate with rich nutrients (organic fertilizers) that is cheaper compared to inorganic fertilizers. It can act as the carrier of microorganisms capable of removing HMs and degrading PAHs. Moreover, it supports carbon sequestration in soil organic matter (SOM), thereby reducing the emission of greenhouse gasses such as $\mathrm{CO}_{2}$.

\subsubsection{Nutritional properties (bio-fertiliser)}

The nutrient-rich digestate usually contains a dense and diverse microbial population which can degrade PAHs and remove HMs (Mrozik and Piotrowska-Seget, 2010; Agnello et al., 2016). Nutrients from digestate and exogenous microorganisms (respective to indigenous microorganisms in the soil) inhabiting the digestate can promote microbial abundance, diversity and activities (Gielnik et al., 2019a,b; Ogbonna et al., 2018). Recently, the use of digestate as an organic fertilizer has generated interest in soil science due to its high concentration of nutrients that are present in bioavailable form and low level of easily degradable carbon (Tambone et al., 2010; Walsh et al., 2012; Kataki et al., 2017).

\subsubsection{Digestate-assisted remediation with biochar}

A 60-day incubation experiment was set up on a French technosol which was heavily contaminated with $\mathrm{Pb}$ due to former mining activities. After 30 days of incubation, cow manure biochar reduced Cd and Zn by $90 \%$ and $80 \%$, respectively, and digestate by $63 \%$ and 73\%, respectively, compared to the control (Van Poucke et al., 2020). Bianco et al., (2020) showed that contaminated soil amended with digestate after 120 days reduced PAHs by $43 \%$. Several laboratory-scale studies added digestate and organic matter $(\mathrm{OM})$ to contaminated soil have shown significant improvement in the rate of hydrocarbon biodegradation (Namkoong et al., 2002; Juteau et al., 2003; Kriipsalu et al., 2007; Sayara et al., 2010). A 2 months incubation of soil with digestate increased alkB genes (encoding enzymes responsible for the degradation of saturated hydrocarbons) to $11.5 \%$ and after the addition of hydrocarbon degrading bacteria immobilised onto biochar, this value increased up to $60 \%$. The application of digestate positively affected soil respiration and bacterial density, and decreased petroleum hydrocarbons by $74 \%$, while extra addition of bacteria immobilised onto biochar increased 
this value up to $95 \%$ (Gielnik et al., 2020a,b). A similar study examined digestate as a potential nutrient and microbial seeding for bioremediation of weathered (aged) petroleum hydrocarbon contaminated (TPH) soils (Gielnik et al., 2019a,b). After 30 days of incubation, the TPH removal was observed in microcosms containing digestate together with a bulking agent (18\% and $13 \%$ higher than control in clay-rich soil and sandy soil, respectively) or digestate together with immobilised bacteria (13\% and 9\% higher than control in clay-rich soil and sandy soil, respectively). Quantification of alkB genes in the digestate was extremely high application of digestate. The same study revealed the promising potential of digestate as a source of nutrients and bacteria for soil bioremediation. Hence, biochar-digestate composite can be bioengineered to harbour selected microbial consortia that will comprise a biochemical system that will enhance the reclamation of contaminated soil beyond conventional methods. In addition to its advantages, it is deemed costeffective, environmentally friendly, sustainable and requires less effort and equipment (Table 2).

\subsection{Microbe-Assisted Remediation}

\subsubsection{Remediation process and mechanism}

Another bioremediation technique is bioaugmentation which employs adding microorganisms to immobilise HMs and PAHs, including to degrade the latter. Just like hydrogels and digestate, microorganisms (e.g. bacteria, fungi and/or alga) can be seeded with biochar to enhance its remediation efficiency. Microorganisms can release contaminant-degradative enzymes into the environment to break-down organic contaminants such as PAHs. During microbial degradation, PAHs are degraded, which is complete will become mineralised to $\mathrm{CO}_{2}$ and $\mathrm{H}_{2} \mathrm{O}$ (Yakimov et al., 2007). The uptake and storage of HMs by microorganisms can be achieved through either by an active process called bioaccumulation (i.e. absorption of HMs at a faster rate than at which it is lost by catabolism and excretion) or passively via adsorption process (binding of metals ions to anionic functional groups). The cell walls of microorganisms consist of various functional groups such as carboxylate, hydroxyl, amino, sulfate, amine, and phosphate, which provides a negatively charged 
surface that can attract positively charged metal ions from soil (Abdi and Kazemi, 2015 Vijayaraghavan and Yun, 2008). The opposite charges facilitate for one or a combination of various interactions like electrostatic forces, and van der Waals forces (Rajendra et al., 2003). Table 4 summarise various chemical interactions involved in the remediation mechanism of biochar and bioaugmentation. Microorganisms which have the capability of accumulating HMs in their bodies pose an inherent characteristic for converting toxic forms of HMs into non-toxic or less toxic forms through various mechanisms to avoid potential health effects of metal toxicity. The bioaccumulation mechanisms can be grouped into an extrusion system (e.g. removal of metal-mediated by chromosomal or plasmid actions), biotransformation (biological conversion of metals from toxic to non-toxic form), enzyme utilization (e.g. the conversion of toxic metal to the metabolic product by oxidase and reductase), exopolysaccharide (EPS) production (a physiological adaptation of hydrophobic cell membrane via secretion of EPS), and synthesis of metallothioneins which form complexes with metals (Dixit et al., 2015; Garbisu and Alkorta, 2003; Singh and Ward, 2004; Wu et al., 2010). Whilst a metal tolerant microorganism which can undergo all the bioaccumulation mechanisms would be considered an ideal species for the remediation of soil polluted with HMs and/or PAHs, such an organism remains undiscovered or not yet bioengineered. Therefore, microorganisms possessing various mechanisms are combined to form a mixed culture with improved mechanisms and features.

\subsubsection{Bactoremediation, mycoremediation and phycoremediation}

In recent years, bactoremediation (employ bacteria for detoxification) using actinobacteria have received special attention as candidates for bioremediation due to their proven versatility and abundance in the environment. Actinobacteria are a group of Gram-positive bacteria with high guanine and cytosine content in their DNA and constitute the largest bacterial phyla (Barka et al., 2016). For example, Alvarez et al., (2017) reported the ability of actinobacteria in removing HMs and pesticides simultaneously. Generally, Gram-positive bacteria are recognised as most effective in the removal of HMs due to presence of glycoproteins compared to Gram-negative bacteria comprising 
phospholipids and lipopolysaccharides (Das et al., 2008; Gourdon et al., 1990). Chang et al., (2019) had shown that augmenting biochar with Pseudomonas sp. DC-B1 and Bacillus sp. DC-B2 performed well in reducing $\mathrm{Hg}^{2+}$ contents in soil, lettuce shoots and roots, achieving a decrease of 12-27\%, 25$58 \%$ and 2-49\%, respectively. Similarly, Gram-positive bacteria are quite effective PAH degraders and are often found as the dominant group of species over other bacterial species that are present in PAH-contaminated soil (Haleyur et al., 2019). Apart from commonly used bacteria for microbial remediation, the capabilities of fungi and alga to remove HMs and PAHs in contaminated soils had been studied. For example, A mycoremediation (employing fungi for detoxification) study by Lakkireddy and Kues (2017) utilised mushroom Coprinopsis atramentaria to achieve a Cd removal efficiency of $76 \%$ at $1 \mathrm{mg} \mathrm{L}^{-1}$ and $\mathrm{Pb}^{2+}(9 \%)$ at $800 \mathrm{mg} \mathrm{L}^{-1}$. A similar study by Fernandez et al., (2017) used psychrotolerant yeasts reported having removed $80 \%$ of $1 \mathrm{nM}$ of $\mathrm{Cr}^{6+}, 55 \%$ of $\mathrm{Cd}^{2+}$ and $80 \%$ of $\mathrm{Cu}^{2+}$. The ability of algae has also been reported to remediate HMs in several studies. The term 'phycoremediation' is used to denote macro-algal-, micro-algal- or cyanobacterial-mediated remediation, either through the removal (e.g. biosorption) or degradation and assimilation of HMs (Chabukdhara et al., 2017). Like bacteria, the surface of algal cells consists of various functional groups (e.g. - $\mathrm{OH},-\mathrm{COOH}, \mathrm{NH}_{2} \mathrm{CO}$ and $\mathrm{PO}_{4}{ }^{3-}$ ), which form the negatively charged surface that acts as metal-binding sites to attract positively charged toxic metal/metalloid ions (Abbas et al., 2014; He and Chen, 2014). For example, the cell wall of brown macro-algae (Phaeophyta) possess a significant level of carboxyl groups which acts as a sink for HMs via electrostatic attraction, thus behaving as a hyperaccumulator species (Ali et al., 2017; Sharma et al., 2018).

\subsubsection{Microbe-assisted remediation studies}

In a 75 days pot experiment, biochar was used as a carrier for immobilising $\mathrm{Cd}-\mathrm{Cu}$ tolerant strain NT2 (Pseudomonas sp.). The bacteria NT-2 loaded biochar decreased the bioavailability of $\mathrm{Cd}^{2+}$ and $\mathrm{Cu}^{2+}$ from $29.5 \mathrm{mg} \mathrm{kg}^{-1}$ to $20.8 \mathrm{mg} \mathrm{kg}^{-1}$ and from $127.3 \mathrm{mg} \mathrm{kg}^{-1}$ to $73.4 \mathrm{mg} \mathrm{kg}^{-1}$, respectively. The enriched biochar also increased soil enzyme activity and greatly improved soil microbial community profile (Tu et al., 2020). Chen et al., (2019) applied phosphate-solubilising bacteria (PSB) modified 
biochar to enhance immobilisation of $\mathrm{Pb}^{2+}$ by rice biochar $(\mathrm{RB})$ and sludge biochar $(\mathrm{SB})$. The study showed that the $\mathrm{RB}$ and $\mathrm{SB}$ effectively removed $\mathrm{Pb}^{2+}(18.61 \%$ and $53.89 \%$, respectively). But, the higher reduction of $\mathrm{Pb}^{2+}$ was achieved from colonisation of $\mathrm{RB}$ and $\mathrm{SB}$ with $\mathrm{PSB}(24.11 \%$ and 60.85 $\%$, respectively). Similarly, corn straw biochar and pig manure biochar were studied as carriers of a mutant genotype from Bacillus subtilis (B38) for heavy metal contaminated soil remediation. After amendment with bacteria loaded biochars, the heavy metal $(\mathrm{Cd}, \mathrm{Cr}, \mathrm{Hg}$ and $\mathrm{Pb})$ concentrations in the edible part of lettuce decreased by 70 - $96 \%$ (Wang et al., 2017). Ejaz (2016) applied biochar at the rate of $1 \%$ and $2 \%$ in each pot containing $10 \mathrm{~kg}$ heavy metal $(\mathrm{Ni}, \mathrm{Cd}$ and $\mathrm{Pb}$ ) contaminated soil. Three different strains of endophytic bacteria i.e. FD-17, KS-54 and PsJN were applied. The levels of $\mathrm{Ni}, \mathrm{Cd}$ and $\mathrm{Pb}$ decreased up to $40 \%, 59 \%$ and $14 \%$, respectively, over control, by combined application of FD-17 and KS-54 in 2\% biochar amended soil. Another study mixed three strains Bacillus subtilis, Bacillus cereus, and Citrobacter sp. in a 3:3:2 proportion as a kind of mixed bacteria (MB9) consortium to detoxify co-contaminated soil with U and Cd. Two types of MB9-loaded biochar were synthesised namely AIB and EIB. After 75 days, the highest reduction in the extractable $\mathrm{U}(69 \%)$ and Cd (56\%) was achieved with the 3\% AIB amendment (Qi et al., 2020). Another study demonstrated enhanced bioremediation of contaminated soil having a long history of PAH contamination by immobilising bacteria (Pseudomonas putida and an unidentified indigenous bacterium) onto biochars as carriers. The individual removal percentages of phenanthrene and pyrene were $22-38 \%$ and $39-40 \%$ in the treatment amended with free bacteria and increased to $46-47 \%$ and 77-78 \% after amended with immobilised-bacteria, respectively (Chen et al., 2012). Xiong and Co-workers (2017) inoculated rice straw biochar with PAH-degrading Mycobacterium gilvum, and the subsequent amendment of this composite material to PAHs contaminated soil. The microbebiochar composite showed superior degradation capacity for phenanthrene $(62.6 \pm 3.2 \%)$, fluoranthene $(52.1 \pm 2.3 \%)$ and pyrene $(62.1 \pm 0.9 \%)$.

Although bioaugmentation has shown great potential in immobilizing HMs and PAHs, there are limitations associated with its application. For example, it initiates competition between exogenous 
and indigenous microorganisms for nutrient and/or predation of exogenous microorganisms by inhabiting protozoa and bacteriophages. Inoculation of exogenous microorganisms to sub-surface soil could be problematic. It is easy to disperse into surface soil, but it is difficult to do the same in the subsurface soil environment (Mrozik and Piotrowska-Seget, 2010). Also, the selection of a suitable effective strain of microorganisms or their consortia could be a challenge. Successful soil augmentation does not entirely require a sound knowledge on type and level of contaminants but suitable strains of microorganisms and their consortia. Mrozik and Piotrowska-Seget (2010) reported specific features of microorganisms to be considered during the selection of proper cultures. This includes fast-growing, easy cultured, to withstand high concentration of contaminants, and the ability to survive in a wide range of environmental conditions.

\subsection{Remediation Mechanism of Biochar}

In recent years, numerous studies have documented the remediation or sorption mechanisms of biochar (e.g. Wang et al., 2020; Cheng et al., 2020; Oliveira et al., 2017). However, little has been done to understand the remediation mechanism of (bio)engineered biochar and how the integrated material could improve biochar's sorption abilities; thus, contributing to enhancing pollutant removal efficiency. Generally, remediation mechanisms differ based on the type of contaminant and the type of biochar feedstock material. Similarly, the remediation mechanism varies based on the type of hydrogel, digestate and bioaugmentation microorganisms. The dominant remediation mechanisms of biochar involve in the removal of both organic (e.g. PAHs) and inorganic (e.g. HMs) are illustrated in Figure 3 and summarised in Table 4 below. The removal mechanisms are often governed by the interactions of pollutants with various attributes of biochar. 


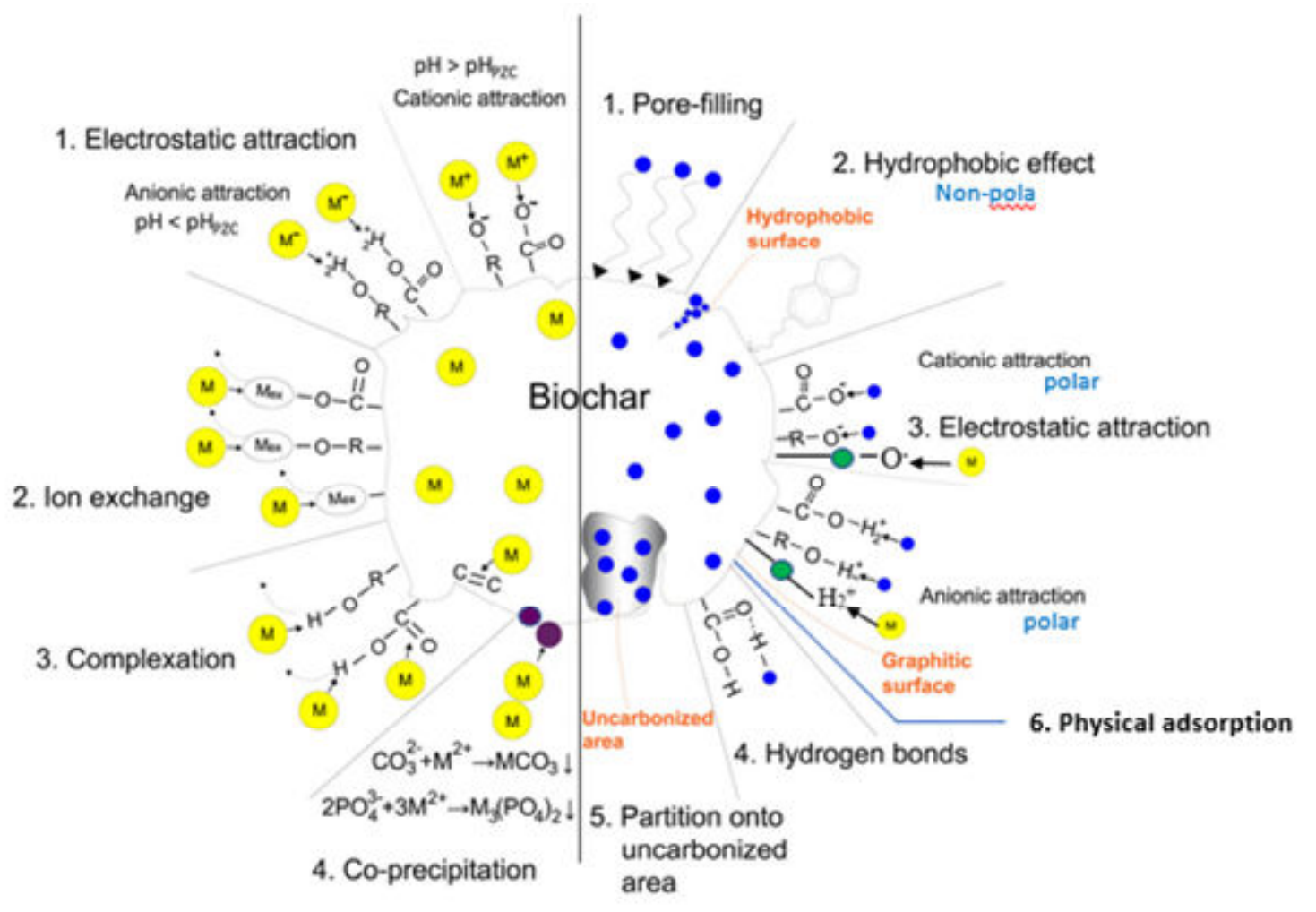

Heavy metals

Organic contaminants

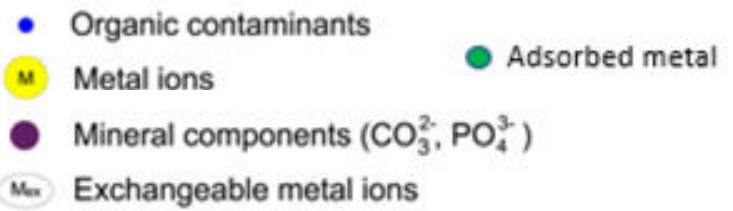

Figure 3. Sorption interactions between biochar and pollutants (Modified from Wang et al., 2020b)

For inorganic pollutants, such as HMs, the remediation mechanisms of biochar very much depend on the valence state of the target metal ion(s) of interest at different $\mathrm{pH}$ (Li et al., 2017). Although several sorption mechanisms have been reported by different researchers, the four dominant HM removal mechanisms are (Qian et al., 2015; Reesa et al., 2014; Li et al., 2017): (i) Electrostatic attraction between positively charged metal ions and negatively charged biochar surface - the larger surface area and higher surface energy are helpful for biochars to strongly absorb the HM ions and remove them from the soil; (ii) Ion exchange between HM ions in soil and alkali and alkaline earth metals or protons on biochar surface - the higher the cation exchange capacity value, the stronger the retention of HMs; (iii) Complexation with $\pi$ electron- or surface functional groups (e.g. - $\mathrm{COOH}$, $-\mathrm{OH}$ and $\mathrm{NH}_{2}$ ) - complexation is significant for the fixation of $\mathrm{HM}$ ions with strong affinity; and (iv) Co- 
precipitation to form insoluble compounds. Addition of biochar can increase the $\mathrm{pH}$ of the soil, and the reaction of $\mathrm{HM}$ ions with $-\mathrm{OH}, \mathrm{PO}_{4}{ }^{3-}, \mathrm{CO}_{3}{ }^{2-}$ can form hydroxide, carbonate or phosphate precipitation, which effectively solidifies HM pollutants. The sorption interaction of HM ions with biochar is influenced by pyrolysis temperature, feedstock type, $\mathrm{pH}$ of soil and biochar, physical and chemical properties of HM ions, and application rate (Patel et al., 2018; Wang et al., 2020; Oliveira et al., 2017). In comparison, five dominant PAH-remediation mechanisms are mediated by biochar (Wang et al., 2020; Oliveira et al., 2017), and these are: (i) Pore-filling, where sorption capacity is directly proportional to the micropores' surface area; (ii) Hydrophobic effect, which relates to the reduction of $\mathrm{H}$ - and O-containing functional groups on biochar during pyrolysis enhance its hydrophobicity and improve sorption efficiency; (iii) Electrostatic attraction, which is governed mainly by interactions via $\pi-\pi$ electron donor-acceptor; (iv) Hydrogen bonds, mainly intermolecular hydrogen bonds between $\mathrm{H}$ atom and $\mathrm{COOH}, \mathrm{OH}$, and $\mathrm{R}-\mathrm{OH}$ functional groups on biochar surface and (v) Partitioning, where the non-carbonised organic matrix of biochar initiates partitioning of PAHs due to reduction of substrate polarity. The sorption ability of biochar and its interactions with PAHs are influenced by several factors. Typical factors influencing sorption interactions between biochar and pollutants include $\mathrm{pH}$, pyrolysis temperature, feedstock type and ratios of pollutant-tobiochar (Patel et al., 2018). Given the aforementioned remediation mechanisms of biochar, many studies have reported positive results of biochar application in removing of HM and PAH pollutants (Table 3). However, remediation work involving biochar alone could require more time and/or larger quantities of biochar to be effective in removing certain pollutants (selective adsorption) compared to (bio)engineered biochar. Selective adsorption as a result of competition among HM ions and/or PAH compounds for binding sites on biochar may favour pollutants sequestration over others (Mahdi et al., 2019). The outcompeted pollutants could possibly be accommodated via other remediation agent or material engineered with biochar to provide a wider range of binding sites. For example, in a multicomponent system, the adsorption of $\mathrm{Pb}^{2+}, \mathrm{Cu}^{2+}$, and $\mathrm{Ni}^{2+}$ by date seed biochar exhibited competitive behaviour. Compared to single component systems, the adsorption capacities of each ion 
were reduced by 48-75\% in both batch and column experiments (Mahdi et al., 2019). Park et al., (2016) reported maximum adsorption capacities $\left(\mathrm{mg} \mathrm{g}^{-1}\right)$ of metals by sesame straw biochar which were in the order of $\mathrm{Pb}(102)>\mathrm{Cd}(86)>\mathrm{Cr}(65)>\mathrm{Cu}(55)>\mathrm{Zn}$ (34) in the mono-metal adsorption isotherm and $\mathrm{Pb}(88)>\mathrm{Cu}(40)>\mathrm{Cr}(21)>\mathrm{Zn}(7)>\mathrm{Cd}(5)$ in the multi-metal adsorption isotherm. In this case, the amalgamation of biochar with hydrogel, digestate and bioaugmentation, respectively, could speed up the process of removing these pollutants, reduce the amount of biochar usage, and further result in remediating other types of recalcitrant pollutants. As shown in Table 4, HMs/PAHs remediation mechanisms of hydrogel include complexation, ion exchange, chelation, and electrostatic attraction. Similarly, dominant remediation mechanisms of digestate and bioaugmentation include precipitation, ion exchange, electrostatic interaction, complexation, redox reaction, and Van der Waals forces. Although digestate does not directly remove pollutants, it acts as a carrier of exogenous microorganism. Also, it acts as a source of nutrients, thus promoting microbial diversity and abundance, which the microorganisms, in turn, remove the pollutants. 
Table 4. Remediation of HMs and PAHs by different methods

\begin{tabular}{|c|c|c|c|c|}
\hline Technique & Mechanism & Ref & Remediation efficiency of HMs and PAHs removal & Ref \\
\hline \multirow{2}{*}{ Biochar } & \multirow{2}{*}{$\begin{array}{l}\text { Physical adsorption, ion exchange, electrostatic } \\
\text { interaction, complexation, precipitation, } \\
\text { hydrophobic effect, hydrogen bond and pore-filling }\end{array}$} & \multirow{2}{*}{$\begin{array}{l}\text { Xie et al., } \\
2015 ; \text { Zhou } \\
\text { et al., 2018; } \\
\text { Beesley et } \\
\text { al., } 2014\end{array}$} & $\begin{array}{l}\text { Biochar decreased } \mathrm{Cd} \text { and } \mathrm{Zn} \text { content by } 99 \% \text { compared to untreated soil and } \\
\text { significantly increased biomass }\end{array}$ & $\begin{array}{l}\text { Brendova } \\
\text { et al., } 2015\end{array}$ \\
\hline & & & $\begin{array}{l}\text { Biochar reduced PAHs in coal contaminated soil by } 86 \% \text { and reduced } \\
\text { bioaccessible PAHs by almost } 100 \% \text { compared with the untreated soil }\end{array}$ & $\begin{array}{l}\text { Kołtowski } \\
\text { et al., } 2016\end{array}$ \\
\hline \multirow[b]{2}{*}{ Hydrogel } & \multirow{2}{*}{$\begin{array}{l}\text { Chemisorption, complexation, adsorption on } \\
\text { surface and pores, ion exchange, chelation, } \\
\text { adsorption by physical forces, electrostatic } \\
\text { interactions, and entrapment in inter- and intra- } \\
\text { fibrillar capillaries and spaces of the structural } \\
\text { polysaccharide network, }\end{array}$} & \multirow{2}{*}{$\begin{array}{l}\text { Omidian et } \\
\text { al., 2015; } \\
\text { Ahmed, } \\
2015 ; \\
\text { Adjary et } \\
\text { al., 2020Pan }\end{array}$} & $\begin{array}{l}\text { A lignin-based poly(acrylic acid) hydrogel showed a reduction in } \mathrm{Cu}, \mathrm{Zn}, \mathrm{Cd} \\
\text { and } \mathrm{Pb} \text { concentrations by } 23 \%, 53 \%, 14 \% \text { and } 18 \% \text {, respectively }\end{array}$ & $\begin{array}{l}\text { Zhao, } \\
2019\end{array}$ \\
\hline & & & $\begin{array}{l}\text { Poly(vinyl alcohol)/chitosan/maleic anhydride- } \beta \text {-cyclodextrin hydrogels } \\
\text { reduced PAHs concentrations by } 43 \%, 69 \% \text {, and } 19 \% \text { for low, intermediate, } \\
\text { and high swelling hydrogels, respectively }\end{array}$ & $\begin{array}{l}\text { Filho et al., } \\
2020\end{array}$ \\
\hline \multirow[b]{2}{*}{ Digestate } & \multirow{2}{*}{$\begin{array}{l}\text { Slight alkaline property neutralises acidic soil thus } \\
\text { enhance immobilisation of pollutants. Acts as a } \\
\text { source of nutrient, carbon and microorganisms. } \\
\text { Hence, promote microbial activity and } \\
\text { immobilisation of pollutants }\end{array}$} & \multirow{2}{*}{$\begin{array}{l}\text { Smith et al., } \\
2010 \text {; Zeng } \\
\text { et al., } 2015\end{array}$} & $\begin{array}{l}\text { Application of digestate showed a significant reduction in concentrations of } \\
\mathrm{Cu}, \mathrm{Zn}, \mathrm{Fe}, \mathrm{Pb} \text { and } \mathrm{Cr} \text { in the mining soil }\end{array}$ & $\begin{array}{l}\text { Guo et al., } \\
2020\end{array}$ \\
\hline & & & $\begin{array}{l}\text { Application of digestate (OFMSW) to petroleum-contaminated soil revealed } \\
\text { a high proportion of } a l k B \text { genes with diesel removal efficiency rate of } 78 \%\end{array}$ & $\begin{array}{l}\text { Gielnik et } \\
\text { al., } 2019 \\
\text { a,b }\end{array}$ \\
\hline \multirow[t]{2}{*}{ Bioaugmentation } & \multirow{2}{*}{$\begin{array}{l}\text { Precipitation, chemical adsorption, ion exchange, } \\
\text { electrostatic interaction, complexation, covalent } \\
\text { bonding and redox reaction and van der Waals } \\
\text { Force }\end{array}$} & \multirow{2}{*}{$\begin{array}{l}\text { Agnello et } \\
\text { al., 2016; } \\
\text { Rajendra, } \\
2003\end{array}$} & $\begin{array}{l}\text { Bacillus subtilis efficiently immobilised } \mathrm{Cr}, \mathrm{Cu} \text { and } \mathrm{Zn} \text { in contaminated soil, } \\
\text { transforming from bioavailable-fraction (high-mobility) (60-90\% reduction) } \\
\text { to residual-fraction (low-mobility) (50-80\% increment). Increased urease and } \\
\text { dehydrogenase activities by } 41 \% \text { and } 8 \% \text { ) respectively, compared to control }\end{array}$ & $\begin{array}{l}\text { Maity et } \\
\text { al., } 2019\end{array}$ \\
\hline & & & $\begin{array}{l}\text { Pseudomonas aeruginosa degraded fluorene, phenanthrene and pyrene with } \\
\text { the efficiency of } 96 \%, 50 \% \text { and } 41 \% \text {, respectively, at initial concentrations of } \\
20 \mathrm{mg} \mathrm{L}^{-1} \text { in seven days }\end{array}$ & $\begin{array}{l}\text { Medic et } \\
\text { al., } 2020\end{array}$ \\
\hline
\end{tabular}




\section{Biochar/Digestate-Based Circular Bioeconomy}

Conversion of waste to biochar and digestate is a sustainable pathway to circular bioeconomy (Hu et al., 2020). Circular bioeconomy can be defined as the exploration and exploitation of waste bioresources, which involves the use of biotechnology to convert into bio-products of economic value in a sustainable manner (Bugge et al., 2016; Stegmann, et al., 2020). In this case, biomass material from agricultural wastes is the bio-resource while the resultant biochar/digestate is the bio-product. The biochar/digestate can be used for agricultural and environmental applications with added economical value (Figure 4). This concept in principle promotes sustainability compared to the traditional 'takemake-dispose' linear model. Essentially, the production, marketing, awareness campaigns and commercialization activities of converting the waste bio-resource into a valuable bio-product are imperative for the sustainability of bioeconomy (Oni et al., 2019). All these activities in bioeconomy is an avenue for employment opportunities both direct and indirect employment. Several reviews (e.g. Dahal et al., 2018; Oni et al., 2019; Jindo et al. 2020) have been published addressing utilisation of biochar in agriculture and environment including its implications in promoting a circular bioeconomy framework.

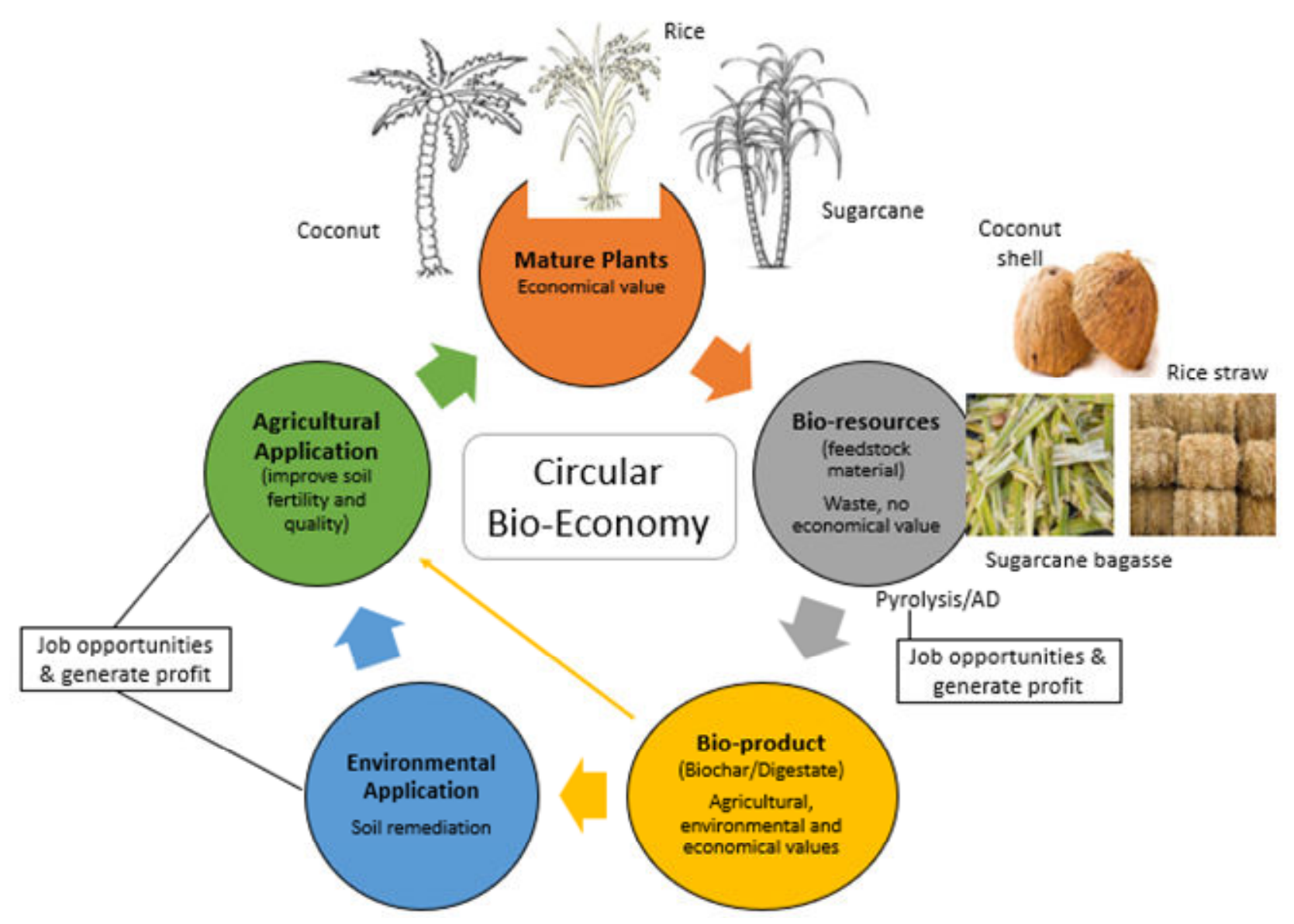

Figure 4. Promoting circular bioeconomy via use of biochar for decontamination 


\section{Large-Scale Field Application and Challenges}

Biochar adsorptive studies at laboratory (Alaboudi et al., 2019), greenhouse (Khan et al, 2015) and small-scale field trials (Nie et al., 2018) have shown great potential. But challenges remain in terms of practicality, effectiveness, cost and sustainability at large-scale field application at commercial levels. Large-scale field trials are essential before implementation of operational scale remediation projects (Zhang et al., 2013; Antonangelo and Zhang, 2020). One of the key challenges associated with large-scale filed trials is to achieve comparable or better remediation results compared to smallscale experiments considering the prevailing real-world environmental parameters. At small-scale, experimental and environmental parameters are controlled, therefore, the result does not necessarily mimic the real-world field conditions (Van Zwieten et al., 2010; Beesley et al., 2010). Cost involved in up-scaling of project is another factor. The cost associated with production (raw biowaste and pyrolysis), transportation (raw biowaste and biochar), equipment purchases, and biochar application presents a major hurdle in the implementation of large-scale field applications (Xiao et al., 2020; Marousěk et al. 2017; Shackley et al., 2011). Typical reported production costs range between $\$ 222$ and $\$ 584$ ton $^{-1}$ (Huang et al. 2014; Shabangu et al. 2014), while the profit made in improving soil condition is only of $\$ 96.13$ ton $^{-1}$ (Campbell et al. 2018). Thus, this calls for a sustainable approach to mitigate economical infeasibility of biochar usage for soil remediation. However, due to limited largescale field trials of biochar, little findings are available to understand commercial sustainability of its application (Fytili and Zabaniotou, 2018). Most authors understand the improvement in the biochar economy in the perspective of proposing new types of cheaper feedstock instead of as a purposegrown biomass (El-Naggar et al. 2019). Few others (e.g. Zhou et al., 2019) support the idea of employing new pyrolysis methods (e.g. wet pyrolysis) for producing tailored made biochars at lowcost compared to traditional high energy consumption pyrolysis method. An option would be to combine different strategies to address economic feasibility and practicality. For instance:

- Utilise free or cheap readily and locally available waste biomass with high remediation efficiency,

- The selected biomass should require trivial or no artificial fertilisation and herbicide/pesticide treatments to grow in large quantities,

- The selected biomass should generate profit by marketing certain edible parts of the plant, while the non-edible parts could be used for biochar production,

- Employ low-cost carbonisation method,

- The biochar should be produced in the vicinity of the feedstock production area or within its application site to reduce logistical costs, 
- Biochar derived from the selected biomass feedstock should have good regeneration and reusability cycles, and

- Combine biochar with other cheap adsorbent or degradation material/organisms to reduce cost and enhance remediation performance

Although the biochar price is proportional to labour cost, it varies across the world. In general, global biochar price and labour cost are high in the USA and UK (about $500 \mathrm{USD} \mathrm{t}^{-1}$ ) and low in India and the Philippines (90 USD t ${ }^{-1}$ on average), thus, making biochar application more economically feasible for low income countries (Vochozka et al., 2016).

\section{Conclusion and Future Perspectives}

Biochar has the potential to be developed as a viable technology for remediation of co-contaminated soils. Numerous studies have shown that biochar can conceivably reduce the level of both HMs and PAHs in soil. In addition to biochar's function as a soil conditioner and sequester of greenhouse gases, it is sustainably economical and environmentally friendly, thus making it a suitable option over physical and chemical remediation technologies. The efficacy and effectiveness of biochar to remove contaminants from contaminated soil depends on the physicochemical properties of the biochar, which are influenced by the type of feedstock (biomass) material, type of carbonisation method used, and pyrolysis conditions employed. However, the efficacy of biochar to remediate contaminants can potentially be improved with specific engineered modifications of the biochar. In conclusion, this review has provided a positive outlook for the implementation of biochar and enhanced biochar remediation with hydrogel amendment, digestate amendment and microbial amendment, for remediation of HMs-PAHs co-contaminated soil. The prospect and research on biochar for soil treatment applications are reported in large quantities, but the study on soil application using the aforementioned engineered biochar amendments is a major knowledge gap at present. As a potential technology for remediation of contaminated soils, many aspects are still yet to be developed. Several knowledge gaps have been identified, and further research is required to close these gaps. 
- So far, studies that explore biochar and biochar composites for remediation of contaminated soils have mainly been conducted at the laboratory scale. Field-scale trials are essential before large-scale and operational scale remediation projects are implemented

- The biochar characteristics vary with different biomass materials and pyrolysis conditions. It is important to optimise production systems to produce tailored biochar with desired characteristics to effectively remediate co-contaminated soil with HMs and PAHs

- The capacity of biochar to adsorb or sequester pollutants increases with time, reaching an equilibrium and then decreasing due to the ageing process. Additional understanding of the ageing process is required to provide a better understanding of the long-term environmental fate of the sequestered contaminants, biochar application rate and frequency to improve remediation efficiency

- An optimised hydrogel can effectively immobilise HMs and PAHs. Little, however, is known about the synergic adsorption efficiency of amalgamating biochar with desired optimised hydrogels (i.e. as a biochar-hydrogel composite).

- Several studies have shown that biochar and digestate promote immobilization of pollutants. However, limited studies have demonstrated that biochar-digestate composite improves microbial population, diversity and activity in the soil, and reducing the total and bioavailable concentrations of HMs and PAHs in situ

- Inoculation of microorganisms (bioaugmentation) with biochar has shown promising results for cleaning up soils contaminated with HMs and PAHs. Selection of suitable metal removal and PAHs degradation microorganisms and their consortia could be a challenge. Also, there is a need in finding sources of microbial agents able to degrade PAHs which may serve as species pools for enrichments during inoculum preparation

- Short term and long-term effects of biochar and biochar-based composites on soil physicochemical properties, and their influence in soil, need to be monitored and evaluated over time. 
- The regeneration of used biochar and biochar-based composites, and the possibility of its reusability and quality, must be assessed to achieve sustainability

- The addition of exogenous microorganisms has been shown to enhance the removal of pollutants in soil. However, it is important to perform initial characterisation of digestate microbiota (exogenous) to understand and compare the effects of exogenous and indigenous microorganisms after digestate application and during the remediation incubation period

\section{Acknowledgments}

J.A. is grateful for the Commonwealth $\mathrm{PhD}$ Scholarship Commission funded by the UK Department for International Development (DFID) United Kingdom (Award number PGCA-2019-100).

\section{Reference}

Abbas, S. H., Ismail, I. M., Mostafa, T. M., \& Sulaymon, A. H. (2014). Biosorption of heavy metals: a review. Journal of chemical science and technology, 3(4), 74-102.

Abbas, Z., Ali, S., Rizwan, M., Zaheer, I. E., Malik, A., Riaz, M. A., ... \& Al-Wabel, M. I. (2018). A critical review of mechanisms involved in the adsorption of organic and inorganic contaminants through biochar. Arabian Journal of Geosciences, 11(16), 448.

Abdelhafez, A. A., Li, J., \& Abbas, M. H. (2014). Feasibility of biochar manufactured from organic wastes on the stabilization of heavy metals in a metal smelter contaminated soil. Chemosphere, 117, 66-71.

Abdel-Shafy, H. I., \& Mansour, M. S. (2016). A review on polycyclic aromatic hydrocarbons: source, environmental impact, effect on human health and remediation. Egyptian Journal of Petroleum, 25(1), 107-123.

Abdi, O., \& Kazemi, M. (2015). A review study of biosorption of heavy metals and comparison between different biosorbents. J Mater Environ Sci, 6(5), 1386-1399.

Abedin, M. J., Cotter-Howells, J., \& Meharg, A. A. (2002). Arsenic uptake and accumulation in rice (Oryza sativa L.) irrigated with contaminated water. Plant and soil, 240(2), 311-319.

Abeer, M. M., Amin, M. C. I. M., Lazim, A. M., Pandey, M., \& Martin, C. (2014). Synthesis of a novel acrylated abietic acid-g-bacterial cellulose hydrogel by gamma irradiation. Carbohydrate polymers, $110,505-512$.

Abia, A. A., \& Igwe, J. C. (2005). Sorption kinetics and intraparticulate diffusivities of $\mathrm{Cd}, \mathrm{Pb}$ and $\mathrm{Zn}$ ions on maize cob. African Journal of Biotechnology, 4(6), 509-512.

Agnello, A. C., Bagard, M., van Hullebusch, E. D., Esposito, G., \& Huguenot, D. (2016). Comparative bioremediation of heavy metals and petroleum hydrocarbons co-contaminated soil by natural attenuation, phytoremediation, bioaugmentation and bioaugmentation-assisted phytoremediation. Science of the Total Environment, 563, 693-703.

Ahmad, I., Akhtar, M. J., Zahir, Z. A., \& Jamil, A. (2012). Effect of cadmium on seed germination and seedling growth of four wheat (Triticum aestivum L.) cultivars. Pak. J. Bot, 44(5), 1569-1574. 
Ahmad, M., Ok, Y. S., Rajapaksha, A. U., Lim, J. E., Kim, B. Y., Ahn, J. H., ... \& Lee, S. S. (2016). Lead and copper immobilization in a shooting range soil using soybean stover-and pine needle-derived biochars: Chemical, microbial and spectroscopic assessments. Journal of Hazardous Materials, 301, 179-186.

Ahmed, E. M. (2015). Hydrogel: Preparation, characterization, and applications: A review. Journal of advanced research, 6(2), 105-121.

Ajdary, R., Tardy, B. L., Mattos, B. D., Bai, L., \& Rojas, O. J. (2020). Plant Nanomaterials and Inspiration from Nature: Water Interactions and Hierarchically Structured Hydrogels. Advanced Materials, 2001085.

Alaboudi, K. A., Ahmed, B., \& Brodie, G. (2019). Effect of biochar on Pb, Cd and Cr availability and maize growth in artificial contaminated soil. Annals of Agricultural Sciences, 64(1), 95-102.

Ali, H., Khan, E., \& Sajad, M. A. (2013). Phytoremediation of heavy metals-concepts and applications. Chemosphere, 91(7), 869-881.

Ali, A. Y., Idris, A. M., Ebrahim, A. M., \& Eltayeb, M. A. (2017). Brown algae (Phaeophyta) for monitoring heavy metals at the Sudanese Red Sea coast. Applied water science, 7(7), 3817-3824.

Ali, H., Khan, E., \& Ilahi, I. (2019). Environmental chemistry and ecotoxicology of hazardous heavy metals: environmental persistence, toxicity, and bioaccumulation. Journal of chemistry, 2019. Article ID: 6730305

Alvarez, A., Saez, J. M., Costa, J. S. D., Colin, V. L., Fuentes, M. S., Cuozzo, S. A., ... \& Amoroso, M. J. (2017). Actinobacteria: current research and perspectives for bioremediation of pesticides and heavy metals. Chemosphere, 166, 41-62.

Amstaetter, K., Eek, E., \& Cornelissen, G. (2012). Sorption of PAHs and PCBs to activated carbon: Coal versus biomass-based quality. Chemosphere, 87(5), 573-578.

Anawar, H. M., Akai, J., Mostofa, K. M. G., Safiullah, S., \& Tareq, S. M. (2002). Arsenic poisoning in groundwater: health risk and geochemical sources in Bangladesh. Environment International, 27(7), 597-604.

Andersson, J. T., \& Achten, C. (2015). Time to say goodbye to the 16 EPA PAHs? Toward an up-to-date use of PACs for environmental purposes. Polycyclic Aromatic Compounds, 35(2-4), 330-354.

Annabi, N., Tamayol, A., Uquillas, J. A., Akbari, M., Bertassoni, L. E., Cha, C., ... \& Khademhosseini, A. (2014). 25th anniversary article: Rational design and applications of hydrogels in regenerative medicine. Advanced materials, 26(1), 85-124.

Antonangelo, J. A., \& Zhang, H. (2020). The Use of Biochar as a Soil Amendment to Reduce

Potentially Toxic Metals (PTMs) Phytoavailability. In Applications of Biochar for Environmental

Safety. IntechOpen.

Anyanwu, I. N., Alo, M. N., Onyekwere, A. M., Crosse, J. D., Nworie, O., \& Chamba, E. B. (2018). Influence of biochar aged in acidic soil on ecosystem engineers and two tropical agricultural plants. Ecotoxicology and environmental safety, 153, 116-126.

Askari, F., Nafisi, S., Omidian, H., \& Hashemi, S. A. (1993). Synthesis and characterization of acrylicbased superabsorbents. Journal of applied polymer science, 50(10), 1851-1855.

Aspray, T. J., Dimambro, M., \& Steiner, J. (2017). Investigation into plastic in food waste derived digestate and soil. DOI: https://www.sepa.org.uk/media/327640/investigation-into-plastic-in-foodwaste-derived-digestate-and-soil.pdf accessed on 26/06/2020

Astrini, N., Anah, L., \& Haryadi, H. R. (2015). Adsorption of heavy metal ion from aqueous solution by using cellulose based hydrogel composite. In Macromolecular symposia, 353 (1), pp. 191-197).

Agency for Toxic Substances and Disease Registry (ATSDR). (1995). Toxicological profile for Polycyclic Aromatic Hydrocarbons (PAHs). Atlanta, GA: U.S. Department of Health and Human 
Services, Public Health Service. DOI: https://www.atsdr.cdc.gov/toxprofiles/tp.asp?id=122\&tid=25 accessed on 25/07/2020

Agency for Toxic Substance and Disease Registry (ATSDR). (2004). Toxicological profiles. Atlanta: U.S. Department of Health and Human Services, Public Health Services. Retrieved 1 December 2007. DOI: http://www.atsdr.cdc.gov/toxprofiles/tp13.pdf accessed on 24/04/2020

ATSDR. (2007). Toxicological profiles. Atlanta: U.S. Department of Health and Human Services, Public Health Services. DOI: http://www.atsdr.cdc.gov/toxprofiles/tp13.pdf accessed 18/04/2020

Atkinson, R., \& Arey, J. (1994). Atmospheric chemistry of gas-phase polycyclic aromatic hydrocarbons: formation of atmospheric mutagens. Environmental health perspectives, 102(suppl 4), 117-126.

Awofolu, O. R. (2005). A survey of trace metals in vegetation, soil and lower animal along some selected major roads in metropolitan city of Lagos. Environmental monitoring and Assessment, 105(1-3), 431447.

Azubuike, C. C., Chikere, C. B., \& Okpokwasili, G. C. (2016). Bioremediation techniques-classification based on site of application: principles, advantages, limitations and prospects. World Journal of Microbiology and Biotechnology, 32(11), 180.

Badiger, M. V., McNeill, M. E., \& Graham, N. B. (1993). Porogens in the preparation of microporous hydrogels based on poly (ethylene oxides). Biomaterials, 14(14), 1059-1063.

Barka, E. A., Vatsa, P., Sanchez, L., Gaveau-Vaillant, N., Jacquard, C., Klenk, H. P., ... \& van Wezel, G. P. (2016). Taxonomy, physiology, and natural products of Actinobacteria. Microbiology and Molecular Biology Reviews, 80(1), 1-43.

Barnes, J. L., Zubair, M., John, K., Poirier, M. C., \& Martin, F. L. (2018). Carcinogens and DNA damage. Biochemical Society Transactions, 46(5), 1213-1224.

Barrachina, A. C., Carbonell, F. B., \& Beneyto, J. M. (1995). Arsenic uptake, distribution, and accumulation in tomato plants: effect of arsenite on plant growth and yield. Journal of plant nutrition, 18(6), 1237-1250.

Beesley, L., Moreno-Jiménez, E., \& Gomez-Eyles, J. L. (2010). Effects of biochar and greenwaste compost amendments on mobility, bioavailability and toxicity of inorganic and organic contaminants in a multi-element polluted soil. Environmental pollution, 158(6), 2282-2287.

Beesley, L., Moreno-Jiménez, E., Gomez-Eyles, J. L., Harris, E., Robinson, B., \& Sizmur, T. (2011). A review of biochars' potential role in the remediation, revegetation and restoration of contaminated soils. Environmental pollution, 159(12), 3269-3282.

Beesley, L., Inneh, O. S., Norton, G. J., Moreno-Jimenez, E., Pardo, T., Clemente, R., \& Dawson, J. J. (2014). Assessing the influence of compost and biochar amendments on the mobility and toxicity of metals and arsenic in a naturally contaminated mine soil. Environmental Pollution, 186, 195-202.

Bekin, S., Sarmad, S., Gürkan, K., Keçeli, G., \& Gürdağ, G. (2014). Synthesis, characterization and bending behavior of electroresponsive sodium alginate/poly (acrylic acid) interpenetrating network films under an electric field stimulus. Sensors and Actuators B: Chemical, 202, 878-892.

Bian, R., Chen, D., Liu, X., Cui, L., Li, L., Pan, G., ... \& Chang, A. (2013). Biochar soil amendment as a solution to prevent Cd-tainted rice from China: results from a cross-site field experiment. Ecological engineering, 58, 378-383.

Bian, R., Joseph, S., Cui, L., Pan, G., Li, L., Liu, X., ... \& Marjo, C. (2014). A three-year experiment confirms continuous immobilization of cadmium and lead in contaminated paddy field with biochar amendment. Journal of hazardous materials, 272, 121-128.

Bianco, F., Race, M., Papirio, S., \& Esposito, G. (2020). Removal of polycyclic aromatic hydrocarbons during anaerobic biostimulation of marine sediments. Science of The Total Environment, 709, 136141. 
Biogreen. (2020). Think Sustainable: Pyrolysis, torrefaction, gasification process for biomas waste. DOI: http://www.biogreen-energy.com/ accessed 26/06/2020

Braghiroli, F. L., Bouafif, H., \& Koubaa, A. (2019). Enhanced SO2 adsorption and desorption on chemically and physically activated biochar made from wood residues. Industrial Crops and Products, 138, 111456.

Broniatowski, M., Binczycka, M., Wójcik, A., Flasiński, M., \& Wydro, P. (2017). Polycyclic aromatic hydrocarbons in model bacterial membranes-Langmuir monolayer studies. Biochimica et Biophysica Acta (BBA)-Biomembranes, 1859(12), 2402-2412.

Břendová, K., Tlustoš, P., \& Száková, J. (2015). Biochar immobilizes cadmium and zinc and improves phytoextraction potential of willow plants on extremely contaminated soil. Plant, Soil and Environment, 61(7), 303-308.

Bruun, E. W., Ambus, P., Egsgaard, H., \& Hauggaard-Nielsen, H. (2012). Effects of slow and fast pyrolysis biochar on soil C and N turnover dynamics. Soil Biology and Biochemistry, 46, 73-79.

Buenger, D., Topuz, F., \& Groll, J. (2012). Hydrogels in sensing applications. Progress in Polymer Science, 37(12), 1678-1719.

Bugge, M. M., Hansen, T., \& Klitkou, A. (2016). What is the bioeconomy? A review of the literature. Sustainability, 8(7), 691.

Buss, W., Mašek, O., Graham, M., \& Wüst, D. (2015). Inherent organic compounds in biochar-their content, composition and potential toxic effects. Journal of Environmental Management, 156, 150157.

Buss, W., Graham, M. C., MacKinnon, G., \& Mašek, O. (2016). Strategies for producing biochars with minimum PAH contamination. Journal of Analytical and Applied Pyrolysis, 119, 24-30.

Butylina, S., Geng, S., \& Oksman, K. (2016). Properties of as-prepared and freeze-dried hydrogels made from poly (vinyl alcohol) and cellulose nanocrystals using freeze-thaw technique. European Polymer Journal, 81, 386-396.

Campbell, R. M., Anderson, N. M., Daugaard, D. E., \& Naughton, H. T. (2018). Financial viability of biofuel and biochar production from forest biomass in the face of market price volatility and uncertainty. Applied energy, 230, 330-343.

Cao, X., Ma, L. Q., Rhue, D. R., \& Appel, C. S. (2004). Mechanisms of lead, copper, and zinc retention by phosphate rock. Environmental pollution, 131(3), 435-444.

Cao, Z., Guo, J., Fan, X., Xu, J., Fan, Z., \& Du, B. (2011). Detection of heavy metal ions in aqueous solution by P (MBTVBC-co-VIM)-coated QCM sensor. Sensors and Actuators B: Chemical, 157(1), 34-41.

Cao, Y., Yang, B., Song, Z., Wang, H., He, F., \& Han, X. (2016). Wheat straw biochar amendments on the removal of polycyclic aromatic hydrocarbons (PAHs) in contaminated soil. Ecotoxicology and Environmental Safety, 130, 248-255.

Cave, M. R., Wragg, J., Harrison, I., Vane, C. H., Wiele, T. V. D., Groeve, E. D., ... \& Daly, P. (2010). Comparison of batch mode and dynamic physiologically based bioaccessibility tests for PAHs in soil samples. Environmental science \& technology, 44(7), 2654-2660.

Cervantes, C., Campos-García, J., Devars, S., Gutiérrez-Corona, F., Loza-Tavera, H., Torres-Guzmán, J. C., \& Moreno-Sánchez, R. (2001). Interactions of chromium with microorganisms and plants. FEMS microbiology reviews, 25(3), 335-347.

Chabukdhara, M., Gupta, S. K., \& Gogoi, M. (2017). Phycoremediation of heavy metals coupled with generation of bioenergy. In Algal Biofuels (pp. 163-188). Springer, Cham. DOI: https://doi.org/10.1007/978-3-319-51010-1_9 accessed on 23/05/2020

Chai, Q., Jiao, Y., \& Yu, X. (2017). Hydrogels for biomedical applications: their characteristics and the mechanisms behind them. Gels, 3(1), 6 . 
Chang, J., Yang, Q., Dong, J., Ji, B., Si, G., He, F., ... \& Chen, J. (2019). Reduction in Hg phytoavailability in soil using Hg-volatilizing bacteria and biochar and the response of the native bacterial community. Microbial biotechnology, 12(5), 1014-1023.

Chatterjee, S., Chatterjee, T., \& Woo, S. H. (2010). A new type of chitosan hydrogel sorbent generated by anionic surfactant gelation. Bioresource technology, 101(11), 3853-3858.

Chen, B., Chen, Z., \& Lv, S. (2011). A novel magnetic biochar efficiently sorbs organic pollutants and phosphate. Bioresource technology, 102(2), 716-723.

Chen, Baoliang, Miaoxin Yuan, and Linbo Qian. (2012). Enhanced bioremediation of PAH-contaminated soil by immobilized bacteria with plant residue and biochar as carriers. Journal of Soils and Sediments, 1350-1359.

Chen, J. J., Ahmad, A. L., \& Ooi, B. S. (2013). Poly (N-isopropylacrylamide-co-acrylic acid) hydrogels for copper ion adsorption: Equilibrium isotherms, kinetic and thermodynamic studies. Journal of Environmental Chemical Engineering, 1(3), 339-348.

Chen, M., Xu, P., Zeng, G., Yang, C., Huang, D., \& Zhang, J. (2015). Bioremediation of soils contaminated with polycyclic aromatic hydrocarbons, petroleum, pesticides, chlorophenols and heavy metals by composting: applications, microbes and future research needs. Biotechnology advances, 33(6), 745-755.

Chen, D., Guo, H., Li, R., Li, L., Pan, G., Chang, A., \& Joseph, S. (2016). Low uptake affinity cultivars with biochar to tackle Cd-tainted rice-a field study over four rice seasons in Hunan, China. Science of the Total Environment, 541, 1489-1498.

Chen, Q., Zhang, X., Liu, Y., Wei, J., Shen, W., Shen, Z., \& Cui, J. (2017). Hemin-mediated alleviation of zinc, lead and chromium toxicity is associated with elevated photosynthesis, antioxidative capacity; suppressed metal uptake and oxidative stress in rice seedlings. Plant Growth Regulation, 81(2), 253264.

Chen, H., Osman, A. I., Mangwandi, C., \& Rooney, D. (2019a). Upcycling food waste digestate for energy and heavy metal remediation applications. Resources, Conservation \& Recycling: X, 3, 100015.

Chen, H., Zhang, J., Tang, L., Su, M., Tian, D., Zhang, L., ... \& Hu, S. (2019b). Enhanced Pb immobilization via the combination of biochar and phosphate solubilizing bacteria. Environment International, 127, 395-401.

Chen, X., He, H. Z., Chen, G. K., \& Li, H. S. (2020). Effects of biochar and crop straws on the bioavailability of cadmium in contaminated soil. Scientific Reports, 10(1), 1-12.

Cheng, S., Chen, T., Xu, W., Huang, J., Jiang, S., \& Yan, B. (2020). Application research of biochar for the remediation of soil heavy metals contamination: a review. Molecules, 25(14), 3167.

Chibuike, G. U., \& Obiora, S. C. (2014). Heavy metal polluted soils: effect on plants and bioremediation methods. Applied and environmental soil science, 2014.

Choi, H., Harrison, R., Komulainen, H., \& Delgado Saborit, J. (2010). Polycyclic aromatic hydrocarbons. WHO Guidelines for Indoor Air Quality: Selected Pollutants. Geneva: World Health Organization. DOI: https://www.ncbi.nlm.nih.gov/books/NBK138709 accessed on 23/03/2020

Cipullo, S., Negrin, I., Claveau, L., Snapir, B., Tardif, S., Pulleyblank, C., ... \& Coulon, F. (2019). Linking bioavailability and toxicity changes of complex chemicals mixture to support decision making for remediation endpoint of contaminated soils. Science of the Total Environment, 650, 2150-2163.

Cong, H., Mašek, O., Zhao, L., Yao, Z., Meng, H., Hu, E., \& Ma, T. (2018). Slow pyrolysis performance and energy balance of corn stover in continuous pyrolysis-based poly-generation systems. Energy \& Fuels, 32(3), 3743-3750.

Cook, T. (2019). How are microplastics transported to polar regions?, Eos, 100, https://doi.org/10.1029/2019EO134237. Published on 26 September 2019. Accessed 17/04/2020 
Coviello, T., Matricardi, P., Marianecci, C., \& Alhaique, F. (2007). Polysaccharide hydrogels for modified release formulations. Journal of controlled release, 119(1), 5-24.

Crisler, G. B., Burk, G. A., Simmons, P., Quigley, M., \& Mlsna, T. (2020). Lead removal using biochars obtained from slow pyrolysis of dry and water-soaked pecan shell biomass. Separation Science and Technology, 55(11), 1947-1956.

Cristaldi, A., Conti, G. O., Jho, E. H., Zuccarello, P., Grasso, A., Copat, C., \& Ferrante, M. (2017). Phytoremediation of contaminated soils by heavy metals and PAHs. A brief review. Environmental Technology \& Innovation, 8, 309-326.

Crombie, K., Mašek, O., Sohi, S. P., Brownsort, P., \& Cross, A. (2013). The effect of pyrolysis conditions on biochar stability as determined by three methods. Gcb Bioenergy, 5(2), 122-131.

Cross, A., \& Sohi, S. P. (2011). The priming potential of biochar products in relation to labile carbon contents and soil organic matter status. Soil biology and biochemistry, 43(10), 2127-2134.

Dahal, R. K., Acharya, B., \& Farooque, A. (2018). Biochar: a sustainable solution for solid waste management in agro-processing industries. Biofuels, 1-9.

Das, N., Vimala, R., \& Karthika, P. (2008). Biosorption of heavy metals-an overview. Indian Journal of Biotechnology, 7, 159-169.

Dean, J. R., \& Scott, W. C. (2004). Recent developments in assessing the bioavailability of persistent organic pollutants in the environment. TrAC Trends in Analytical Chemistry, 23(9), 609-618.

de Resende, M. F., Brasil, T. F., Madari, B. E., Netto, A. D. P., \& Novotny, E. H. (2018). Polycyclic aromatic hydrocarbons in biochar amended soils: Long-term experiments in Brazilian tropical areas. Chemosphere, 200, 641-648.

Deng, L., Liu, Y., \& Wang, W. (2020). Utilization of Digestate. In Biogas Technology (pp. 319-363). Springer, Singapore.

Dissanayake, P. D., Choi, S. W., Igalavithana, A. D., Yang, X., Tsang, D. C., Wang, C. H., ... \& Ok, Y. S. (2020). Sustainable gasification biochar as a high efficiency adsorbent for CO2 capture: A facile method to designer biochar fabrication. Renewable and Sustainable Energy Reviews, 124, 109785.

Dixit, R., Malaviya, D., Pandiyan, K., Singh, U. B., Sahu, A., Shukla, R., \& Paul, D. (2015). Bioremediation of heavy metals from soil and aquatic environment: an overview of principles and criteria of fundamental processes. Sustainability, 7(2), 2189-2212.

Dragan, E. S. (2014). Design and applications of interpenetrating polymer network hydrogels. A review. Chemical Engineering Journal, 243, 572-590.

Du, X., Zhu, Y. G., Liu, W. J., \& Zhao, X. S. (2005). Uptake of mercury (Hg) by seedlings of rice (Oryza sativa L.) grown in solution culture and interactions with arsenate uptake. Environmental and experimental botany, 54(1), 1-7.

Du, H., Shi, S., Liu, W., Teng, H., \& Piao, M. (2020). Processing and modification of hydrogel and its application in emerging contaminant adsorption and in catalyst immobilization: a review. Environmental Science and Pollution Research, 1-28.

Duan, W., Oleszczuk, P., Pan, B., \& Xing, B. (2019). Environmental behavior of engineered biochars and their aging processes in soil. Biochar, 1-13.

Dubrovskaya, E. V., Pozdnyakova, N. N., Muratova, A. Y., \& Turkovskaya, O. V. (2016). Changes in phytotoxicity of polycyclic aromatic hydrocarbons in the course of microbial degradation. Russian journal of plant physiology, 63(1), 172-179. 
Duxbury, C. L., Dixon, D. G., \& Greenberg, B. M. (1997). Effects of simulated solar radiation on the bioaccumulation of polycyclic aromatic hydrocarbons by the duckweed Lemna gibba. Environmental Toxicology and Chemistry: An International Journal, 16(8), 1739-1748.

Ehsan, M., Barakat, M. A., Husein, D. Z., \& Ismail, S. M. (2014). Immobilization of Ni and Cd in soil by biochar derived from unfertilized dates. Water, Air, \& Soil Pollution, 225(11), 2123.

El-Naggar, A., Lee, S. S., Rinklebe, J., Farooq, M., Song, H., Sarmah, A. K., ... \& Ok, Y. S. (2019). Biochar application to low fertility soils: a review of current status, and future prospects. Geoderma, 337, 536-554.

Engwa, G. A., Ferdinand, P. U., Nwalo, F. N., \& Unachukwu, M. N. (2019). Mechanism and health effects of heavy metal toxicity in humans. In Poisoning in the Modern World-New Tricks for an Old Dog? IntechOpen. DOI: https://doi.org/10.5772/intechopen.82511 accessed on 25/04/2020

Ejaz, A. (2016). Microbe-assisted remediation of lead, nickel and cadmium contaminated soil in association with biochar and okra (Abelmoschus esculentus L.).

FAO (Food and Agriculture Organization) of the United Nations. (2013). Food Wastage Footprint: Impacts on Natural Resources: Summary Report. FAO. DOI: https://www.researchgate.net/publication/262611961_Food_Wastage_Footprint_Impacts_on_Natural _Resources_Summary_Report accessed on 18/05/2020

Fashola, M. O., Ngole-Jeme, V. M., \& Babalola, O. O. (2016). Heavy metal pollution from gold mines: environmental effects and bacterial strategies for resistance. International journal of environmental research and public health, 13(11), 1047.

Fernández-Bayo, J. D., Achmon, Y., Harrold, D. R., McCurry, D. G., Hernandez, K., Dahlquist-Willard, R. M., ... \& Simmons, C. W. (2017). Assessment of two solid anaerobic digestate soil amendments for effects on soil quality and biosolarization efficacy. Journal of agricultural and food chemistry, 65(17), 3434-3442.

Filho, C.,M.,C., Bueno, P.,V.,A., Matsushita A.,F.,Y., Vilsinki, B.H., Rubira A.,F., Muniz, E.C., Murtinho, D.,M.,B., \& Valente, A.,J.,M. (2020). Uncommon sorption mechanisms of aromatic compounds onto poly(Vinyl Alcohol)/chitosan/maleic anhydride- $\beta$-cyclodextrin hydrogels. Polymers, 12,877

Fytili, D., \& Zabaniotou, A. (2018). Circular economy synergistic opportunities of decentralized thermochemical systems for bioenergy and biochar production fuelled with agro-industrial wastes with environmental sustainability and social acceptance: a review. Current Sustainable/Renewable Energy Reports, 5(2), 150-155.

Gao, Y., Zhou, D., Lyu, J., Sigen, A., Xu, Q., Newland, B., ... \& Wang, W. (2020). Complex polymer architectures through free-radical polymerization of multivinyl monomers. Nature Reviews Chemistry, $1-19$.

Garbisu, C., \& Alkorta, I. (2003). Basic concepts on heavy metal soil bioremediation. European Journal of Mineral Processing and Environmental Protection, 3(1), 58-66.

Garcia-Sánchez, M., Garcia-Romera, I., Cajthaml, T., Tlustoš, P., \& Száková, J. (2015). Changes in soil microbial community functionality and structure in a metal-polluted site: the effect of digestate and fly ash applications. Journal of environmental management, 162, 63-73.

Gentile, A. R. (2000). Down to earth: Soil degradation and sustainable development in Europe: A challenge for the 21st century (No. 16). European Communities. doi: https://www.eea.europa.eu/publications/Environmental_issue_series_16 accessed 23/04/2020

Ghayempour, S., \& Montazer, M. (2018). A modified microemulsion method for fabrication of hydrogel Tragacanth nanofibers. International journal of biological macromolecules, 115, 317-323. 
Gielnik, A., Pechaud, Y., Huguenot, D., Esposito, G., Guibaud, G., \& van Hullebusch, E. D. (2020a). Potential Use of Waste-to-Bioenergy By-Products in Bioremediation of Total Petroleum Hydrocarbons (TPH)-Contaminated Soils. In Environmental Soil Remediation and Rehabilitation (pp. 239-282). Springer, Cham. DOI: https://link.springer.com/chapter/10.1007/978-3-030-40348-5_5 accessed on $26 / / 06 / 2020$

Gielnik, A., Pechaud, Y., Huguenot, D., Cébron, A., Esposito, G., \& van Hullebusch, E. D. (2020b). Functional potential of sewage sludge digestate microbes to degrade aliphatic hydrocarbons during bioremediation of a petroleum hydrocarbons contaminated soil. Journal of Environmental Management, 111648.

Gielnik, A., Pechaud, Y., Huguenot, D., Cébron, A., Esposito, G., \& van Hullebusch, E. D. (2019a). Bacterial seeding potential of digestate in bioremediation of diesel contaminated soil. International Biodeterioration \& Biodegradation, 143, 104715.

Gielnik, A., Pechaud, Y., Huguenot, D., Cébron, A., Riom, J. M., Guibaud, G., ... \& van Hullebusch, E. D. (2019b). Effect of digestate application on microbial respiration and bacterial communities' diversity during bioremediation of weathered petroleum hydrocarbons contaminated soils. Science of the total environment, 670, 271-281.

Giri, S. K., Kumar, A., Raghuvanshi, A., \& Gulati, S., (2016). Effects of Polycyclic Aromatic Hydrocarbons on Environment and Health. Conference paper. DOI: https://www.researchgate.net/publication/301888451_Effects_of_Polycyclic_Aromatic_Hydrocarbon s_on_Environment_Health accessed on 20/07/2020

Gourdon, R., Bhende, S., Rus, E., \& Sofer, S. S. (1990). Comparison of cadmium biosorption by Grampositive and Gram-negative bacteria from activated sludge. Biotechnology letters, 12(11), 839-842.

Gwenzi, W., Chaukura, N., Noubactep, C., \& Mukome, F. N. (2017). Biochar-based water treatment systems as a potential low-cost and sustainable technology for clean water provision. Journal of environmental management, 197, 732-749.

Gutierrez, T. (2019). Occurrence and roles of the obligate hydrocarbonoclastic bacteria in the ocean when there is no obvious hydrocarbon contamination. Taxonomy, Genomics and Ecophysiology of Hydrocarbon-Degrading Microbes, 337-352.

Guo, M., He, Z., and Uchimiya, S. M. (2016). "Introduction to biochar as an agricultural and environmental amendment," in Agricultural and Environmental Applications of Biochar: Advances and Barriers. Vol. 63, eds M. Guo, Z. He, S. M. Uchimiya (Madison, WI: Soil Science Society of America), 1-14.

Guo, X., Xie, X., Liu, Y., Wang, C., Yang, M., \& Huang, Y. (2020). Effects of digestate DOM on chemical behaviour of soil heavy metals in an abandoned copper mining areas. Journal of Hazardous Materials, 122436.

Guo, M., Song, W., \& Tian, J. (2020). Biochar-facilitated soil remediation: mechanisms and efficacy variations. Frontiers in Environmental Science, 8, 183.

Hadia-e-Fatima, A. A. (2018). Heavy metal pollution-A mini review. J Bacteriol Mycol Open Access, 6(3), 179-181.

Hahladakis, J. N., Velis, C. A., Weber, R., Iacovidou, E., \& Purnell, P. (2018). An overview of chemical additives present in plastics: migration, release, fate and environmental impact during their use, disposal and recycling. Journal of hazardous materials, 344, 179-199.

Haleyur, N., Shahsavari, E., Jain, S. S., Koshlaf, E., Ravindran, V. B., Morrison, P. D., ... \& Ball, A. S. (2019). Influence of bioaugmentation and biostimulation on PAH degradation in aged contaminated soils: Response and dynamics of the bacterial community. Journal of environmental management, $238,49-58$.

Hamzenejad T., R., \& Sepehr, E. (2018). Heavy metals immobilization in contaminated soil by grapepruning-residue biochar. Archives of Agronomy and Soil Science, 64(8), 1041-1052. 
Han, F. X., Sridhar, B. M., Monts, D. L., \& Su, Y. (2004). Phytoavailability and toxicity of trivalent and hexavalent chromium to Brassica juncea. New Phytologist, 162(2), 489-499.

Hansen, E., Nilsson, N. H., Lithner, D., \& Lassen, C. (2013). Hazardous substances in plastic materials. Hazardous substances in plastic materials, 148.

DOI: https://www.byggemiljo.no/wp-content/uploads/2014/10/72 ta3017.pdf accessed on 17/04/2020

Hanson, A., David, T., Sabatin, A., (1992). Transport and Remediation of Subsurface Contaminants. American Chemical Society, Washington DC, USA, pp. 108-120. DOI: https://pubs.acs.org/doi/book/10.1021/bk-1992-0491 accessed on 25/06/2020

Hardy, B., Sleutel, S., Dufey, J. E., \& Cornelis, J. T. (2019). The long-term effect of biochar on soil microbial abundance, activity and community structure is overwritten by land management. Frontiers in Environmental Science, 7, 110.

Haritash, A. K., \& Kaushik, C. P. (2009). Biodegradation aspects of polycyclic aromatic hydrocarbons (PAHs): a review. Journal of hazardous materials, 169(1-3), 1-15.

Hassan, M., Liu, Y., Naidu, R., Parikh, S. J., Du, J., Qi, F., \& Willett, I. R. (2020). Influences of feedstock sources and pyrolysis temperature on the properties of biochar and functionality as adsorbents: A metaanalysis. Science of The Total Environment, 140714.

Holback, H., Yeo, Y., \& Park, K. (2011). Hydrogel swelling behavior and its biomedical applications. In Biomedical Hydrogels (pp. 3-24). Woodhead Publishing. DOI: https://doi.org/10.1533/9780857091383.1.3 accessed on 21/07/2020

He, J., \& Chen, J. P. (2014). A comprehensive review on biosorption of heavy metals by algal biomass: materials, performances, chemistry, and modeling simulation tools. Bioresource technology, 160, 6778.

Honda, M., \& Suzuki, N. (2020). Toxicities of Polycyclic Aromatic Hydrocarbons for Aquatic Animals. International Journal of Environmental Research and Public Health, 17(4), 1363.

Hou, Y., \& Gao, S. (2003). Monodisperse nickel nanoparticles prepared from a monosurfactant system and their magnetic properties. Journal of Materials Chemistry, 13(7), 1510-1512.

Houben, D., Evrard, L., \& Sonnet, P. (2013). Beneficial effects of biochar application to contaminated soils on the bioavailability of $\mathrm{Cd}, \mathrm{Pb}$ and $\mathrm{Zn}$ and the biomass production of rapeseed (Brassica napus L.). Biomass and Bioenergy, 57, 196-204.

Hu, Q., Jung, J., Chen, D., Leong, K., Song, S., Li, F., ... \& Lim, E. Y. (2020). Biochar industry to circular economy. Science of The Total Environment, 143820.

Hua, M., Zhang, S., Pan, B., Zhang, W., Lv, L., \& Zhang, Q. (2012). Heavy metal removal from water/wastewater by nanosized metal oxides: a review. Journal of hazardous materials, 211, 317-331.

Huang, Y., Anderson, M., Lyons, G. A., McRoberts, W. C., Wang, Y., McIlveen-Wright, D. R., ... \& Hewitt, N. J. (2014). Techno-economic analysis of biochar production and energy generation from poultry litter waste. Energy Procedia, 61, 714-717.

Hussain, A., Abbas, N., Arshad, F., Akram, M., Khan, Z. I., Ahmad, K., ... \& Mirzaei, F. (2013). Effects of diverse doses of Lead ( $\mathrm{Pb})$ on different growth attributes of Zea-Mays L., Agricultural Science, 4(5), 262-265.

IARC Working Group on the Evaluation of Carcinogenic Risks to Humans. (2010). Some nonheterocyclic polycyclic aromatic hydrocarbons and some related exposures. IARC Monographs on the evaluation of carcinogenic risks to humans, 92, 1-853.

Igalavithana, A. D., Kwon, E. E., Vithanage, M., Rinklebe, J., Moon, D. H., Meers, E., ... \& Ok, Y. S. (2019). Soil lead immobilization by biochars in short-term laboratory incubation studies. Environment international, 127, 190-198. 
Igwe, C. J., \& Ukaogo, P. O. (2015). Environmental effects of polycyclic aromatic hydrocarbons. Journal of Natural Sciences Research, 5(7), 117-132.

Insam, H., Gómez-Brandón, M., \& Ascher, J. (2015). Manure-based biogas fermentation residues-Friend or foe of soil fertility? Soil Biology and Biochemistry, 84, 1-14.

Inyang, M., Gao, B., Pullammanappallil, P., Ding, W., \& Zimmerman, A. R. (2010). Biochar from anaerobically digested sugarcane bagasse. Bioresource technology, 101(22), 8868-8872.

Inyang, M., Gao, B., Yao, Y., Xue, Y., Zimmerman, A. R., Pullammanappallil, P., \& Cao, X. (2012). Removal of heavy metals from aqueous solution by biochars derived from anaerobically digested biomass. Bioresource technology, 110, 50-56.

Jahirul, M. I., Rasul, M. G., Chowdhury, A. A., \& Ashwath, N. (2012). Biofuels production through biomass pyrolysis - a technological review. Energies, 5(12), 4952-5001.

Jaishankar, M., Tseten, T., Anbalagan, N., Mathew, B. B., \& Beeregowda, K. N. (2014). Toxicity, mechanism and health effects of some heavy metals. Interdisciplinary toxicology, 7(2), 60-72.

Jamnongkan, T., Wattanakornsiri, A., Wachirawongsakorn, P., \& Kaewpirom, S. (2014). Effects of crosslinking degree of poly (vinyl alcohol) hydrogel in aqueous solution: kinetics and mechanism of copper (II) adsorption. Polymer bulletin, 71(5), 1081-1100.

Jan, A. T., Azam, M., Siddiqui, K., Ali, A., Choi, I., \& Haq, Q. M. (2015). Heavy metals and human health: mechanistic insight into toxicity and counter defense system of antioxidants. International journal of molecular sciences, 16(12), 29592-29630.

Jiang, J., Xu, R. K., Jiang, T. Y., \& Li, Z. (2012). Immobilization of $\mathrm{Cu}$ (II), Pb (II) and Cd (II) by the addition of rice straw derived biochar to a simulated polluted Ultisol. Journal of hazardous materials, 229, 145-150.

Jiang, T. Y., XU, R. K., GU, T. X., \& Jiang, J. (2014). Effect of crop-straw derived biochars on Pb (II) adsorption in two variable charge soils. Journal of integrative agriculture, 13(3), 507-516.

Jindo, K., Audette, Y., Higashikawa, F. S., Silva, C. A., Akashi, K., Mastrolonardo, G., ... \& Mondini, C. (2020). Role of biochar in promoting circular economy in the agriculture sector. Part 1: A review of the biochar roles in soil N, P and K cycles. Chemical and Biological Technologies in Agriculture, 7(1), $1-12$.

Johnsen, A. R., Wick, L. Y., \& Harms, H. (2005). Principles of microbial PAH-degradation in soil. Environmental pollution, 133(1), 71-84.

Jung, K. H., Kim, J. K., Noh, J. H., Eun, J. W., Bae, H. J., Kim, M. G., ... \& Park, W. S. (2013). Characteristic molecular signature for the early detection and prediction of polycyclic aromatic hydrocarbons in rat liver. Toxicology letters, 216(1), 1-8.

Juteau, P., Bisaillon, J. G., Lépine, F., Ratheau, V., Beaudet, R., \& Villemur, R. (2003). Improving the biotreatment of hydrocarbons-contaminated soils by addition of activated sludge taken from the wastewater treatment facilities of an oil refinery. Biodegradation, 14(1), 31-40.

Kabir, S. F., Sikdar, P. P., Haque, B., Bhuiyan, M. R., Ali, A., \& Islam, M. N. (2018). Cellulose-based hydrogel materials: chemistry, properties and their prospective applications. Progress in biomaterials, 7(3), 153-174.

Kapahi, M., \& Sachdeva, S. (2019). Bioremediation Options for Heavy Metal Pollution. Journal of Health and Pollution, 9(24), 191203.

Kataki, S., Hazarika, S., \& Baruah, D. C. (2017). Investigation on by-products of bioenergy systems (anaerobic digestion and gasification) as potential crop nutrient using FTIR, XRD, SEM analysis and phyto-toxicity test. Journal of Environmental Management, 196, 201-216.

Keiluweit, M., Nico, P. S., Johnson, M. G., \& Kleber, M. (2010). Dynamic molecular structure of plant biomass-derived black carbon (biochar). Environmental science \& technology, 44(4), 1247-1253. 
Khalid, S., Shahid, M., Niazi, N. K., Murtaza, B., Bibi, I., \& Dumat, C. (2017). A comparison of technologies for remediation of heavy metal contaminated soils. Journal of Geochemical Exploration, 182, 247-268.

Khan, M. S., Zaidi, A., Wani, P. A., \& Oves, M. (2009). Role of plant growth promoting rhizobacteria in the remediation of metal contaminated soils. Environmental chemistry letters, 7(1), 1-19.

Khan, S., Waqas, M., Ding, F., Shamshad, I., Arp, H. P. H., \& Li, G. (2015). The influence of various biochars on the bioaccessibility and bioaccumulation of PAHs and potentially toxic elements to turnips (Brassica rapa L.). Journal of Hazardous Materials, 300, 243-253.

Khan, S., Waqas, M., Ding, F., Shamshad, I., Arp, H. P. H., \& Li, G. (2015). The influence of various biochars on the bioaccessibility and bioaccumulation of PAHs and potentially toxic elements to turnips (Brassica rapa L.). Journal of Hazardous Materials, 300, 243-253.

Khan, K. Y., Ali, B., Cui, X., Feng, Y., Yang, X., \& Stoffella, P. J. (2017). Impact of different feedstocks derived biochar amendment with cadmium low uptake affinity cultivar of pak choi (Brassica rapa ssb. chinensis L.) on phytoavoidation of $\mathrm{Cd}$ to reduce potential dietary toxicity. Ecotoxicology and environmental safety, 141, 129-138.

Kibra, M. G. (2008). Effects of mercury on some growth parameters of rice (Oryza sativa L.). Soil \& Environment, 27(1), 23-28.

Kim, H. S., Kim, K. R., Kim, H. J., Yoon, J. H., Yang, J. E., Ok, Y. S., ... \& Kim, K. H. (2015). Effect of biochar on heavy metal immobilization and uptake by lettuce (Lactuca sativa L.) in agricultural soil. Environmental Earth Sciences, 74(2), 1249-1259.

Kim, S., \& Sikes, H. D. (2020). Radical polymerization reactions for amplified biodetection signals. Polymer Chemistry, 11(8), 1424-1444.

Klein, M., \& Poverenov, E. (2020). Natural biopolymer-based hydrogels for use in food and agriculture. Journal of the Science of Food and Agriculture, 100(6), 2337-2347.

Kołtowski, M., \& Oleszczuk, P. (2015). Toxicity of biochars after polycyclic aromatic hydrocarbons removal by thermal treatment. Ecological Engineering, 75, 79-85.

Kołtowski, M., Hilber, I., Bucheli, T. D., \& Oleszczuk, P. (2016). Effect of steam activated biochar application to industrially contaminated soils on bioavailability of polycyclic aromatic hydrocarbons and ecotoxicity of soils. Science of the Total Environment, 566, 1023-1031.

Kong, H., He, J., Gao, Y., Han, J., \& Zhu, X. (2011). Removal of polycyclic aromatic hydrocarbons from aqueous solution on soybean stalk-based carbon. Journal of environmental quality, 40(6), 1737-1744.

Kriipsalu, M., Marques, M., Nammari, D. R., \& Hogland, W. (2007). Bio-treatment of oily sludge: The contribution of amendment material to the content of target contaminants, and the biodegradation dynamics. Journal of hazardous materials, 148(3), 616-622.

Kuppusamy, S., Thavamani, P., Venkateswarlu, K., Lee, Y. B., Naidu, R., \& Megharaj, M. (2017). Remediation approaches for polycyclic aromatic hydrocarbons (PAHs) contaminated soils: Technological constraints, emerging trends and future directions. Chemosphere, 168, 944-968.

Kwak, J. H., Islam, M. S., Wang, S., Messele, S. A., Naeth, M. A., El-Din, M. G., \& Chang, S. X. (2019). Biochar properties and lead (II) adsorption capacity depend on feedstock type, pyrolysis temperature, and steam activation. Chemosphere, 231, 393-404.

Lahori, A. H., Zhanyu, G. U. O., ZHANG, Z., Ronghua, L. I., Mahar, A., Awasthi, M. K., ... \& JIANG, S. (2017). Use of biochar as an amendment for remediation of heavy metal-contaminated soils: prospects and challenges. Pedosphere, 27(6), 991-1014.

Laird, D. A., Brown, R. C., Amonette, J. E., \& Lehmann, J. (2009). Review of the pyrolysis platform for coproducing bio-oil and biochar. Biofuels, bioproducts and biorefining, 3(5), 547-562.

Lakkireddy, K., \& Kües, U. (2017). Bulk isolation of basidiospores from wild mushrooms by electrostatic attraction with low risk of microbial contaminations. AMB Express, 7(1), 28. 
Latif, I. K., Karim, A. J., Zuki, A. B. Z., Zamri-Saad, M., Niu, J. P., \& Noordin, M. M. (2010). Pulmonary modulation of benzo [a] pyrene-induced hemato-and hepatotoxicity in broilers. Poultry science, $89(7)$, 1379-1388.

Lawal, A. T. (2017). Polycyclic aromatic hydrocarbons. A review. Cogent Environmental Science, 3(1), 1339841.

Leja, K., \& Lewandowicz, G. (2010). Polymer biodegradation and biodegradable polymers-a review. Polish Journal of Environmental Studies, 19(2).

Leng, L., \& Huang, H. (2018). An overview of the effect of pyrolysis process parameters on biochar stability. Bioresource technology, 270, 627-642.

Li, H., Qu, R., Li, C., Guo, W., Han, X., He, F., ... \& Xing, B. (2014). Selective removal of polycyclic aromatic hydrocarbons (PAHs) from soil washing effluents using biochars produced at different pyrolytic temperatures. Bioresource technology, 163, 193-198.

Li, H., Dong, X., da Silva, E. B., de Oliveira, L. M., Chen, Y., \& Ma, L. Q. (2017). Mechanisms of metal sorption by biochars: biochar characteristics and modifications. Chemosphere, 178, 466-478.

Li, X., Song, Y., Wang, F., Bian, Y., \& Jiang, X. (2019a). Combined effects of maize straw biochar and oxalic acid on the dissipation of polycyclic aromatic hydrocarbons and microbial community structures in soil: a mechanistic study. Journal of hazardous materials, 364, 325-331.

Li, X., Li, Y., Zhang, X., Zhao, X., Sun, Y., Weng, L., \& Li, Y. (2019b). Long-term effect of biochar amendment on the biodegradation of petroleum hydrocarbons in soil microbial fuel cells. Science of the Total Environment, 651, 796-806.

Li, R., Wang, J. J., Zhou, B., Awasthi, M. K., Ali, A., Zhang, Z., ... \& Mahar, A. (2016). Enhancing phosphate adsorption by $\mathrm{Mg} / \mathrm{Al}$ layered double hydroxide functionalized biochar with different $\mathrm{Mg} / \mathrm{Al}$ ratios. Science of the Total Environment, 559, 121-129.

Liu, P., Liu, W. J., Jiang, H., Chen, J. J., Li, W. W., \& Yu, H. Q. (2012). Modification of biochar derived from fast pyrolysis of biomass and its application in removal of tetracycline from aqueous solution. Bioresource Technology, 121, 235-240.

Liu, Z., Quek, A., Hoekman, S. K., \& Balasubramanian, R. (2013). Production of solid biochar fuel from waste biomass by hydrothermal carbonization. Fuel, 103, 943-949.

Liu, C., Tan, Y., Xu, K., Li, Y., Lu, C., \& Wang, P. (2014). Synthesis of poly (2-(2-methoxyethoxy) ethyl methacrylate) hydrogel using starch-based nanosphere cross-linkers. Carbohydrate polymers, 105, 270-275.

Liu, Z., \& Han, G. (2015). Production of solid fuel biochar from waste biomass by low temperature pyrolysis. Fuel, 158, 159-165.

Liu, L., Chen, P., Sun, M., Shen, G., \& Shang, G. (2015). Effect of biochar amendment on PAH dissipation and indigenous degradation bacteria in contaminated soil. Journal of Soils and Sediments, 15(2), 313322.

Liu, S., \& Li, L. (2017). Ultra-stretchable and self-healing double-network hydrogel for 3D printing and strain sensor. ACS applied materials \& interfaces, 9(31), 26429-26437.

Li., S., \& Chen, G. (2018). Using hydrogel-biochar composites for enhanced cadmium removal from aqueous media. Material Sci \& Eng, 2(6), 294-298.

Liu, P., Li, H., Liu, X., Wan, Y., Han, X., \& Zou, W. (2020). Preparation of magnetic biochar obtained from one-step pyrolysis of Salix Mongolica and investigation into adsorption behaviour of sulfadimidine sodium and norfloxacin in aqueous solution. Journal of Dispersion Science and Technology, 41(2), 214-226.

Logan, M., \& Visvanathan, C. (2019). Management strategies for anaerobic digestate of organic fraction of municipal solid waste: Current status and future prospects. Waste Management \& Research, 37(1_suppl), 27-39. 
Lu, K., Yang, X., Shen, J., Robinson, B., Huang, H., Liu, D., ... \& Wang, H. (2014). Effect of bamboo and rice straw biochars on the bioavailability of $\mathrm{Cd}, \mathrm{Cu}, \mathrm{Pb}$ and $\mathrm{Zn}$ to Sedum plumbizincicola. Agriculture, Ecosystems \& Environment, 191, 124-132.

Luch, A. (Ed.). (2005). The carcinogenic effects of polycyclic aromatic hydrocarbons. World Scientific. ISBN: 978-1-86094-417-8

Maestrini, B., Herrmann, A.M., Nannipieri, P., Schmidt, MWI, Abiven, S. (2014) Ryegrass-derived pyrogenic organic matter changes organic carbon and nitrogen mineralization in a temperate forest soil. Soil Biology and Biochemistry, 69, 291-301.

Maguyon-Detras, M. C., Migo, M. V. P., Van Hung, N., \& Gummert, M. (2020). Thermochemical Conversion of Rice Straw. In Sustainable Rice Straw Management (pp. 43-64). Springer, Cham. DOI:

https://library.oapen.org/bitstream/handle/20.500.12657/22844/1007317.pdf?sequence=1\#page=53 accessed on 12/07/2020

Mahdi, Z., Yu, Q. J., \& El Hanandeh, A. (2019). Competitive adsorption of heavy metal ions $\left(\mathrm{Pb}^{2+}\right.$, $\mathrm{Cu}^{2+}$, and $\mathrm{Ni}^{2+}$ ) onto date seed biochar: batch and fixed bed experiments. Separation Science and Technology, 54(6), 888-901.

Maity, J. P., Chen, G. S., Huang, Y. H., Sun, A. C., \& Chen, C. Y. (2019). Ecofriendly Heavy Metal Stabilization: Microbial Induced Mineral Precipitation (MIMP) and Biomineralization for Heavy Metals within the Contaminated Soil by Indigenous Bacteria. Geomicrobiology Journal, 36(7), 612-623.

Malkoc, E., \& Nuhoglu, Y. (2005). Investigations of nickel (II) removal from aqueous solutions using tea factory waste. Journal of hazardous materials, 127(1-3), 120-128.

Manyà, J. J. (2012). Pyrolysis for biochar purposes: a review to establish current knowledge gaps and research needs. Environmental science \& technology, 46(15), 7939-7954.

Maroušek, J., Vochozka, M., Plachý, J., \& Žák, J. (2017). Glory and misery of biochar. Clean Technologies and Environmental Policy, 19(2), 311-317.

Mašek, O., Brownsort, P., Cross, A., Sohi, S., (2013) Influence of production conditions on the yield and environmental stability of biochar. Fuel, 103, 151-155.

Mashitah, M. D., Azila, Y. Y., \& Bhatia, S. (2008). Biosorption of cadmium (II) ions by immobilized cells of Pycnoporus sanguineus from aqueous solution. Bioresource Technology, 99(11), 4742-4748.

Massos, A., \& Turner, A. (2017). Cadmium, lead and bromine in beached microplastics. Environmental Pollution, 227, 139-145.

Matuštík, J., Hnátková, T., \& Kočí, V. (2020). Life cycle assessment of biochar-to-soil systems: A review. Journal of Cleaner Production, 120998.

Medić, A., Lješević, M., Inui, H., Beškoski, V., Kojić, I., Stojanović, K., \& Karadžić, I. (2020). Efficient biodegradation of petroleum n-alkanes and polycyclic aromatic hydrocarbons by polyextremophilic Pseudomonas aeruginosa san ai with multidegradative capacity. RSC Advances, 10(24), 14060-14070.

Megharaj, M., \& Naidu, R. (2017). Soil and brownfield bioremediation. Microbial biotechnology, 10(5), 1244-1249.

Meng, J., Liang, S., Tao, M., Liu, X., Brookes, P. C., \& Xu, J. (2018). Chemical speciation and risk assessment of $\mathrm{Cu}$ and $\mathrm{Zn}$ in biochars derived from co-pyrolysis of pig manure with rice straw. Chemosphere, 200, 344-350.

Mohan, D., Pittman Jr, C. U., \& Steele, P. H. (2006). Pyrolysis of wood/biomass for bio-oil: a critical review. Energy \& fuels, 20(3), 848-889.

Mohamed, B. A., Ellis, N., Kim, C. S., \& Bi, X. (2017). The role of tailored biochar in increasing plant growth, and reducing bioavailability, phytotoxicity, and uptake of heavy metals in contaminated soil. Environmental Pollution, 230, 329-338. 
Mohamed, A. K., \& Mahmoud, M. E. (2020). Nanoscale Pisum sativum pods biochar encapsulated starch hydrogel: A novel nanosorbent for efficient chromium (VI) ions and naproxen drug removal. Bioresource Technology, 123263.

Möller, K., \& Müller, T. (2012). Effects of anaerobic digestion on digestate nutrient availability and crop growth: a review. Engineering in Life Sciences, 12(3), 242-257.

Montes, F., Meinen, R., Dell, C., Rotz, A., Hristov, A. N., Oh, J., ... \& Dijkstra, J. (2013). Special topicsMitigation of methane and nitrous oxide emissions from animal operations: II. A review of manure management mitigation options. Journal of animal science, 91(11), 5070-5094.

Moon, D. H., Park, J. W., Chang, Y. Y., Ok, Y. S., Lee, S. S., Ahmad, M., ... \& Baek, K. (2013). Immobilization of lead in contaminated firing range soil using biochar. Environmental Science and Pollution Research, 20(12), 8464-8471.

Moorthy, B., Chu, C., \& Carlin, D. J. (2015). Polycyclic aromatic hydrocarbons: from metabolism to lung cancer. Toxicological Sciences, 145(1), 5-15.

Mrozik, A., \& Piotrowska-Seget, Z. (2010). Bioaugmentation as a strategy for cleaning up of soils contaminated with aromatic compounds. Microbiological research, 165(5), 363-375.

Nair, N. R., Sekhar, V. C., Nampoothiri, K. M., \& Pandey, A. (2017). Biodegradation of biopolymers. In Current Developments in Biotechnology and Bioengineering (pp. 739-755).

Namkoong, W., Hwang, E. Y., Park, J. S., \& Choi, J. Y. (2002). Bioremediation of diesel-contaminated soil with composting. Environmental pollution, 119(1), 23-31.

Nie, C., Yang, X., Niazi, N. K., Xu, X., Wen, Y., Rinklebe, J., ... \& Wang, H. (2018). Impact of sugarcane bagasse-derived biochar on heavy metal availability and microbial activity: a field study. Chemosphere, 200, 274-282.

Nematshahi, N., Lahouti, M., \& Ganjeali, A. (2012). Accumulation of chromium and its effect on growth of (Allium cepa cv. Hybrid). European Journal of Experimental Biology, 2(4), 969-974.

Ni, N., Wang, F., Song, Y., Bian, Y., Shi, R., Yang, X., ... \& Jiang, X. (2018). Mechanisms of biochar reducing the bioaccumulation of PAHs in rice from soil: Degradation stimulation vs immobilization. Chemosphere, 196, 288-296.

Nie, C., Yang, X., Niazi, N. K., Xu, X., Wen, Y., Rinklebe, J., ... \& Wang, H. (2018). Impact of sugarcane bagasse-derived biochar on heavy metal availability and microbial activity: a field study. Chemosphere, 200, 274-282.

Niu, L. Q., Jia, P., Li, S. P., Kuang, J. L., He, X. X., Zhou, W. H., ... \& Li, J. T. (2015). Slash-and-char: an ancient agricultural technique holds new promise for management of soils contaminated by $\mathrm{Cd}, \mathrm{Pb}$ and Zn. Environmental pollution, 205, 333-339.

Ogbonna, C. B., Stanley, H. O., \& Abu, G. O. (2018). Effect of Liquid Digestate on Agricultural Soil-II: Microbial Population Dynamics. Appli Microbiol Open Access, 4(145), 2.

Oleszczuk, P., Hale, S. E., Lehmann, J., \& Cornelissen, G. (2012). Activated carbon and biochar amendments decrease pore-water concentrations of polycyclic aromatic hydrocarbons (PAHs) in sewage sludge. Bioresource technology, 111, 84-91.

Oleszczuk, P., \& Kołtowski, M. (2018). Changes of total and freely dissolved polycyclic aromatic hydrocarbons and toxicity of biochars treated with various aging processes. Environmental Pollution, 237, 65-73.

Oleszczuk, P., Rakowska, M., Bucheli, T. D., Godlewska, P., \& Reible, D. D. (2019). Combined effects of plant cultivation and sorbing carbon amendments on freely dissolved PAHs in contaminated soil. Environmental science \& technology, 53(9), 4860-4868.

Oliveira, F. R., Patel, A. K., Jaisi, D. P., Adhikari, S., Lu, H., \& Khanal, S. K. (2017). Environmental application of biochar: Current status and perspectives. Bioresource technology, 246, 110-122. 
Omidian, H., Rocca, J. G., \& Park, K. (2005). Advances in superporous hydrogels. Journal of controlled release, $102(1), 3-12$.

Oni, B. A., Oziegbe, O., \& Olawole, O. O. (2019). Significance of biochar application to the environment and economy. Annals of Agricultural Sciences, 64(2), 222-236.

Orcutt, D. M., \& Nilsen, E. T. (2000). The Physiology of Plants Under Stress: Soil and Biotic Factors. Wiley Inc. New York. ISBN: 0471170089 (ISBN13: 9780471170082)

Othman, H. B., Lanouguère, É., Got, P., Hlaili, A. S., \& Leboulanger, C. (2018). Structural and functional responses of coastal marine phytoplankton communities to PAH mixtures. Chemosphere, 209, 908919.

Panahi, H. K. S., Dehhaghi, M., Ok, Y. S., Nizami, A. S., Khoshnevisan, B., Mussatto, S. I., ... \& Lam, S. S. (2020). A comprehensive review of engineered biochar: production, characteristics, and environmental applications. Journal of Cleaner Production, 122462.

Panda, S. K., \& Patra, H. K. (2000). Nitrate and ammonium ions effect on the chromium toxicity in developing wheat seedlings. Proceedings of the National Academy of Sciences India. Section B, Biological Sciences, 70(1), 75-80.

Pandey, D., Daverey, A., \& Arunachalam, K. (2020). Biochar: Production, properties and emerging role as a support for enzyme immobilization. Journal of Cleaner Production, 255, 120267.

Park, J. H., Ok, Y. S., Kim, S. H., Cho, J. S., Heo, J. S., Delaune, R. D., \& Seo, D. C. (2016).

Competitive adsorption of heavy metals onto sesame straw biochar in aqueous solutions.

Chemosphere, 142, 77-83.

Patel, A.K., (2018) Land Applications of Biochar: An Emerging Area. In: Singhania R., Agarwal R., Kumar R., Sukumaran R. (eds) Waste to Wealth. Energy, Environment, and Sustainability. Springer, Singapore. https://doi.org/10.1007/978-981-10-7431-8_9

Pathan, S., \& Bose, S. (2018). Arsenic Removal Using “Green” Renewable Feedstock-Based Hydrogels: Current and Future Perspectives. ACS omega, 3(5), 5910-5917.

Patra, M., Bhowmik, N., Bandopadhyay, B., \& Sharma, A. (2004). Comparison of mercury, lead and arsenic with respect to genotoxic effects on plant systems and the development of genetic tolerance. Environmental and Experimental Botany, 52(3), 199-223.

Paunovic, O., Pap, S., Maletic, S., Taggart, M. A., Boskovic, N., \& Sekulic, M. T. (2019). Ionisable emerging pharmaceutical adsorption onto microwave functionalised biochar derived from novel lignocellulosic waste biomass. Journal of colloid and interface science, 547, 350-360.

Peng, Z., Liu, X., Chen, H., Liu, Q., \& Tang, J. (2019). Characterization of ultraviolet-modified biochar from different feedstocks for enhanced removal of hexavalent chromium from water. Water Science and Technology, 79(9), 1705-1716.

Pérez, R. M., Cabrera, G., Gómez, J. M., Abalos, A., \& Cantero, D. (2010). Combined strategy for the precipitation of heavy metals and biodegradation of petroleum in industrial wastewaters. Journal of Hazardous Materials, 182(1-3), 896-902.

Piscitelli, L., Malerba, A. D., Mezzapesa, G. N., Dumontet, S., Mondelli, D., Miano, T., \& Bruno, G. L. (2019). Potential microbial remediation of pyrene polluted soil: the role of biochar. Soil Research, 57(8), 807-813.

Pourbeyram, S., \& Mohammadi, S. (2014). Synthesis and characterization of highly stable and water dispersible hydrogel-copper nanocomposite. Journal of non-crystalline solids, 402, 58-63.

Prapagdee, S., Piyatiratitivorakul, S., Petsom, A., \& Tawinteung, N. (2014). Application of biochar for enhancing cadmium and zinc phytostabilization in Vigna radiata L. cultivation. Water, Air, \& Soil Pollution, 225(12), 2233.

Psomopoulos, C. S., Bourka, A., \& Themelis, N. J. (2009). Waste-to-energy: A review of the status and benefits in USA. Waste management, 29(5), 1718-1724. 
Public Health England (PHE). (2018). Polycyclic aromatic hydrocarbons (Benzo[a]pyrene: general information. DOI: https://www.gov.uk/government/publications/benzoapyrene-properties-incidentmanagement-and-toxicology/polycyclic-aromatic-hydrocarbons-benzoapyrene-general-information accessed on 20/07/2020

Puga, A. P., Abreu, C. A., Melo, L. C. A., \& Beesley, L. (2015). Biochar application to a contaminated soil reduces the availability and plant uptake of zinc, lead and cadmium. Journal of environmental management, 159, 86-93.

Pulleyblank, C., Cipullo, S., Campo, P., Kelleher, B., \& Coulon, F. (2019). Analytical progress and challenges for the detection of oxygenated polycyclic aromatic hydrocarbon transformation products in aqueous and soil environmental matrices: A review. Critical Reviews in Environmental Science and Technology, 49(5), 357-409.

Qayyum, S., Khan, I., Meng, K., Zhao, Y., \& Peng, C. (2020). A review on remediation technologies for heavy metals contaminated soil. Central Asian Journal of Environmental Science and Technology Innovation, 1(1), 21-29.

Qi, X., Gou, J., Chen, X., Xiao, S., Ali, I., Shang, R., ... \& Luo, X. (2020). Application of mixed bacteria-loaded biochar to enhance uranium and cadmium immobilization in a co-contaminated soil. Journal of Hazardous Materials, 401, 123823.

Qian, K., Kumar, A., Zhang, H., Bellmer, D., \& Huhnke, R. (2015). Recent advances in utilization of biochar. Renewable and Sustainable Energy Reviews, 42, 1055-1064.

Rahman, M. A., Hasegawa, H., Rahman, M. M., Rahman, M. A., \& Miah, M. A. M. (2007). Accumulation of arsenic in tissues of rice plant (Oryza sativa L.) and its distribution in fractions of rice grain. Chemosphere, 69(6), 942-948.

Rajapaksha, A. U., Chen, S. S., Tsang, D. C., Zhang, M., Vithanage, M., Mandal, S., ... \& Ok, Y. S. (2016). Engineered/designer biochar for contaminant removal/immobilization from soil and water: potential and implication of biochar modification. Chemosphere, 148, 276-291.

Rajendran, P., Muthukrishnan, J., \& Gunasekaran, P. (2003). Microbes in heavy metal remediation. Indian Journal of Experimental Biology, 41, 935-944.

Raper, E., Stephenson, T., Anderson, D. R., Fisher, R., \& Soares, A. (2018). Industrial wastewater treatment through bioaugmentation. Process Safety and Environmental Protection, 118, 178-187.

Rascio, N., \& Navari-Izzo, F. (2011). Heavy metal hyperaccumulating plants: how and why do they do it? And what makes them so interesting?Plant science, 180(2), 169-181.

Rees, F., Simonnot, M. O., \& Morel, J. L. (2014). Short-term effects of biochar on soil heavy metal mobility are controlled by intra-particle diffusion and soil $\mathrm{pH}$ increase. European Journal of Soil Science, 65(1), 149-161.

Rehman, T. U., Shah, L. A., Khattak, N. S., Khan, A., Rehman, N., \& Alam, S. (2019). Superabsorbent Hydrogels for Heavy Metal Removal. In Heavy Metal Ions Removal. IntechOpen. DOI: http://dx.doi.org/10.5772/intechopen.89350 accessed on 29/05/2020

Rombolà, A. G., Fabbri, D., Baronti, S., Vaccari, F. P., Genesio, L., \& Miglietta, F. (2019). Changes in the pattern of polycyclic aromatic hydrocarbons in soil treated with biochar from a multiyear field experiment. Chemosphere, 219, 662-670.

Sadeghi Afjeh, M., Bageri Marandi, G., \& Zohuriaan-Mehr, M. J. (2020). Hydrogel-rice husk biochar composite as an adsorbent for the removal of phenol and PNP from aqueous solutions. Separation Science and Technology, 1-16.

Sagrilo E., Jeffery S., Hoffland E., Kuyper T.W. 2015. Emission of $\mathrm{CO}_{2}$ from biochar-amended soils and implications for soil organic carbon. GCB-Bioenergy, 7:1294-1304 
Safaei, K.M., Fatemi, A., Khan, M. A., Kiefer, R., \& Jafarnia, S. (2018). Potential risk of weed outbreak by increasing biochar's application rates in slow-growth legume, lentil (Lens culinaris Medik.). Journal of the science of food and agriculture, 98(6), 2080-2088.

Sajjadi, B., Zubatiuk, T., Leszczynska, D., Leszczynski, J., \& Chen, W. Y. (2019a). Chemical activation of biochar for energy and environmental applications: a comprehensive review. Reviews in Chemical Engineering, 35(7), 777-815.

Sajjadi, B., Chen, W. Y., \& Egiebor, N. O. (2019b). A comprehensive review on physical activation of biochar for energy and environmental applications. Reviews in Chemical Engineering, 35(6), 735776.

Salem, H. M., Eweida, E. A., \& Farag, A. (2000). Heavy metals in drinking water and their environmental impact on human health. ICEHM2000, Cairo University, Egypt, 542-556.

Sall, M. L., Diaw, A. K. D., Gningue-Sall, D., Aaron, J. J., \& Aaron, J. J. (2020). Toxic heavy metals: impact on the environment and human health, and treatment with conducting organic polymers, a review. Environmental Science and Pollution Research International. 27, 29927-29942.

Sankarammal, M., Thatheyus, A., \& Ramya, D. (2014). Bioremoval of cadmium using pseudomonas fluorescens. Open J. Water Pollut. Treat, 1, 92-100.

Sanyang, L., Ghani, W. A. W. A. K., Idris, A., \& Mansor, A. (2014). Zinc Removal from Wastewater Using Hydrogel Modified Biochar. In Applied Mechanics and Materials (Vol. 625, pp. 842-846). Trans Tech Publications Ltd.

Sayara, T., Sarrà, M., \& Sánchez, A. (2010). Effects of compost stability and contaminant concentration on the bioremediation of PAHs-contaminated soil through composting. Journal of Hazardous Materials, 179(1-3), 999-1006.

Selvi, A., Rajasekar, A., Theerthagiri, J., Ananthaselvam, A., Sathishkumar, K., Madhavan, J., \& Rahman, P. K. (2019). Integrated remediation processes toward heavy metal removal/recovery from various environments-a review. Frontiers in Environmental Science, 7, 66.

Shabangu, S., Woolf, D., Fisher, E. M., Angenent, L. T., \& Lehmann, J. (2014). Techno-economic assessment of biomass slow pyrolysis into different biochar and methanol concepts. Fuel, 117, 742748.

Shackley, S., Hammond, J., Gaunt, J., \& Ibarrola, R. (2011). The feasibility and costs of biochar deployment in the UK. Carbon Management, 2(3), 335-356.

Shalla, A. H., Yaseen, Z., Bhat, M. A., Rangreez, T. A., \& Maswal, M. (2019). Recent review for removal of metal ions by hydrogels. Separation Science and Technology, 54(1), 89-100.

Sharma, D. C., \& Sharma, C. P. (1993). Chromium uptake and its effects on growth and biological yield of wheat. Cereal Research Communications, 21(4), 317-322.

Sharma, Y. C. (1995). Economic treatment of cadmium (II)-rich hazardous waste by indigenous material. Journal of colloid and interface science, 173(1), 66-70.

Sharma, P., \& Dubey, R. S. (2005). Lead toxicity in plants. Brazilian journal of plant physiology, 17(1), 35-52.

Sharma, S., Tiwari, S., Hasan, A., Saxena, V., \& Pandey, L. M. (2018). Recent advances in conventional and contemporary methods for remediation of heavy metal-contaminated soils. 3 Biotech, 8(4), 216.

Shekar, C. C., Sammaiah, D., Shasthree, T., \& Reddy, K. J. (2011). Effect of mercury on tomato growth and yield attributes. International Journal of Pharma and Bio Sciences, 2(2), B358-364.

Shen, C., Shen, Y., Wen, Y., Wang, H., \& Liu, W. (2011). Fast and highly efficient removal of dyes under alkaline conditions using magnetic chitosan-Fe (III) hydrogel. Water research, 45(16), 5200-5210.

Shen, X., Huang, D. Y., Ren, X. F., Zhu, H. H., Wang, S., Xu, C., ... \& Zhu, Q. H. (2016). Phytoavailability of $\mathrm{Cd}$ and $\mathrm{Pb}$ in crop straw biochar-amended soil is related to the heavy metal content of both biochar and soil. Journal of environmental management, 168, 245-251. 
Shi, K., Xue, J., Xiao, X., Qiao, Y., Wu, Y., \& Gao, Y. (2019). Mechanism of degrading petroleum hydrocarbons by compound marine petroleum-degrading bacteria: surface adsorption, cell uptake, and biodegradation. Energy \& Fuels, 33(11), 11373-11379.

Shinde, U. P., Yeon, B., \& Jeong, B. (2013). Recent progress of in situ formed gels for biomedical applications. Progress in polymer science, 38(3-4), 672-701.

Simate, G. S., Maledi, N., Ochieng, A., Ndlovu, S., Zhang, J., \& Walubita, L. F. (2016). Coal-based adsorbents for water and wastewater treatment. Journal of Environmental Chemical Engineering, 4(2), 2291-2312.

Singh, A., \& Ward, O. P. (2004). Biotechnology and bioremediation-an overview. In Biodegradation and bioremediation (pp. 1-17). Springer, Berlin, Heidelberg.

Singh, N., Ma, L. Q., Srivastava, M., \& Rathinasabapathi, B. (2006). Metabolic adaptations to arsenicinduced oxidative stress in Pteris vittata L and Pteris ensiformis L. Plant Science, 170(2), 274-282.

Singh, N., Gupta, V. K., Kumar, A., \& Sharma, B. (2017). Synergistic effects of heavy metals and pesticides in living systems. Frontiers in chemistry, 5, 70.

Simeng, L., \& Chen, G. (2018). Using hydrogel-biochar composites for enhanced cadmium removal from aqueous media. Material Sci \& Eng, 2(6), 294-298.

Sisto, R., Sica, E., Lombardi, M., \& Prosperi, M. (2017). Organic fraction of municipal solid waste valorisation in southern Italy: the stakeholders' contribution to a long-term strategy definition. Journal of Cleaner Production, 168, 302-310.

Smith, P., Gregory, P. J., Van Vuuren, D., Obersteiner, M., Havlík, P., Rounsevell, M., ... \& Bellarby, J. (2010). Competition for land. Philosophical Transactions of the Royal Society B: Biological Sciences, 365(1554), 2941-2957.

Sowada, J., Lemoine, L., Schön, K., Hutzler, C., Luch, A., \& Tralau, T. (2017). Toxification of polycyclic aromatic hydrocarbons by commensal bacteria from human skin. Archives of toxicology, 91(6), 23312341.

Sparks, D. L. (2005). Toxic metals in the environment: the role of surfaces. Elements, 1(4), 193-197.

Sridhar, M. B., Han, F. X., Diehl, S. V., Monts, D. L., \& Su, Y. (2007a). Monitoring the effects of arsenic and chromium accumulation in Chinese brake fern (Pteris vittata). International Journal of Remote Sensing, 28(5), 1055-1067.

Sridhar, B. M., Han, F. X., Diehl, S. V., Monts, D. L., \& Su, Y. (2007b). Spectral reflectance and leaf internal structure changes of barley plants due to phytoextraction of zinc and cadmium. International journal of remote sensing, 28(5), 1041-1054.

Srogi, K. (2007) Monitoring of environmental exposure to polycyclic aromatic hydrocarbons: a review. Environmental Chemistry Letters. 5: 169-195.

Stefaniuk, M., Oleszczuk, P., \& Różyło, K. (2017). Co-application of sewage sludge with biochar increases disappearance of polycyclic aromatic hydrocarbons from fertilized soil in long term field experiment. Science of The Total Environment, 599, 854-862.

Stegmann, P., Londo, M., \& Junginger, M. (2020). The circular bioeconomy: Its elements and role in European bioeconomy clusters. Resources, Conservation \& Recycling: X, 6, 100029.

Sunil, K. C. R., Swati, K., Bhavya, G., Nandhini, M., Veedashree, M., Prakash, H. S., ... \& Geetha, N. (2015). Streptomyces flavomacrosporus, A multi-metal tolerant potential bioremediation candidate isolated from paddy field irrigated with industrial effluents. Int J Life Sci, 3, 9-15.

Szczepaniak, Z., Czarny, J., Staninska-Pięta, J., Lisiecki, P., Zgoła-Grześkowiak, A., Cyplik, P., ... \& Glazar, K. (2016). Influence of soil contamination with PAH on microbial community dynamics and 
expression level of genes responsible for biodegradation of PAH and production of rhamnolipids. Environmental Science and Pollution Research, 23(22), 23043-23056.

Tan, X., Liu, Y., Gu, Y., Zeng, G., Wang, X., Hu, X., ... \& Yang, Z. (2015). Immobilization of Cd (II) in acid soil amended with different biochars with a long term of incubation. Environmental Science and Pollution Research, 22(16), 12597-12604.

Tambone, F., Scaglia, B., D’Imporzano, G., Schievano, A., Orzi, V., Salati, S., \& Adani, F. (2010). Assessing amendment and fertilizing properties of digestates from anaerobic digestion through a comparative study with digested sludge and compost. Chemosphere, 81(5), 577-583.

Tandey, R., Chouhan, K. B. S., Sen, K. K., Mehta, R., Dubey, A., Das, R., ... \& Mandal, V. (2020). Physiological and biochemical responses of Amaranthus cruentus to polycyclic aromatic hydrocarbon pollution caused by thermal power units. Environmental Science and Pollution Research, 27, 1479014806.

Tang, S. C., Wang, P., Yin, K., \& Lo, I. M. (2010). Synthesis and application of magnetic hydrogel for $\mathrm{Cr}$ (VI) removal from contaminated water. Environmental Engineering Science, 27(11), 947-954.

Tang, S. C., Lo, I. M., \& Mak, M. S. (2012). Comparative study of the adsorption selectivity of Cr (VI) onto cationic hydrogels with different functional groups. Water, Air, \& Soil Pollution, 223(4), 17131722.

Tang, S. C., Yan, D. Y., \& Lo, I. M. (2014). Sustainable wastewater treatment using microsized magnetic hydrogel with magnetic separation technology. Industrial \& Engineering Chemistry Research, 53(40), 15718-15724.

Tella, M., Bravin, M. N., Thuriès, L., Cazevieille, P., Chevassus-Rosset, C., Collin, B., ... \& Doelsch, E. (2016). Increased zinc and copper availability in organic waste amended soil potentially involving distinct release mechanisms. Environmental pollution, 212, 299-306.

Tendero, C., Tixier, C., Tristant, P., Desmaison, J., \& Leprince, P. (2006). Atmospheric pressure plasmas: A review. Spectrochimica Acta Part B: Atomic Spectroscopy, 61(1), 2-30.

Tesinova, P. (Ed.). (2011). Advances in Composite Materials: Analysis of Natural and Man-Made Materials. BoD-Books on Demand. Published: September $9^{\text {th }}$ 2011. ISBN: 978-953-307-449-8

Thakur, V. K., \& Thakur, M. K. (2014). Recent trends in hydrogels based on psyllium polysaccharide: a review. Journal of Cleaner Production, 82, 1-15.

Thi, N. B. D., Kumar, G., \& Lin, C. Y. (2015). An overview of food waste management in developing countries: Current status and future perspective. Journal of environmental management, 157, 220-229.

Tomczyk, A., Sokołowska, Z., \& Boguta, P. (2020). Biochar physicochemical properties: pyrolysis temperature and feedstock kind effects. Reviews in Environmental Science and Bio/Technology, 1-25.

Trejo-Hernandez, M. R., Ortiz, A., Okoh, A. I., Morales, D., \& Quintero, R. (2007). Biodegradation of heavy crude oil Maya using spent compost and sugar cane bagasse wastes. Chemosphere, 68(5), 848855.

Tripp, S. L., Pusztay, S. V., Ribbe, A. E., \& Wei, A. (2002). Self-assembly of cobalt nanoparticle rings. Journal of the American Chemical Society, 124(27), 7914-7915.

Tu, C., Wei, J., Guan, F., Liu, Y., Sun, Y., \& Luo, Y. (2020). Biochar and bacteria inoculated biochar enhanced $\mathrm{Cd}$ and $\mathrm{Cu}$ immobilization and enzymatic activity in a polluted soil. Environment International, 137, 105576.

van Grevenynghe, J., Bernard, M., Langouet, S., Le Berre, C., Fest, T., \& Fardel, O. (2005). Human CD34-positive hematopoietic stem cells constitute targets for carcinogenic polycyclic aromatic hydrocarbons. Journal of Pharmacology and Experimental Therapeutics, 314(2), 693-702.

Van Poucke, R., Egene, C. E., Allaert, S., Lebrun, M., Bourgerie, S., Morabito, D., ... \& Tack, F. M. (2020). Application of biochars and solid fraction of digestate to decrease soil solution $\mathrm{Cd}, \mathrm{Pb}$ and $\mathrm{Zn}$ 
concentrations in contaminated sandy soils. Environmental geochemistry and health, 42(6), 15891600.

van Wezel, A., Caris, I., \& Kools, S. A. (2016). Release of primary microplastics from consumer products to wastewater in The Netherlands. Environmental toxicology and chemistry, 35(7), 1627-1631.

Van Zwieten, L., Kimber, S., Morris, S., Chan, K. Y., Downie, A., Rust, J., ... \& Cowie, A. (2010). Effects of biochar from slow pyrolysis of papermill waste on agronomic performance and soil fertility. Plant and soil, 327(1-2), 235-246.

Varma, A. K., Shankar, R., \& Mondal, P. (2018). A Review on Pyrolysis of Biomass and the Impacts of Operating Conditions on Product Yield, Quality, and Upgradation. In Recent Advancements in Biofuels and Bioenergy Utilization (pp. 227-259). Springer, Singapore. https://doi.org/10.1007/978981-13-1307-3 10 accessed 12/07/2020

Varma, A. K., Thakur, L. S., Shankar, R., \& Mondal, P. (2019). Pyrolysis of wood sawdust: Effects of process parameters on products yield and characterization of products. Waste Management, 89, 224235.

Verma, A., Thakur, S., Mamba, G., Gupta, R. K., Thakur, P., \& Thakur, V. K. (2020). Graphite modified sodium alginate hydrogel composite for efficient removal of malachite green dye. International Journal of Biological Macromolecules, 148, 1130-1139.

Vernay, P., Gauthier-Moussard, C., \& Hitmi, A. (2007). Interaction of bioaccumulation of heavy metal chromium with water relation, mineral nutrition and photosynthesis in developed leaves of Lolium perenne L. Chemosphere, 68(8), 1563-1575.

Versieren, L., Evers, S., AbdElgawad, H., Asard, H., \& Smolders, E. (2017). Mixture toxicity of copper, cadmium, and zinc to barley seedlings is not explained by antioxidant and oxidative stress biomarkers. Environmental toxicology and chemistry, 36(1), 220-230.

Vijayaraghavan, K., \& Yun, Y. S. (2008). Bacterial biosorbents and biosorption. Biotechnology advances, 26(3), 266-291.

Walsh, J. J., Jones, D. L., Edwards-Jones, G., \& Williams, A. P. (2012). Replacing inorganic fertilizer with anaerobic digestate may maintain agricultural productivity at less environmental cost. Journal of Plant Nutrition and Soil Science, 175(6), 840-845.

Wan, Y., Luo, S., Chen, J., Xiao, X., Chen, L., Zeng, G., ... \& He, Y. (2012). Effect of endophyte-infection on growth parameters and Cd-induced phytotoxicity of Cd-hyperaccumulator Solanum nigrum L. Chemosphere, 89(6), 743-750.

Wang, M., Zou, J., Duan, X., Jiang, W., \& Liu, D. (2007). Cadmium accumulation and its effects on metal uptake in maize (Zea mays L.). Bioresource Technology, 98(1), 82-88.

Wang, H., Wei, J., \& Simon, G. P. (2014). Response to osmotic pressure versus swelling pressure: comment on "bifunctional polymer hydrogel layers as forward osmosis draw agents for continuous production of fresh water using solar energy”. Environmental science \& technology, 48(7), 42144215.

Wang, T., Sun, H., Ren, X., Li, B., \& Mao, H. (2017). Evaluation of biochars from different stock materials as carriers of bacterial strain for remediation of heavy metal-contaminated soil. Scientific Reports, 7(1), 1-10.

Wang, B., Gao, B., \& Fang, J. (2017). Recent advances in engineered biochar productions and applications. Critical reviews in environmental science and technology, 47(22), 2158-2207.

Wang, M., Zhu, Y., Cheng, L., Andserson, B., Zhao, X., Wang, D., \& Ding, A. (2018). Review on utilization of biochar for metal-contaminated soil and sediment remediation. Journal of Environmental Sciences, 63, 156-173. 
Wang, J., \& Wang, S. (2019). Preparation, modification and environmental application of biochar: a review. Journal of Cleaner Production, 227, 1002-1022.

Wang, L., Ok, Y. S., Tsang, D. C., Alessi, D. S., Rinklebe, J., Wang, H., ... \& Hou, D. (2020a). New trends in biochar pyrolysis and modification strategies: feedstock, pyrolysis conditions, sustainability concerns and implications for soil amendment. Soil Use and Management. 36(3), 358-396.

Wang, X., Guo, Z., Hu, Z., \& Zhang, J. (2020b). Recent advances in biochar application for water and wastewater treatment: a review. PeerJ, 8, e9164.

Wassenberg, D. M., \& Di Giulio, R. T. (2004). Synergistic embryotoxicity of polycyclic aromatic hydrocarbon aryl hydrocarbon receptor agonists with cytochrome P4501A inhibitors in Fundulus heteroclitus. Environmental health perspectives, 112(17), 1658-1664.

White, P. A. (2002). The genotoxicity of priority polycyclic aromatic hydrocarbons in complex mixtures. Mutation Research/Genetic Toxicology and Environmental Mutagenesis, 515(1-2), 85-98.

Whitfield, J. B., Dy, V., McQuilty, R., Zhu, G., Heath, A. C., Montgomery, G. W., \& Martin, N. G. (2010). Genetic effects on toxic and essential elements in humans: arsenic, cadmium, copper, lead, mercury, selenium, and zinc in erythrocytes. Environmental health perspectives, 118(6), 776-782.

Williams, P. T., \& Besler, S. (1993). The pyrolysis of rice husks in a thermogravimetric analyser and static batch reactor. Fuel, 72(2), 151-159.

Wu, G., Kang, H., Zhang, X., Shao, H., Chu, L., \& Ruan, C. (2010). A critical review on the bio-removal of hazardous heavy metals from contaminated soils: issues, progress, eco-environmental concerns and opportunities. Journal of Hazardous Materials, 174(1-3), 1-8.

Wu, B., Yan, D. Y., Khan, M., Zhang, Z., \& Lo, I. M. (2017). Application of magnetic hydrogel for anionic pollutants removal from wastewater with adsorbent regeneration and reuse. Journal of Hazardous, Toxic, and Radioactive Waste, 21(1), 04016008.

Wu, H., Feng, Q., Yang, H., Alam, E., Gao, B., \& Gu, D. (2017). Modified biochar supported Ag/Fe nanoparticles used for removal of cephalexin in solution: Characterization, kinetics and mechanisms. Colloids and Surfaces A: Physicochemical and Engineering Aspects, 517, 63-71.

Wu, M. T., Lin, P. C., Pan, C. H., \& Peng, C. Y. (2019). Risk assessment of personal exposure to polycyclic aromatic hydrocarbons and aldehydes in three commercial cooking workplaces. Scientific reports, 9(1), 1-11.

Wu, Z., Chen, X., Yuan, B., \& Fu, M. L. (2020). A facile foaming-polymerization strategy to prepare 3D MnO2 modified biochar-based porous hydrogels for efficient removal of $\mathrm{Cd}$ (II) and $\mathrm{Pb}$ (II). Chemosphere, 239, 124745.

Xiao, L., Feng, L., Yuan, G., \& Wei, J. (2020). Low-cost field production of biochars and their properties. Environmental geochemistry and health, 42(6), 1569-1578.

Xiang, W., Zhang, X., Chen, K., Fang, J., He, F., Hu, X., ... \& Gao, B. (2020). Enhanced adsorption performance and governing mechanisms of ball-milled biochar for the removal of volatile organic compounds (VOCs). Chemical Engineering Journal, 385, 123842.

Xie, T., Reddy, K. R., Wang, C., Yargicoglu, E., \& Spokas, K. (2015). Characteristics and applications of biochar for environmental remediation: a review. Critical Reviews in Environmental Science and Technology, 45(9), 939-969.

Xiong, B., Zhang, Y., Hou, Y., Arp, H. P. H., Reid, B. J., \& Cai, C. (2017). Enhanced biodegradation of PAHs in historically contaminated soil by M. gilvum inoculated biochar. Chemosphere, 182, 316324. 
Xu, W., Huang, L. B., Wong, M. C., Chen, L., Bai, G., \& Hao, J. (2017). Environmentally friendly hydrogel-based triboelectric nanogenerators for versatile energy harvesting and self-powered sensors. Advanced Energy Materials, 7(1), 1601529.

Xu, H. Y., Ge, J. L., Zhang, L. L., Zhang, C., Jin, R., \& Wang, X. H. (2020). A Dibenz [a, h] AnthraceneDegrading Strain Amycolatopsis sp. Y1-2 from Soils in the Coal Mining Areas. Polycyclic Aromatic Compounds, 40(1), 166-178.

Yakimov, M. M., Timmis, K. N., \& Golyshin, P. N. (2007). Obligate oil-degrading marine bacteria. Current opinion in biotechnology, 18(3), 257-266.

Yan, H., Dai, J., Yang, Z., Yang, H., \& Cheng, R. (2011). Enhanced and selective adsorption of copper (II) ions on surface carboxymethylated chitosan hydrogel beads. Chemical Engineering Journal, 174(2-3), 586-594.

Yang, X., Liu, J., McGrouther, K., Huang, H., Lu, K., Guo, X., ... \& Wang, H. (2016). Effect of biochar on the extractability of heavy metals $(\mathrm{Cd}, \mathrm{Cu}, \mathrm{Pb}$, and $\mathrm{Zn})$ and enzyme activity in soil. Environmental Science and Pollution Research, 23(2), 974-984.

Yang, X., Lu, K., McGrouther, K., Che, L., Hu, G., Wang, Q., ... \& Wang, H. (2017). Bioavailability of $\mathrm{Cd}$ and $\mathrm{Zn}$ in soils treated with biochars derived from tobacco stalk and dead pigs. Journal of soils and sediments, 17(3), 751-762.

Yang, X., Zhang, S., Ju, M., \& Liu, L. (2019). Preparation and modification of biochar materials and their application in soil remediation. Applied Sciences, 9(7), 1365.

Yin, Z., Liu, Y., Liu, S., Jiang, L., Tan, X., Zeng, G., ... \& Fang, Y. (2018). Activated magnetic biochar by one-step synthesis: Enhanced adsorption and coadsorption for 17ß-estradiol and copper. Science of the Total Environment, 639, 1530-1542.

Yourtchi, M. S., \& Bayat, H. R. (2013). Effect of cadmium toxicity on growth, cadmium accumulation and macronutrient content of durum wheat (Dena CV.). International Journal of Agriculture and Crop Sciences (IJACS), 6(15), 1099-1103.

Zbair, M., Ahsaine, H.A., Anfar, Z. 2018. Porous carbon by microwave assisted pyrolysis: An effective and low-cost adsorbent for sulfamethoxazole adsorption and optimization using response surface methodology. J Cleaner Production, 202, 571-581

Zeng, X., Xiao, Z., Zhang, G., Wang, A., Li, Z., Liu, Y., ... \& Zou, D. (2018). Speciation and bioavailability of heavy metals in pyrolytic biochar of swine and goat manures. Journal of Analytical and Applied Pyrolysis, 132, 82-93.

Zhan, F., Zeng, W., Yuan, X., Li, B., Li, T., Zu, Y., ... \& Li, Y. (2019). Field experiment on the effects of sepiolite and biochar on the remediation of $\mathrm{Cd}$-and $\mathrm{Pb}$-polluted farmlands around a $\mathrm{Pb}-\mathrm{Zn}$ mine in Yunnan Province, China. Environmental Science and Pollution Research, 26(8), 7743-7751.

Zhang, M., Gao, B., Yao, Y., Xue, Y., \& Inyang, M. (2012). Synthesis of porous MgO-biochar nanocomposites for removal of phosphate and nitrate from aqueous solutions. Chemical Engineering Journal, 210, 26-32.

Zhang, Z., Solaiman, Z. M., Meney, K., Murphy, D. V., \& Rengel, Z. (2013). Biochars immobilize soil cadmium, but do not improve growth of emergent wetland species Juncus subsecundus in cadmiumcontaminated soil. Journal of Soils and Sediments, 13(1), 140-151.

Zhang, X., Wang, H., He, L., Lu, K., Sarmah, A., Li, J., ... \& Huang, H. (2013). Using biochar for remediation of soils contaminated with heavy metals and organic pollutants. Environmental Science and Pollution Research, 20(12), 8472-8483.

Zhang, G., Guo, X., Zhu, Y., Liu, X., Han, Z., Sun, K., ... \& Han, L. (2018). The effects of different biochars on microbial quantity, microbial community shift, enzyme activity, and biodegradation of polycyclic aromatic hydrocarbons in soil. Geoderma, 328, 100-108. 
Zhang, C., Luo, Y., Zhong, R., Law, P. T., Boon, S. S., Chen, Z., ... \& Chan, P. K. (2019). Role of polycyclic aromatic hydrocarbons as a co-factor in human papillomavirus-mediated carcinogenesis. BMC cancer, 19(1), 138.

Zhang, G., He, L., Guo, X., Han, Z., Ji, L., He, Q., ... \& Sun, K. (2020). Mechanism of biochar as a biostimulation strategy to remove polycyclic aromatic hydrocarbons from heavily contaminated soil in a coking plant. Geoderma, 375, 114497.

Zhang, M., Yin, Q., Ji, X., Wang, F., Gao, X., \& Zhao, M. (2020). High and fast adsorption of Cd (ii) and $\mathrm{Pb}$ (ii) ions from aqueous solutions by a waste biomass based hydrogel. Scientific reports, 10(1), $1-13$.

Zhang, W., Song, J., He, Q., Wang, H., Lyu, W., Feng, H., ... \& Chen, L. (2020). Novel pectin based composite hydrogel derived from grapefruit peel for enhanced $\mathrm{Cu}$ (II) removal. Journal of hazardous materials, 384, 121445.

Zhao, L., Cao, X., Mašek, O., \& Zimmerman, A. (2013). Heterogeneity of biochar properties as a function of feedstock sources and production temperatures. Journal of hazardous materials, 256, 1-9.

Zhao, T., Zhang, K., Chen, J., Shi, X., Li, X., Ma, Y., ... \& Xu, S. (2019). Changes in heavy metal mobility and availability in contaminated wet-land soil remediated using lignin-based poly (acrylic acid). Journal of hazardous materials, 368, 459-467.

Zheng, R. L., Cai, C., Liang, J. H., Huang, Q., Chen, Z., Huang, Y. Z., ... \& Sun, G. X. (2012). The effects of biochars from rice residue on the formation of iron plaque and the accumulation of $\mathrm{Cd}, \mathrm{Zn}, \mathrm{Pb}, \mathrm{As}$ in rice (Oryza sativa L.) seedlings. Chemosphere, 89(7), 856-862.

Zheng, R., Chen, Z., Cai, C., Tie, B., Liu, X., Reid, B. J., ... \& Baltrėnaite, E. (2015). Mitigating heavy metal accumulation into rice (Oryza sativa L.) using biochar amendment-a field experiment in Hunan, China. Environmental Science and Pollution Research, 22(14), 11097-11108.

Zhou, J., Li, J., Du, X., \& Xu, B. (2017). Supramolecular biofunctional materials. Biomaterials, 129, 127.

Zhou, N., Wang, Y., Huang, L., Yu, J., Chen, H., Tang, J., ... \& Zhou, Z. (2019). In situ modification provided by a novel wet pyrolysis system to enhance surface properties of biochar for lead immobilization. Colloids and Surfaces A: Physicochemical and Engineering Aspects, 570, 39-47.

Zhu, Q., Wu, J., Wang, L., Yang, G., \& Zhang, X. (2015). Effect of biochar on heavy metal speciation of paddy soil. Water, Air, \& Soil Pollution, 226(12), 429.

Zornoza, R., Moreno-Barriga, F., Acosta, J. A., Muñoz, M. A., \& Faz, A. (2016). Stability, nutrient availability and hydrophobicity of biochars derived from manure, crop residues, and municipal solid waste for their use as soil amendments. Chemosphere, 144, 122-130. 